\title{
SEGURO RURAL NO BRASIL: EVOLUÇÃO, ALTERNATIVAS E SUGESTÕES
}

\section{LUIZ CLÁUDIO CAFFAGNI}

\begin{abstract}
Dissertação apresentada à Escola Superior de Agricultura "Luiz de Queiroz", Universidade de São Paulo, para obtenção do título de Mestre em Ciências, Área de Concentração: Economia Aplicada.
\end{abstract}

\author{
PIRACICABA \\ Estado de São Paulo - Brasil
}

Fevereiro de 1998 
Dados Internacionais de Catalogaçāo na Publicação (CIP) DIVISÃo DE BIBLIOTECA E DOCUMENTAÇÃo - Campus "Luiz de Queiroz"/USP

Caffagni, Luiz Cláudio

Seguro rural no Brasil : evolução, alternativas e sugestōes / Luiz Cláudio Caffagni. - . Piracicaba , 1998.

173 p. : il.

Dissertação (mestrado) - - Escola Superior de Agricultura Luiz de Queiroz, 1998. Bibliografia.

1. Mercado futuros 2. Politica agricola 3. Seguro rural 1. Título

CDD 338.13

332.645 


\title{
SEGURO RURAL NO BRASIL: EVOLUÇÃO, ALTERNATIVAS E SUGESTÕES
}

\section{LUIZ CLÁUDIO CAFFAGNI}

\author{
Engenheiro Agrônomo
}

Orientador: Prof. Dr. Pedro Valentim Marques

\begin{abstract}
Dissertação apresentada à Escola Superior de Agricultura "Luiz de Queiroz", Universidade de São Paulo, para obtenção do título de Mestre em Ciências, Área de Concentração: Economia Aplicada.
\end{abstract}

\author{
PIRACICABA \\ Estado de São Paulo - Brasil
}

Fevereiro de 1998 


\section{SEGURO RURAL NO BRASIL: EVOLUÇÃO, ALTERNATIVAS E SUGESTÕES}

LUIZ CLÁUDIO CAFFAGNI

Aprovada em: 24.04.1998

Comissão julgadora:

Prof. Dr. Pedro Valentim Marques

Prof. Dr. Geraldo Sant'Ana de Camargo Barros

Prof. Dr. Aércio dos Santos Cunha
Esalq/USP

Esalq/USP

UNB/DF

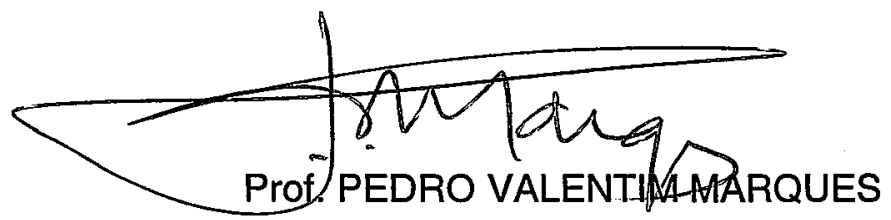

Orientador 
À Bia

Maior incentivadora desse trabalho 


\section{AGRADECIMENTOS}

Ao Prof. Pedro Valentim Marques, mais que um orientador, um amigo de todos os momentos. Por sua constante dedicação, apoio e orientação em minha vida acadêmica e profissional.

Ao Prof. Geraldo Sant'Ana de Camargo Barros, por sua decisiva contribuição em todas as fases desse trabalho.

À Profa. Mirian Rumenos Piedade Bacchi, pela atenção pacienciosa e sugestões dispensadas a esse trabalho.

Ao Prof. Adriano J. B. V. Azevedo-Filho, pelas freqüentes opiniões e idéias que auxiliaram no conteúdo da dissertação.

Ao Prof. Marcos Sawaya Jank, pelas valiosas sugestões que apontaram o direcionamento inicial do trabalho.

Ao caro amigo Eduardo Luis Leão de Sousa, companheiro de debates e reflexões, por sua influência sempre positiva na condução desse e de outros trabalhos.

Ao Dr. Roberto G. da Rocha Azevedo, da Gerenseg, por sua permanente atenção e informações sobre seguros rurais.

Ao Dr. Luiz Antônio Rossetti, do Proagro, pelo fornecimento de dados, materiais e relevantes informações.

Ao Dr. João Martini Neto, Sr. Sergio Luiz Finochchiaro, Sr. Carlos Eduardo C. Rodrigues e Sr. Jaime Alves, da Cosesp, pelas importantes reuniões e valiosas informações fornecidas para pesquisa. 
Ao amigo Roberto Ricardo Barbosa Machado, Bob, pela sua atenção e esforço em contatar importantes agentes do seguro rural brasileiro.

Aos profissionais da Bolsa de Mercadorias \& Futuros, especialmente da área agrícola, pelas inestimáveis contribuições técnicas na área de comercialização e mercados futuros.

Aos colegas do Centro de Estudos Avançados em Economia Aplicada, pelo contínuo incentivo, mesmo nas ocasiões mais difíceis.

Aos Professores, Funcionários e Colegas do Departamento de Economia e Sociologia Rural que o marcam com elevado nível acadêmico e ético, à altura da instituição que representam.

Aos meus pais Holar e Maria José pelo contínuo sacrifício e incentivo; aos meus irmãos e cunhados e a D. Marianna, pelo apoio e amizade de sempre. 


\section{SUMÁRIO}

Página

LISTA DE FIGURAS

ix

LISTA DE TABELAS

$\underline{x}$

RESUMO

xii

SUMMARY XV

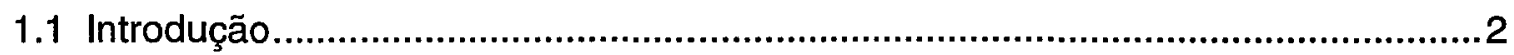

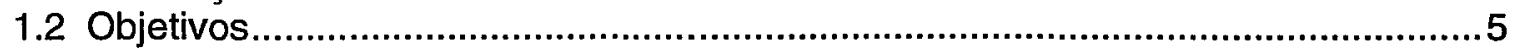

2 RISCOS $\quad 7$

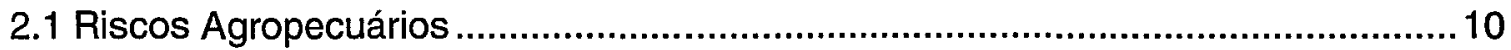

2.1.1 Riscos da Propriedade Agropecuária ............................................................11

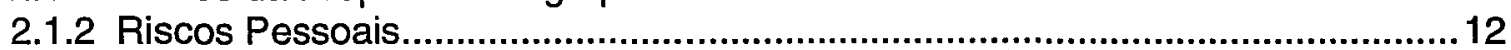

2.2 Riscos Relacionados à Renda do Produtor Rural .............................................. 12

2.2.1 Incertezas Relacionadas a Oscilações de Preços...................................................14

2.2.2 Incertezas Relacionadas a Oscilações no Volume de Produção............................17

2.3 Administração de Riscos...........................................................................................19

3 A ATIVIDADE SEGURADORA E SUAS ORGANIZACÕ̃ES 22

3.1 As Organizações de Seguros Agropecuários.......................................................27

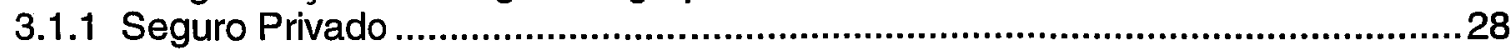

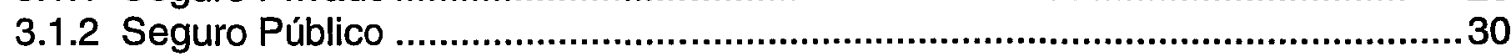



3.2 Medidas Usuais de Desempenho da Atividade Seguradora...................................33 
4.1 Histórico. 40

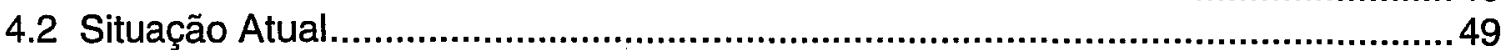

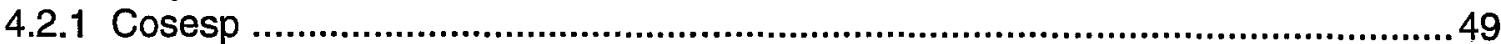

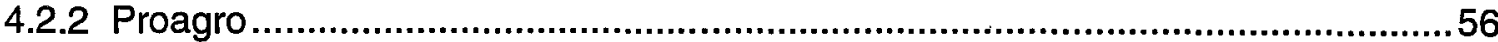



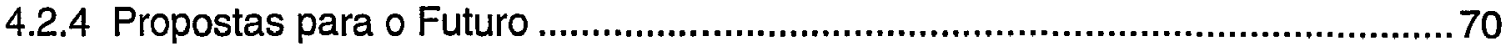

5 SEGURO RURAL NOS EUA $\quad 76$

5.1 Seguro Multi-Risco de Safras (Multi-Peril) ...........................................................79

5.1.1 Seguro Multi-Risco Genuíno (Straight Multi-Peril - APH) .................................. 80

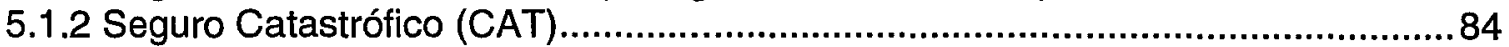

5.1.3 Cobertura de Receita da Safra (Crop Revenue Coverage - CRC) …..................8 85

5.1.4 Proteção de Receita (Income Protection - IP) ...................................................90

5.1.5 Plano de Risco Grupal (Group Risk Plan - GRP) ..........................................92

5.2 Seguro contra Granizo - Companhias Privadas ..................................................9. 94

6 MODELOS ALTERNATIVOS $\quad 95$

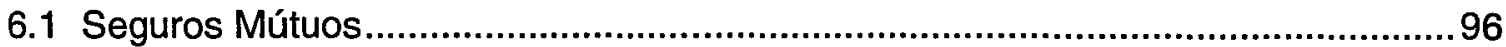

6.1.1 Cooperativa Agropecuária Batavo Ltda.......................................................97

6.1.2 Cooperativa Agrária Mista Entre Rios Ltda. .................................................. 100

6.1.3 Associação dos Fumicultores do Brasil - Afubra ...........................................101

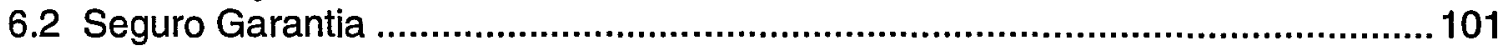

6.3 Seguros Rurais Utilizando Mercados Futuros ..................................................112

6.3.1 Seguro de Opções de Produtividade nos EUA..............................................116

6.3.2 Modelo Hedging-Griffo Corretora de Mercadorias..........................................121

7 MATERIAL E MÉTODOS $\quad 125$ 


\section{LISTA DE FIGURAS}

página

Figura 1. Classificação llustrativa (não-exaustiva) dos Riscos Agropecuários ............. 10

Figura 2. Política de Estabilização de Preços do Governo Brasileiro ............................16

Figura 3. Análise das perdas decorrentes de granizo na França entre 1888 a 1932 ...35

Figura 4. Curva de distribuição de freqüência da sinistralidade ...................................35

Figura 5. Índice Indenização/Importância Segurada ou prêmio líqüido ..........................36

Figura 6. Curva de distribuição de freqüência do Índice $\mathrm{l} / \mathrm{IS}$ ou prêmio líquido.............37

Figura 7. Índice Indenizações/Importância Segurada ou prêmio líqüido, com a

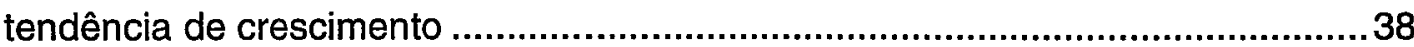

Figura 8. Índices Sinistro/Prêmio (sinistralidade) da Cosesp, entre ciclos agrícolas de $78 / 79$ e $96 / 97$ 50

Figura 9. Seguros agrícolas realizados na Cosesp, entre os ciclos agrícolas 78/79 e 96/97

Figura 10. Classificação dos Principais Programas de Seguros Agrícolas NorteAmericanos.

Figura 11. Fluxo operacional de venda antecipada ou "soja verde" e troca de insumo por produto ou "escambo" 103

Figura 12. Fluxo operacional do Certificado de Mercadorias com Emissão Garantida (CMG) 106

Figura 13. Fluxo operacional da Cédula de Produto Rural (CPR). 107

Figura 14. Tipos de agentes e contratos dos mercados de opções 114 


\section{LISTA DE TABELAS}

Página

Tabela 1. Estratégias adotadas para administração de riscos, EUA (1993)..................19

Tabela 2. Limites Técnicos das Companhias de Seguros, 1995 e 1996 ......................69

Tabela 3. Evolução do Seguro Multi-Risco Genuíno, de 1990 a 1996 ..........................83





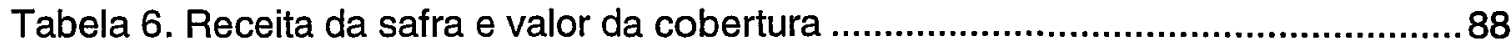

Tabela 7. Mínimo de garantia, receita da safra e valor da cobertura ..........................91

Tabela 8. Principais diferenças entre os cinco programas do Seguro de Risco Múltiplo93

Tabela 9. Cálculos das Indenizações de Soja, safra 96/97 .........................................99

Tabela 10. Seguro agrícola da Cooperativa Agropecuária Batavo, 92/93 a 96/97 .....100

Tabela 11. Probabilidade de Quebra de Safra de Soja por Estado, 1984/85

a $1993 / 94$

Tabela 12. Taxas de Risco para Soja em Diferentes Níveis de Cobertura.................111

Tabela 13. Simulação de Resultados com Contratos de Opções de Produtividade ... 120

Tabela 14. Cobertura ao se Utilizarem Recursos Próprios. ....................................... 133

Tabela 15. Cobertura ao se Utilizarem Recursos de Crédito Rural............................. 134

Tabela 16. Cobertura ao se Utilizar Adiantamento de Recursos através de um Contrato

a Termo.

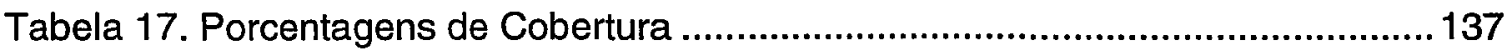

Tabela 18. Porcentagens de Prêmios........................................................................ 138

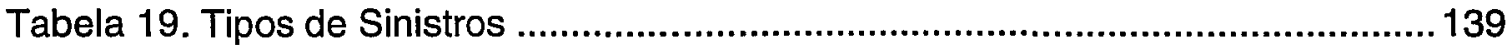

Tabela 20. Papel do Proagro e das Seguradoras ...................................................... 140

Tabela 21... Responsabilidades das Resseguradoras ............................................ 142

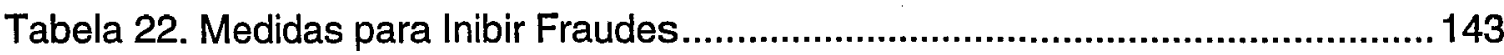

Tabela 23. Implementação de Sociedades de Seguros Mútuos ou Cooperativas...... 145

Tabela 24. Constituição de um Fundo de Estabilidade ............................................... 146

Tabela 25. Diminuição de Riscos Utilizando Mercado Futuros e de Opções .............. 147

Tabela 26. Necessidade de Intervenção Governamental.......................................... 148 
Tabela 27. Seguro Acoplado à CPR 149

Tabela 28. Desempenho Não-Satisfatório dos Seguros Rurais 150

Tabela 29. O que Seria Necessário para o Desenvolvimento do Mercado Segurador151 


\title{
SEGURO RURAL NO BRASIL: EVOLUÇÃO, ALTERNATIVAS E SUGESTÕES
}

\author{
Autor: LUIZ CLÁUDIO CAFFAGNI \\ Orientador: Prof. Dr. PEDRO VALENTIM MARQUES
}

\section{RESUMO}

Nos últimos anos, tem-se observado o desenvolvimento, com maior intensidade, de instrumentos governamentais e privados para o fornecimento de recursos e a estabilização de preços ao setor de produção, como Cédula de Produto Rural (CPR), opções de venda e mercados futuros e de opções. Entretanto, no setor de seguros rurais, notam-se uma redução de utilização por parte de produtores e uma dificuldade em se operacionalizarem novos produtos. O objetivo do trabalho foi, então, analisar as recentes propostas e colher sugestões do agribusiness para 0 desenvolvimento de produtos e ações que visem a elevar a atratividade dos seguros rurais brasileiros.

No Brasil, os seguros rurais iniciaram-se em 1938 no Estado de São Paulo, através da Secretaria da Agricultura Estadual, protegendo a cultura do algodão contra a ocorrência de granizo. Em 1939, foi criado o Instituto de Resseguros do Brasil (IRB), que seria responsável pelas operações de resseguros de todo o mercado nacional, atuando como monopólio. Apenas em 1954 instituíram-se e se disciplinaram os seguros agrícolas e pecuários no Brasil, dando competência ao IRB no desenvolvimento de estudos para a criação dos seguros agropecuários. Até então, apenas o Estado de São Paulo vinha atuando no setor. 
A modernização da legislação veio em 1966 com o Decreto-Lei № 73 e permanece até hoje regendo o setor de seguros rurais brasileiro. Atualmente, em 1998, existem alguns Projetos de Lei em tramitação na Câmara dos Deputados e no Senado que visam a adaptar o mercado segurador aos tempos de internacionalização e competição global.

Reviram-se a situação e o funcionamento do IRB, do Programa de Garantia da Atividade Agropecuária (Proagro) e da Companhia de Seguros do Estado de São Paulo (Cosesp), responsáveis em grande parte pelas operações de seguros rurais nacionais.

Nos EUA, através da investigação das modalidades de seguros atuais, detectou-se uma crescente tendência de substituição do seguro de produção por um seguro de renda. Ou seja, algumas modalidades de seguros desenvolvidas a partir de 1995 podem garantir, além da produção esperada, um preço esperado, com a utilização de mercados futuros e de opções.

Foram investigados alguns modelos alternativos que estão sendo utilizados e desenvolvidos no Brasil, como os seguros fornecidos por cooperativas mútuas e o seguro garantia para operações a termo com adiantamento de recursos, e nos EUA, como o seguro de opções de produtividade. Também foi apresentada uma proposta de seguro com a utilização do mercado de opções no Brasil.

Com o objetivo de levantar as opiniões e sugestões de agentes ligados aos setores de produção, comercialização, financeiro, processamento e seguros, foi realizada uma pesquisa dirigida, que, juntamente com as investigações posteriores, permitiram as seguintes conclusões e sugestões:

- Uma grande modificação no seguro rural brasileiro seria o desenvolvimento de uma modalidade que garantisse a receita do produtor, podendo ser operacionalizado através dos mercados de opções no Brasil. 
- Um seguro rural acoplado à CPR poderia diminuir a taxa de aval cobrada pelo banco, mas, para ser realizado com menor risco, deverá ser travado no mercado de opções.

- O Proagro deve se reestuturar, através do treinamento de inspetores, rigor na apuração de fraudes, desvincular suas operações ao crédito rural etc.

- As cooperativas de fundos mútuos devem ser incentivadas, desde que possuam algumas salvaguardas de diminuição de riscos, como resseguro, limite de cobertura, distribuição de riscos etc.

- Um fundo de estabilidade para garantia do sistema de seguros na ocorrência de catástrofes deve ser sólido e se constituir de uma porcentagem dos tributos pagos pelo setor rural e de outras fontes de recursos. 


\title{
CROP INSURANCE IN BRAZIL: HISTORY, ALTERNATIVES AND SUGGESTIONS
}

\author{
Author: LUIZ CLÁUDIO CAFFAGNI \\ Adviser: Prof. Dr. PEDRO VALENTIM MARQUES
}

\section{SUMMARY}

Recent years have increasingly seen the creation-by both government and the private sector-of instruments to provide resources to agricultural production and to ensure price stability, such as the Cédula de Produto Rural-CPR [Rural Product Note], sell options, and futures and options markets. As regards crop insurance, however, its use by producers has declined and it has become difficult to make new prodụcts operational. The purpose of this research project, then, was to analyze recent proposals and to elicit suggestions from the agribusiness sector for the development of products and initiatives aimed at making crop insurance more attractive in Brazil.

In Brazil, crop insurance first became available in the State of São Paulo in 1938, through the State Agricultural Department, offering cotton farmers protection against hailstorms. In 1939, legislation was passed creating the Brazilian Reinsurance Institute-IRB as an umbrella for all reinsurance operations in Brazil; it acted as a monopoly. Only in 1954 were crop insurance programs for crops and livestock created and regulated in Brazil, with IRB being responsible for studies leading to the creation of crop insurance programs. Up to that time, only the State of São Paulo was active in this area.

That legislation, as updated in 1966 by Decree-law № 73, still governs Brazilian crop insurance. Bills are currently under discussion in the Chamber of Deputies 
and the Senate to adapt the insurance market to internationalization and global competition.

The present work reviews the situation and operations of the Brazilian Crop Insurance Institute, the Programa de Garantia da Atividade Agropecuária-Proagro [a crop and livestock support program], and Cosesp, the São Paulo State Insurance Agency, who, together, account for a major share of crop insurance programs in Brazil.

A review of the types of insurance current in the United States shows a growing trend towards substituting income insurance for production insurance. Since 1995, some types of insurance may guarantee an expected price in addition to an expected production through the utilization of futures and options markets.

We have studied some alternative models currently in use, developed in Brazil, such as the insurance offered by mutual cooperatives and the insurance guaranteeing futures transactions, for which funds are advanced, and in the United States, such as productivity options insurance.

To find out the thinking of and elicit suggestions from the agents connected with production, marketing, financial, processing, and insurance sectors, we carried out a directed survey whose results, complemented by subsequent research, led to the following conclusions and suggestions:

- A substantial modification of the Brazilian crop insurance model would be the development of an insurance type providing the producer with an income guarantee, which could become operational through the options markets in Brazil.

- A crop insurance coupled with the CPR could lower the guarantee rate charged by the bank; to ensure lower risks, it should be contracted on the options market. 
- The Proagro should be overhauled through the training of inspectors, more rigorous fraud investigation, the unlinking of its operations from farm credit programs, etc.

- Mutual fund cooperatives should be encouraged, provided they adopt some safeguards to lower risks, such as reinsurance, coverage limits, risk sharing, etc.

- A stability fund to shore up the insurance system in case of disasters should be solid and constituted by a percentage of the taxes paid by the farm sector and by funds from other sources. 
1 INTRODUÇÃO E OBJETIVOS 


\section{INTRODUÇÃO E OBJETIVOS}

Nos últimos anos tem-se observado o desenvolvimento, em maior intensidade, de instrumentos governamentais e privados para o fornecimento de recursos e estabilização de preços ao setor de produção, como Cédula de Produto Rural (CPR), opções de venda e mercados futuros e de opções. Entretanto, no setor de seguros rurais nota-se uma redução de utilização por parte de produtores e uma dificuldade em se operacionalizar novos produtos.

No caso dos produtores rurais, pode-se perceber uma significativa diminuição na contratação de seguros rurais para proteção de seus empreendimentos, elevando a exposição do capital investido aos riscos da natureza, como secas, excesso de chuvas etc. Destacam-se a importância e a urgência em se formularem sugestões para esses problemas, devendo-se pesquisar o sistema atual brasileiro, os modelos alternativos disponíveis e consultar profissionais de diversos setores correlacionados ao desempenho da produção agropecuária.

\subsection{Introdução}

No final da década de 80 , com o aprofundamento da crise interna brasileira, os recursos do Tesouro Nacional destinados ao Sistema Nacional de Crédito Rural, ao Programa de Garantia da Atividade Agropecuária (Proagro, subseção 4.2.2) e à Política de Garantia de Preços Mínimos sofreram fortes reduções. O país vinha de duas décadas de recursos fartos e subsidiados, cuja política de desenvolvimento estava voltada ao suporte da nascente indústria fornecedora de insumos e de processamento de produtos, à formação de capital rural e ao aumento de produção. 
Com o corte dos subsídios e as elevadas taxas de inflação e juros, os financiamentos agropecuários tornaram-se dificilmente administráveis. Na mesma época, o Proagro começou a sofrer déficits operacionais, devido a diminuição do fluxo de recursos provenientes do Tesouro Nacional. Por proteção, adotou taxas de prêmio baseadas nos resultados dos anos anteriores, como forma de elevação de receitas. Mas nada disso adiantou e o pagamento das indenizações foi avolumando-se a ponto de comprometer vários produtores, uma vez que, em pleno processo inflacionário, a correção de alguns compromissos do Proagro era menor que a das dívidas dos financiamentos rurais que os produtores não haviam conseguido honrar.

A fama de não-pagador, atribuído ao Proagro, e as altas taxas de prêmio fizeram com que produtores que possuíam menores riscos abandonassem o programa e preferissem produzir sem seguro.

As companhias de seguros também atravessaram um processo parecido, embora possuíssem responsabilidades de apenas $20 \%$ sobre os seguros que operavam até 1993. O restante era suportado pelo Instituto de Resseguros do Brasil (IRB, subseção 4.2.3) e pelo Fundo de Estabilidade do Seguro Rural (FESR, seção 4.1). A partir do final de 1995, as responsabilidades inverteram-se e o IRB passou a responder por apenas $20 \%$ e as seguradoras, por $80 \%$.

Esses fatores ligados ao Proagro e às companhias seguradoras contribuíram para diminuir o volume de contratos de seguros rurais, por falta de interesse tanto dos produtores, quanto das companhias de seguros.

Desde então, o Proagro vem passando por uma profunda reestruturação administrativa e técnica, reduzindo a gama de riscos cobertos e, como conseqüência, diminuindo as taxas de prêmios. Adotou também o zoneamento agrícola regionalizado, inicialmente para as principais culturas de verão e inverno. $O$ fato mais importante dessa reestruturação foi a liberação de recursos do Tesouro Nacional para o pagamento de débitos atrasados. 
Com relação às companhias de seguros, após a mudança de responsabilidades com o IRB em 1995, apenas a Companhia de Seguros do Estado de São Paulo (Cosesp, subseção 4.2.1) continuou a operar com seguros rurais. Passou por uma rigorosa reestruturação administrativa e está apresentando resultados satisfatórios. Sua mais importante novidade é a expansão de seus trabalhos para o Estado do Paraná, já autorizada pelo IRB.

Em 1996, com a queda do monopólio do IRB, o mercado ressegurador passou a admitir outros concorrentes, abrindo a possibilidade da entrada de companhias internacionais. A tendência é de, a médio prazo, seguradoras e resseguradoras terem interesse em participar do mercado de seguros rurais brasileiro.

A idéia de realizar este trabalho partiu da observação de diversos produtores da Região Centro-Oeste do Brasil, principalmente arrendatários, entre os anos de 1989 e 1992, que, ao buscarem novas fronteiras para expansão de seus empreendimentos, arriscavam o patrimônio de que dispunham e para diminuírem o risco de ocorrências relacionadas à natureza, utilizavam a cobertura do Proagro. Entretanto, as indenizações não eram pagas a todos os produtores, porque o Tesouro Nacional não dispunha de recursos suficientes para cumprir seus compromissos. Isso tornou alguns produtores inadimplentes nos bancos, impossibilitando a obtenção de recursos para um novo ciclo produtivo.

Adicionalmente, as diversas experiências econômicas adotadas pelo governo, a partir de 1990, com políticas de congelamento de preços acompanhadas de explosões de consumo e de preços, colaboraram para elevar o nível de endividamento dos produtores (hoje securitizados ${ }^{1}$ ). Deste modo, muitos deles, além de terem

\footnotetext{
${ }^{1} A$ securitização foi o meio encontrado pelo governo para solucionar os mais de $R \$ 7$ bilhões em dividas de produtores rurais, até o limite de $\mathrm{R} \$ 200.000,00$ por produtor, acumuladas desde 1989. O governo emitiu Títulos do Tesouro Nacional em favor dos bancos, em troca do recebimento futuro das prestações da dívida (a primeira venceu em novembro de 1997 e a última vencerá entre 2002 e 2003), com possibilidade de entrega de produto ao invés do dinheiro (equivalência), de acordo com o preço de mercado. Segundo informações dos sindicatos rurais patronais, as dívidas que ultrapassam $R \$ 200.000,00$ por produtor podem somar outros $\mathrm{R} \$ 4$ bilhões.
} 
comprometido todos os seus bens, também viram escapar o sonho de tornarem-se futuros proprietários de terras.

Atualmente, observa-se o desenvolvimento de modernos instrumentos de financiamento e mecanismos de administração de riscos de preços, como Cédula de Produto Rural (CPR) e mercados futuros e de opções agropecuários, enquanto instrumentos para administração de riscos relacionados às ocorrências da natureza, ainda possuem estruturas frágeis e precisam ser desenvolvidos.

Nos EUA, o processo de redução de intervenção governamental nos seguros rurais intensificou-se em 1994, através do Federal Crop Insurance Reform Act of 1994. Este Decreto deu início a uma série de estudos que resultaram na criação de modelos pilotos de seguros rurais com cobertura de receita esperada, utilizando-se os mercados futuros. Estes modelos vêm crescendo ano após ano e indicam uma tendência para estabilização da renda rural.

Espera-se, através do levantamento de informações atualizadas do seguro no Brasil e nos EUA, dos modelos alternativos e de discussões e análise dos depoimentos direcionados, obter propostas que poderão contribuir para o desenvolvimento dos seguros rurais no Brasil.

\subsection{Objetivos}

O objetivo geral deste trabalho é analisar as recentes propostas e colher sugestões do agribusiness para o desenvolvimento de produtos e ações que visem elevar a atratividade dos seguros rurais brasileiros e conseqüente utilização de seguros rurais pelos setores de produção agropecuários.

Os objetivos específicos são investigar junto aos integrantes do agribusiness brasileiro: (a) se os modelos alternativos pesquisados podem contribuir para o 
desenvolvimento do seguro rural; (b) quais as sugestões para implementação do seguro rural.

Para ser alcançado tal objetivo, deverão ser desenvolvidos as seguintes etapas:

- Caracterização da atividade seguradora agropecuária, para a formação de conceitos fundamentais à compreensão e à análise dos seguros rurais;

- Detalhamento da evolução recente do Proagro, Cosesp e IRB, situando o esgotamento e os reflexos atuais no setor produtivo;

- Abordagem das ações mais recentes no campo político, que auxiliarão o entendimento das posições adotadas pelos diversos setores atualmente;

- Caracterização do seguro rural norte-americano, que situarão a profundidade das mudanças estruturais e conceituais;

- Realização de pesquisas para levantamento de modelos alternativos, criados a partir da iniciativa privada, que estão sendo operados ou em fase de estruturação;

- Elaboração de questionários que colherão as opiniões de diversos profissionais de setores ligados à produção rural, como produção, comercialização, processamento, agentes financeiros e agentes de seguros. Esses questionários procurarão levantar aspectos operacionais relacionados a cobertura e prêmios, tipos de sinistros, papel do Estado, interesse do setor privado e instrumentos alternativos. 
2 RISCOS 


\section{RIScos}

O desempenho apresentado pelos setores da economia, muitas vezes, está relacionado aos diferentes graus de riscos específicos de cada atividade. $O$ risco de qualquer ação ou empreendimento é a possibilidade de ocorrência de algum resultado inesperado.

Riscos incertos são aqueles que apresentam impossibilidade de previsão dos resultados, ou seja, cujas conseqüências de determinada ação não podem ser antecipadamente conhecidas. Os possíveis resultados baseiam-se tradicionalmente no cálculo da probabilidade de ocorrência, formulada a partir da análise das repetições de dados. Quanto mais complexa é a realização desses estudos e análises, mais incerta é a ação ou o empreendimento (SELDON \& PENNANCE, 1968).

Os riscos que apresentam possibilidade de previsão, através de estudos matemáticos, podem ser eliminados ou minimizados, sendo divididos e transferidos para agentes especializados em sua administração. Os riscos incertos, que não podem ser transferidos, deverão ser suportados pelos empresários, à medida que suas expectativas de lucro suplantem a possibilidade de perda. Os riscos inseguráveis têm forte ligação com a magnitude do lucro.

Segundo SANDRONI (1989, p. 148), "incerteza é a situação em que, partindo-se de determinado conjunto de ações, chega-se a vários resultados possíveis. Os resultados são conhecidos, mas não a probabilidade de eles ocorrerem. Caso as probabilidades sejam conhecidas, fala-se em risco".

Empreendimentos comerciais e industriais são suscetiveis a todos os tipos de incertezas sociais e econômicas; entretanto, adicionalmente, a agropecuária, além de 
ser suscetível às mesmas incertezas, ainda precisa suportar riscos relacionados a eventos naturais, pelo seu contínuo contato com as forças da natureza. Estas evidências, por si só, elevam a agropecuária à condição de atividade de alto risco, requerendo distinção dos demais setores. 


\subsection{Riscos Agropecuários}

Segundo RAY (1981), os riscos agropecuários podem ser classificados como mostrado na Figura 1.

Riscos da Propriedade e do Empreendimento Rural

Riscos Pessoais

Fonte: RAY (1980)

$$
[
$$

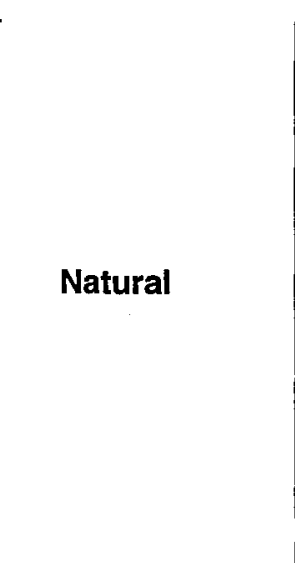

prase

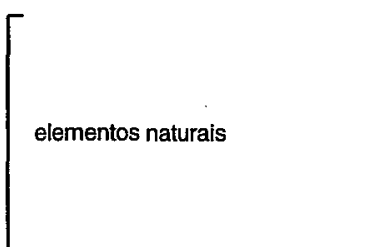
incêndio e raio granizo enchente vendaval excesso de umidade seca geada e nevasca etc.

doenças de plantas e animais $\left[\begin{array}{l}\text { parasitas } \\ \text { fungos } \\ \text { tuberculose } \\ \text { etc. }\end{array}\right.$

pragas e insetos

$\left[\begin{array}{l}\text { besouros } \\ \text { lagartas } \\ \text { ratos } \\ \text { etc. }\end{array}\right.$

delinqũência

$$
\left[\begin{array}{l}
\text { incêndio } \\
\text { roubo } \\
\text { fraude }
\end{array}\right.
$$

golpe

distúrbios civis

guerra

mudanças no ambiente social

mudanças tecnológicas

administração da qualidade

delinqüência moral

$\left[\begin{array}{l}\text { do fazendeiro } \\ \text { do empregado }\end{array}\right.$

flutuação do preço

Econômico $\quad\left[\begin{array}{l}\text { flutuação do preço } \\ \text { inesperadas quebra ou depreciação de investimentos } \\ \text { elevação nos preços dos insumos }\end{array}\right.$

Econômico $\quad\left[\begin{array}{l}\text { flutuação do preço } \\ \text { inesperadas quebra ou depreciação } \\ \text { elevação nos preços dos insumos }\end{array}\right.$

.

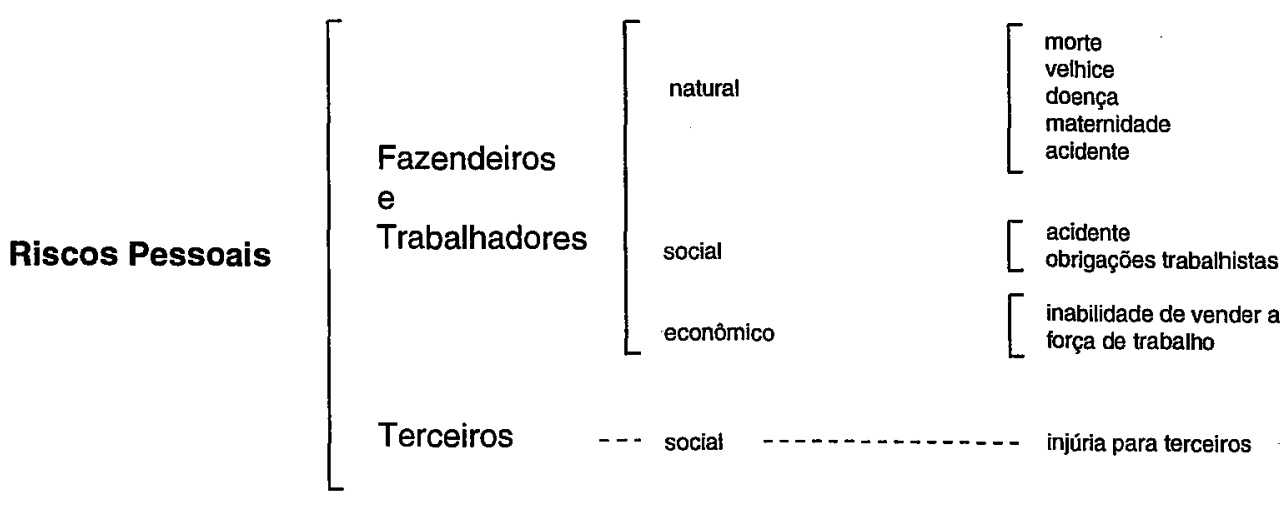




\subsubsection{Riscos da Propriedade Agropecuária}

\section{$\underline{\text { Riscos Naturais }}$}

(a) Elementos naturais: são riscos relacionados à meteorologia, ou seja, deficiência de umidade (seca), excesso de umidade (enchente), excesso de frio (geada, neve), granizo, tornado e terremoto, incêndio espontâneo etc.;

(b) Doenças de plantas e animais;

(c) Ataques de insetos e outras pestes.

A variabilidade da produtividade, devida às incertezas com relação aos riscos naturais, é característica essencial da atividade rural. No setor industrial, os resultados podem ser previstos e controlados, enquanto que, na agropecuária, as técnicas de previsão não possuem o mesmo grau de exatidão.

\section{Riscos Sociais}

Podem ser resumidos em: incêndio, roubo, fraude, colisão, guerra, mudanças estruturais sociais, mudanças tecnológicas, radiação nuclear etc.

\section{Riscos Econômicos}

(a) Probabilidade de flutuações nos preços dos produtos agropecuários, não antecipados pelos produtores, com origem na relativa inelasticidade-preço da demanda e da oferta.

A característica de inelasticidade-preço da demanda e oferta de produtos agrícolas, conduz a conclusões importantes no que se refere ao risco agropecuário. Os aumentos de demanda são mais constantes, uma vez que as variações dos três principais fatores de demanda (alimentação humana, animal e matéria-prima industrial) tendem a modificar-se lentamente, o que não gerará elevados níveis de variações de 
preços. No caso de diminuição de oferta, pela dificuldade em ajustar rapidamente a produção, podem surgir oscilações de preços, causando incertezas em períodos mais longos. Entretanto, o que se observa nos mercados agropecuários é a conjunção desses dois fatores em graduais específicos, gerando fortes oscilações.

(b) Probabilidade de perda ou de depreciação inesperada de investimentos, devida a causas naturais e sociais. Os investimentos na aquisição de fertilizantes e corretivos, bem como na manutenção de máquinas e implementos, devem ser realizados mesmo na possibilidade de quebra de safra.

(c) Probabilidade de elevação nos preços dos insumos, sem a correspondente elevação nos preços do produto.

\subsubsection{Riscos Pessoais}

Os riscos pessoais surgem da possibilidade de perda de receitas ou capital, sendo causados pela incerteza apresentada por fatores humanos. Podem ser resumidos como: morte, invalidez, velhice, acidentes, inabilidade profissional etc.

\subsection{Riscos Relacionados à Renda do Produtor Rural}

De todos os riscos apresentados na seção anterior, serão abordados de maneira mais aprofundada os riscos naturais e econômicos, uma vez que o sistema de seguros agropecuários no Brasil efetua cobertura apenas de riscos naturais. Com o desenvolvimento dos mercados futuros e de opções, existe a possibilidade de se oferecer cobertura aos riscos econômicos.

A seqüência de operações interdependentes que têm como objetivo produzir, modificar e distribuir um produto é definida como cadeia agroindustrial (DAVIS \& 
GOLBERG, $1957^{2}$ ), op. cit. in SOUSA (1996), ou agribusiness. Os setores que se utilizam de alguma maneira da atividade de produção agropecuária, fabricando e fornecendo insumos, processando e distribuindo mercadorias ou consumindo produtos acabados, dependem fundamentalmente da variação da renda do produtor rural.

Pode-se considerar que uma diminuição de renda no setor de produção agropecuária deverá influenciar negativamente os demais integrantes do agribusiness. Segundo MARTINS (1985, p. 2), "cabe salientar que o rebaixamento do risco agrícola seria benéfico para toda a economia, pois o risco gerado na agricultura propaga-se para outros setores, principalmente se não houver uma política deliberada de estoques reguladores e controle de preços, ficando então a população consumidora diretamente exposta aos acidentes produtivos da agricultura. Na eventualidade de quedas acidentais de produção (bem como de estruturais) os demais setores da economia têm reduzida a massa de salários destinada à aquisição de bens não-agrícolas, ou não encontram volume suficiente de matéria-prima para operar, ou sofrem redução no volume de vendas de insumos aos produtores."

A renda do produtor rural $(R)$ pode ser medida pela quantidade de mercadorias produzidas $(Q)$, multiplicada pelo preço de venda $(P)$, e subtraído esse resultado dos custos totais $(\mathrm{C})$ durante $\mathrm{o}$ ano. Nota-se que, nesta simples equação, as três variáveis estão associadas diretamente a riscos de maior e menor grau de imprevisibilidade, sobre a qual o produtor rural não possui influência direta. As variáveis de maior imprevisibilidade são preço de venda $(P)$ e quantidade produzida (Q).

Os preços dos fatores de produção, que determinam os custos totais (C), também possuem características imprevisíveis, porque estão igualmente sujeitos às forças de oferta e demanda de cada mercado específico; mas suas variações representam um risco proporcional à participação de cada fator no custo total.

\footnotetext{
${ }^{2}$ DAVIS, J.H.; GOLDBERG, R.A. A concept of agribusiness. Cambridge. Harvard University, 1957.
} 
Do ponto de vista do mercado, todas as forças agregadas de oferta e demanda refletem-se na variável preço. Mas a oferta de uma mercadoria também é influenciada pela quantidade de volume produzido, que, por sua vez, é estabelecido em grande parte por evolução climática, incidência de pragas e doenças etc., durante o desenvolvimento da cultura ou criação.

Não se deve esquecer que, mesmo em anos de estabilidade de oferta e demanda, também existem variações de preços relacionadas aos movimentos de safra e entressafra, chamadas sazonalidade de preços agropecuários.

Do ponto de vista do produtor rural, uma diminuição em sua expectativa de produção inicial e/ou uma diminuição nos preços de venda influenciarão negativamente sua renda. Isto é, as variações expressivas de renda do produtor rural estão relacionadas a apenas dois tipos de movimentos: oscilações de preços e oscilações no volume de produção.

\subsubsection{Incertezas Relacionadas a Oscilações de Preços}

As incertezas relacionadas a variações de preços podem ser minimizadas através de alguns programas ou estratégias públicas e privadas, a seguir relacionadas: 
(a) No Brasil, podem-se citar alguns instrumentos de política agrícola governamental, como o programa de Política de Garantia de Preços Mínimos $(P G P M)^{3}$, Aquisição do Governo Federal (AGF), Programa de Opções de Venda ${ }^{4}$, Preço de Liberação de Estoques (PLE) ${ }^{5}$, Prêmio de Escoamento da Produção (PEP) etc. Esses programas procuram diminuir a sazonalidade ou as oscilações indesejáveis de alguns produtos agropecuários, tendo como principal objetivo a manutenção da renda do produtor rural, incentivando assim sua permanência na atividade. Evidentemente, essa diminuição da curva de sazonalidade de determinado produto, favorece os demais integrantes da cadeia.

Nota-se na Figura 2 o fluxo esquemático do resultado que essas políticas pretendem alcançar. Inicialmente, pode-se observar a sazonalidade de preços de um produto de ciclo anual de verão, por exemplo o milho, quando o plantio é realizado entre os meses de setembro e outubro e a colheita, entre de março e maio. $\mathrm{Na}$ colheita, eleva-se significativamente a oferta desse produto no mercado, deprimindo seu preço; em contrapartida, na entressafra, no final do ano, a escassez determina uma forte elevação dos preços. A diminuição da amplitude dessa curva de sazonalidade é o objetivo do governo. Para tanto, na época da colheita, são aplicadas

\footnotetext{
${ }^{3}$ Política de Garantia de Preços Mínimos (PGPM): É um dos instrumentos de política agrícola que tem o objetivo de estabilizar a renda do produtor rural através de um preço mínimo estabelecido pelo governo. Este instrumento sempre esteve associado ao Empréstimo do Governo Federal Com Opção de Venda (EGF-COV), que nada mais é do que um financiamento de carregamento de estoque até a entressafra, quando os preços poderiam estar mais altos. Mas, caso os preços ainda estivessem abaixo do preço mínimo, a Companhia Nacional de Abastecimento (Conab) adquiriria o produto através da Aquisição do Governo Federal (AGF) e pagaria o produtor ou saldaria o empréstimo bancário.

${ }^{4}$ O Programa de Opções de Venda foi utilizado pela primeira vez na colheita da safra de milho de 1997 (fevereiro a junho). Seu objetivo era sinalizar um preço remunerador na entressafra, para que o produtor se sentisse incentivado a não vender todo o milho por ocasião da colheita. Entretanto, se o preço na entressafra estivesse melhor que o contratado, o produtor poderia não exercer a opção e vender o milho no mercado. Este moderno instrumento deverá substituir a PGPM nos próximos anos. O funcionamento dos mercados de opções será detalhado na seção 6.3.

${ }^{5}$ O Preço de Liberação de Estoques (PLE) é o nível máximo de preços que o mercado de alguns produtos (que fazem parte dos estoques do governo) pode atingir antes que o governo inicie as vendas de seus estoques. Ou seja, o governo só pode intervir no mercado de alguns produtos, vendendo estoques reguladores, após os preços de mercado ultrapassarem o PLE.

${ }^{6}$ Prêmio de Escoamento de Produção (PEP): Criado em 1997 e operacionalizado com trigo, milho e algodão (maio/98), tem o objetivo de escoar as mercadorias produzidas nas fronteiras agrícolas. É uma subvenção governamental dada aos consumidores que compram produtos através de leilōes efetuados pela Conab, baseados nos preços de paridade de importação.
} 
as políticas descritas acima para a diminuição do excesso de oferta no mercado, enquanto que, na entressafra; procede-se a elevação da oferta através da venda de estoques.
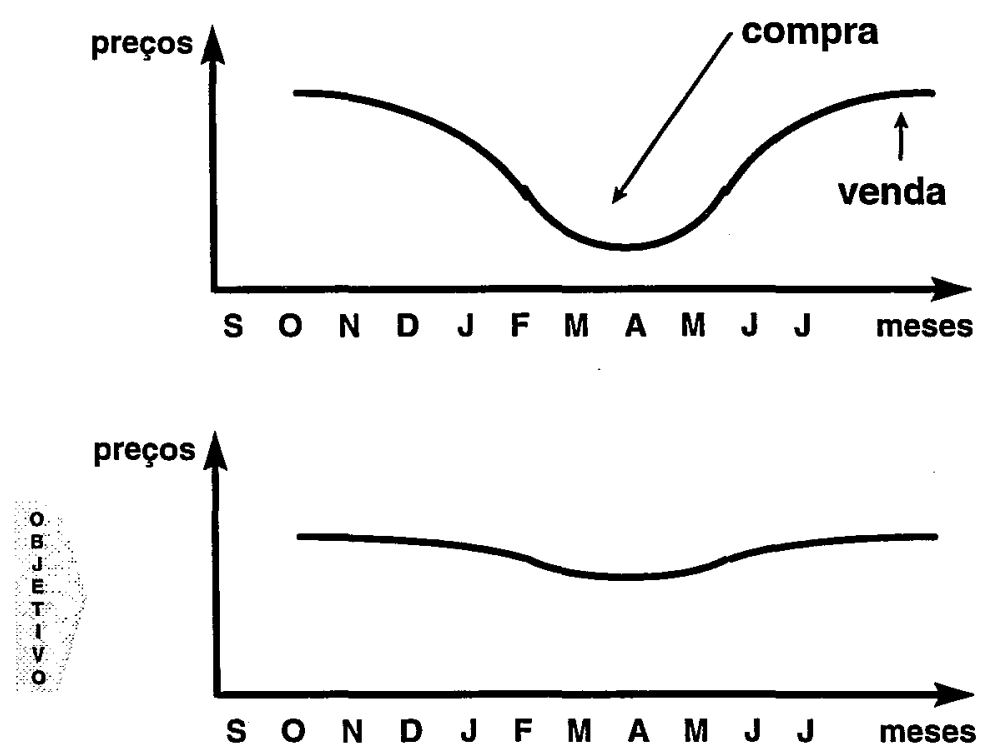

Fonte: CAFFAGNI (1997)

Figura 2. Política de Estabilização de Preços do Governo Brasileiro

(b) Nos EUA, pode-se citar o programa Deficiency Payments: Os produtores que participavam do programa federal anual de commodity para trigo, grãos alimentícios, arroz ou algodão tinham o direito de receber a diferença entre o preço objetivo, estabelecido pelo governo, e o preço de mercado. Com a aprovação da nova lei agrícola norte-americana, Federal Agriculture Improvement and Reform Act of 1996, o programa deficiency payments deverá cair gradualmente até o ano 2002 (YOUNG \& WESTCOTT, 1996).

(c) Utilização do mercado a termo: É uma negociação privada, na qual o produtor negocia antecipadamente um determinado preço para sua mercadoria com um comprador ou investidor, prevendo ou não adiantamento do valor negociado, através de negociação direta ou em mercados organizados (bolsas de mercadorias). Como exemplo podem-se apontar a soja verde e a troca de insumo por produto, através dos contratos da Associação Nacional dos Exportadores de Cereais (ANEC), a Cédula de Produto Rural (CPR), contratos particulares etc. (a negociação de soja 
verde, troca insumo por produto e Cédula de Produto Rural serão detalhadamente descritas na seção 6.2, referente ao Seguro Garantia).

(d) Utilização de mercados futuros, em que vendedores e compradores que procuram proteção contra oscilações desfavoráveis de preços (produtores, cooperativas, agroindústrias etc.) e especuladores ou investidores que assumem riscos em troca de possíveis lucros com tais oscilações, negociam expectativas para os preços futuros. Esses preços são baseados em análises fundamentalistas (fatores que influenciam oferta e demanda futuras), gráficas, modelos matemáticos etc. Nesse mercado, o produtor poderá diminuir o risco de oscilação de preços, contrário aos seus interesses, vendendo parte da produção antecipadamente no preço futuro negociado, no tempo presente, garantido pelo mecanismo de ajustes diários positivos e negativos que refletirão a desvalorização e a valorização do produto físico, respectivamente (seção 6.3).

\subsubsection{Incertezas Relacionadas a Oscilações no Volume de Produção}

As incertezas relacionadas a possibilidade de diminuição no volume da produção esperada, devidas às ocorrências naturais imprevisíveis, podem ser minimizadas através do seguro rural ou programas governamentais de subsídio.

Nos últimos anos, tem-se observado no Brasil uma diminuição no volume de seguros rurais, de culturas seguradas e de riscos cobertos, devido a fatores de ordem política e econômica, como será visto nas subseções 4.2.1, 4.2.2 e 4.2.3. Algumas seguradoras que trabalhavam com o setor agropecuário até há poucos anos, não suportaram as dificuldades e acabaram por interromper sua operações. Atualmente, existem poucas companhias operando nesse segmento, sendo a mais importante a Companhia de Seguros do Estado de São Paulo (Cosesp).

O governo federal, como parte de sua política agrícola, também tem utilizado o Programa de Garantia da Atividade Agropecuária (Proagro) como outra modalidade 
de seguro rural. Mas, devido a fatores ligados às dificuldades que o governo atravessa, esse programa tem sofrido violentas crises. Atualmente, reformulações vêm sendo implementadas por sua atual administração, podendo-se esperar uma evolução positiva no médio prazo.

O esgotamento das tradicionais políticas de subsídios do governo federal, cujos objetivos pretendiam estabilizar a renda do produtor rural (minimizando o risco de preços e de produção), tem possibilitado o desenvolvimento de instrumentos privados de diminuição de riscos de preços.

Contudo, alguns desses instrumentos privados, mercados a termo e futuros, precisam estar amparados por seguros rurais. Segundo AZEVEDO-FILHO et al. (1996, p. 3), "uma seca forte que atinja a região produtora causando uma diminuição na produção poderá resultar em preços mais elevados, contribuindo para um equilíbrio da receita dos produtores na região. Nesta situação é possível que a fixação do preço futuro venha até mesmo a aumentar o risco associado à receita futura". Ou seja, quando um produtor rural assume uma posição de proteção contra queda de preços, deve vender contratos nos mercados futuros. Esta operação pressupõe que haja ou haverá um estoque físico da mercadoria negociada, uma vez que a regra básica de funcionamento dos mercados futuros é que se os preços no mercado futuro subirem, o produtor (que está vendido) deverá pagar a diferença (ajuste diário) para a contraparte; entretanto seu estoque físico ganhará vaior, neutralizando o desembolso realizado. $\mathrm{Na}$ época de liqüidação do contrato, o preço da mercadoria física, subtraído dos ajustes diários pagos, resultará no preço objetivo estabelecido anteriormente pelo produtor. Mas, caso uma seca generalizada atinja o produtor posicionado no mercado futuro, a perda será maior, visto que, além de não possuir estoques, ele deverá pagar os ajustes diários, pois a escassez de oferta deverá elevar os preços (seção 6.3). 


\subsection{Administração de Riscos}

Com a forte queda no número de segurados cobertos pela Cosesp e pelo Proagro, poder-se-ia esperar um crescente volume de produtores em dificuldades, com conseqüente diminuição no volume de produção. Entretanto, a produção de grãos do Brasil vem registrando crescimento ao longo dos últimos anos (as safras 95/96, 96/97 e 97/98 produziram quantidades de 73,6,78,6 e 78,8 milhões de toneladas, respectivamente). Pode-se questionar, com a diminuição de utilização de seguros rurais, se, intuitivamente, o produtor rural não esteja desenvolvendo técnicas alternativas de administração de riscos.

COELHO (1997) levantou que, nos EUA, a maioria dos produtores utilizavam programas do governo como forma de reduzir o risco de produção, seguidos pela diversificação de atividades dentro e fora da fazenda, conforme a Tabela 1 . Os seguros rurais aparecem apenas em quarto lugar.

Tabela 1. Estratégias adotadas para administração de riscos, EUA (1993)

\begin{tabular}{cccc}
\hline ESTRATÉGIAS & $\begin{array}{c}\text { Partiç̣pação dos produtores por intervalo de renda (\%) } \\
\text { US\$ 50 a 250 mil } \\
\text { US\$ 250 a 500 mil }\end{array}$ & $\begin{array}{c}\text { Acima de } \\
\text { US\$ 500 mil }\end{array}$ \\
\hline Programas Governamentais & 57 & 0 & 47 \\
Diversificação & 30 & 48 & 48 \\
Arrendamento & 23 & 36 & 39 \\
Seguros Rurais & 35 & 24 & 18 \\
Parcerias & 19 & 11 & 9 \\
Contratos Insumos & 9 & 5 & 16 \\
Aluguel de Equipamentos & 3 & 2 & 10 \\
Outros & 15 & 10 & 16 \\
\hline
\end{tabular}

Fonte: ERS/USDA op. cit. in COELHO (1997)

AZEVEDO-FILHO (1997) considera que, além de seguros rurais, podem existir várias maneiras de administração de riscos, como diversificação das atividades dentro e fora do setor de produção, acumulação de reservas de valor em animais ou outros bens, transferências entre membros familiares, facilidades creditícias formais e informais, etc. O autor lembra, também, que nos EUA apenas um quarto dos prêmios

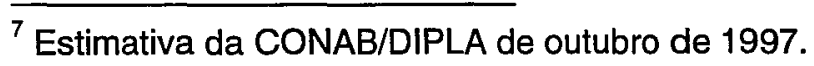


recolhidos está associado a seguros contra diminuição da produtividade. $O$ restante relaciona-se a indenizações de funcionários, roubos, acidentes com máquinas e intoxicações com defensivos agrícolas.

MARTINS (1985) concluiu que a diversificação de produção de diferentes culturas na mesma propriedade gera uma eficiente diminuição do risco de produção, proporcionando redução no custo do seguro (prêmio). A diversificação diminui o risco sem reduzir a margem de lucro. Indiretamente, haveria benefícios relacionados a diminuição de custos pela criação de economias internas, rotação de cultura com melhorando da fertilidade do solo, aumento do giro do capital, redução da sazonalidade do trabalho e outros fatores de produção. Embora a proposta testada pela autora seja importante, não há informações de aplicação ou incentivo do modelo de diversificação por parte de qualquer companhia de seguros agrícolas no Brasil.

No país pouco se tem estudado a respeito dos métodos alternativos de administração de riscos. Não se encontram pesquisas sobre o nível de diversificação das propriedades rurais, o que contribuiria para levantar a necessidade de determinadas políticas para o setor de produção.

Pode-se observar, empiricamente, que regiões de fronteira agrícola (Região Centro-Oeste) possuem alto nível de ocupação por filhos de produtores dos estados do sul. Talvez essa expansão, para abertura de novas áreas, consista em um movimento intuitivo de diminuição de riscos.

Com a diminuição do subsídio nas políticas governamentais norte-americana (YOUNG \& WESTCOTT, 1996) e a adoção de programas de seguros agrícolas que estabelecem cobertura de renda (capítulo 5), os seguros rurais nos EUA deverão assumir parte do papel das políticas governamentais de subsídios, gerando elevação de demanda para os próximos anos, segundo COELHO (1997) e AZEVEDO (1997).

Para o Brasil, espera-se também que, com o desenvolvimento de programas de seguros alternativos com cobertura de renda esperada, aliado a diminuição das 
subvenções governamentais, resulte na elevação da atratividade do seguro rural aumentando sua importância na administração de riscos agropecuários. 
3 A ATIVIDADE SEGURADORA E SUAS ORGANIZAÇÕES 


\section{A ATIVIDADE SEGURADORA E SUAS ORGANIZAÇÕES}

Este capítulo conceituará a atividade seguradora do ponto de vista das organizações envolvidas nesse mercado e não do ponto de vista do usuário do sistema, o produtor rural.

O seguro nasceu da necessidade de pessoas e empresas suportarem perdas individuais, através da associação entre elas. A função de um seguro de qualquer natureza é garantir a indenização do bem ao valor contratado, devido à ocorrência de algum evento danoso imprevisível ao objeto do seguro. $O$ objeto do seguro pode ser referente à vida, bens, responsabilidades e outros. Para se ter direito a esse benefício, deve-se efetuar o pagamento de uma taxa chamada prêmio a uma companhia de seguros, que representa um percentual do valor do objeto do seguro.

O funcionamento dos seguros está baseado no estudo estatístico da ocorrência de eventos aleatórios causadores de perdas, chamado estudo atuarial. 0 princípio do seguro consiste na acumulação de recursos em períodos de prosperidade, pelo agregado dos usuários, para cobrir eventuais perdas decorrentes de eventos incertos (mutualidade). "O seguro rural reduz o grau de incerteza ao agrupar os riscos de perdas imprevisíveis de muitos agricultores. Ainda que os riscos individuais continuem sendo incertos e imprevisíveis, com o seguro se reduz a incerteza total: os riscos podem ser previstos perfeitamente, quando se considera o conjunto" (HOFFMANN et al., 1978, pag 319).

"A essência do seguro repousa na eliminação do risco de perda individual, através da combinação de um grande número similar de indivíduos expostos, onde cada um contribui para um fundo comum, por intermédio de pagamento de prêmios 
suficientes para ressarcir a perda causada a qualquer indivíduo" (MALES, $1931^{8}$ ), op. cit. in RAY (1981).

É importante apontar que a atividade seguradora procura distribuir os riscos contratados no espaço e no tempo, isto é, assumindo o risco entre diversos empreendimentos fisicamente dispersos e com vários vencimentos.

Os sinistros (perdas) podem ser parciais ou totais, independentes ou correlacionados e em pequena escala ou generalizados/catastróficos. Para a proteção da indústria de seguros, foram criados mecanismos de salvaguarda como co-seguros, resseguros, retrocessões e fundos de estabilidade.

Co-seguros são operações em que seguradoras pulverizam o risco assumido entre diversas seguradoras, proporcionalmente às cotas estabelecidas entre elas. 0 resseguro é um contrato em que o segurador (cedente) transfere parte ou a totalidade de seu risco ao ressegurador (cessionário), através da cessão de parte do prêmio arrecadado, assumindo assim a posição de segurado perante o ressegurador. A retrocessão é transferência de parte do risco assumido pelo ressegurador a uma seguradora (retrocessionária).

Toda seguradora ou resseguradora possui fundos de estabilidade próprios, que funcionam como lastro em anos atípicos. Elas podem também reunir-se para formar um fundo comum. Segundo GÖPFERT et al. (1993), resumidamente, a "porcentagem de perda" de uma safra de uma região é mensurada por dois parâmetros, "a porcentagem das lavouras sinistradas" e a "fração de perda". Como o prêmio equivale apenas ao "potencial de perda" e à "taxa de juros", existem anos em que as seguradoras apresentam déficit e anos em que apresentam superávit de acordo com a ocorrência ou não de sinistros. Para equilibrar essas oscilações, faz-se necessário que a seguradora constitua seu fundo próprio, que pode ser operacionalizado por um contrato de empréstimo e aplicação entre o administrador da seguradora e seu agente financeiro.

${ }^{8}$ Encyclopaedia of the Social Sciences. Macmillan, Vol. VI, 8, p.95, 1931. 
Portanto, o valor do prêmio calculado para cada tipo de seguro deverá ser dividido proporcionalmente entre todos os agentes que assumem riscos, como seguradoras, co-seguradoras, resseguradoras etc., e alimentar um fundo de estabilidade.

O mercado segurador possui quatro níveis institucionais, corretores de seguros $^{9}$, companhias de seguros (comerciais, mútuas, cooperativas e governamentais, seção 3.1) que contratam diretamente com o cliente, resseguradoras (seção 3.1) que assumem parte do risco das seguradoras, e instituições que estabelecem normas, fiscalizam e regulam o mercado.

Atualmente, o Sistema Nacional de Seguros Privados é representado pelo Conselho Nacional de Seguros Privados (CNSP, seção 4.1), pela Superintendência dos Seguros Privados (SUSEP, seção 4.1), Instituto de Resseguros do Brasil (IRB, subseção 4.2.3), por seguradoras autorizadas a operar em seguros privados e corretores habilitados.

A seguir, discute-se, de maneira simplificada, o fluxo operacional da contratação de um seguro. Suponha-se que um indivíduo, ao tomar a decisão de segurar determinado bem, entre em contato com um corretor de uma companhia de seguros e requisite a contratação. A companhia possui os valores dos prêmios previamente calculados, baseados em estudos atuariais que levam em consideração a teoria estatística e os dados históricos de ocorrências de sinistros. Assinam o contrato, também chamado de apólice, a contratante, a companhia de seguros e o contratado, segurado ou beneficiário.

\footnotetext{
${ }^{9}$ Os corretores de seguros são o elo de ligação entre os segurados e as seguradoras. Prestam serviços ao segurado e constituem um segmento fundamental para a disseminação dos produtos. Deve-se salientar que, em todas as operações que envolvam pagamento de prêmios, necessariamente destaca-se uma porcentagem a título de comissão de corretagem, mesmo se a operação for executada entre uma companhia de seguros e uma resseguradora. Essa comissão é diferenciada para cada tipo de seguro e negociada livremente entre os agentes, podendo ser em torno de $15 \%$ do prêmio para seguros contra incêndio, $10 \%$ para avarias em cascos de navios petroleiros, até 30\% para automóveis e $5 \%$ para seguros do setor agrícola.
} 
Caso aconteça algum sinistro previsto nos termos da apólice como segurável, o beneficiário informa à companhia, que enviará um perito para levantar as perdas. Após realizar os cálculos, a seguradora pagará a indenização ao beneficiário. Em algumas modalidades de seguros, principalmente veículos, aplicam-se cláusulas contratuais de perdas dedutíveis, chamadas franquias, isto é, a indenização é paga descontando-se um valor ou uma porcentagem. Note-se que a franquia é aplicada para alguns tipos de seguros, com a finalidade de desmotivar o contratado a promover pequenos danos, por falta de zelo ou propositadamente.

O seguro agrícola possui algumas peculiaridades: o objeto do seguro é a produção que ainda não foi colhida, portanto, só existirá se for conduzida dentro de padrões técnicos agronômicos razoáveis aos olhos da seguradora; deve-se utilizar a assistência técnica de um engenheiro agrônomo para garantir a produtividade do empreendimento; difícil fiscalização, devida às características espaciais e geográficas da produção agropecuária.

Deve-se salientar que a atividade seguradora, principalmente no ramo rural, enfrenta dois importantes problemas, o que muitas vezes estabelece os resultados de determinadas seguradoras ou programas de políticas agrícolas. São eles o risco moral e a seleção adversa. O moral hazard ou risco moral refere-se ao segurado que, após comprar um seguro, altera seu comportamento com o objetivo de aumentar a probabilidade de receber o pagamento da indenização. A seleção adversa acontece quando os indivíduos possuem mais informações sobre a distribuição de seus próprios riscos do que as companhias de seguros, ou seja, o segurado tem conhecimento de que seu próprio risco é mais elevado que o estimado pela companhia seguradora. Indivíduos são levados mais facilmente a comprar um seguro se as expectativas de indenizações excedem as de pagamento dos prêmios.

Segundo COBLE et al. (1996), nos anos 90, nos EUA, elevou-se consideravelmente o volume de indenizações do principal seguro multi-risco daquele país, levantando suspeitas sobre o aumento de ocorrência de risco moral e seleção 
adversa. Considera-se também que a eficácia dos programas de seguros depende do entendimento dos efeitos desses fatores.

Esses problemas refletem-se na dificuldade em estudar $\circ$ passado para calcular a probabilidade de perdas futuras, devido à falta de dados históricos que reflitam o comportamento médio dos indivíduos que contratam seguro, ou seja, dados de ocorrências históricas não garantem que a probabilidade calculada esteja correta, porque os indivíduos com maior risco tendem a contratar mais seguros. :

Os problemas financeiros de companhias de seguros como Bemge, Banerj, Cosesp, União (RS), bem como do Proagro, podem estar relacionados com a elevação de ocorrência do risco moral e da seleção adversa, provavelmente devido ao esgotamento dos subsídios governamentais, à dificuldade de controle e à diminuição da responsabilidade do Instituto de Resseguros do Brasil sobre os riscos assumidos pelas companhias, no final de 1995 (subseção 4.2.3).

\subsection{As Organizações de Seguros Agropecuários ${ }^{10}$}

Este tópico procurará reunir sinteticamente as principais características que envolvem as organizações que atuam no setor de seguros agropecuários. Serão caracterizadas as seguradoras privadas, públicas e resseguradoras.

\footnotetext{
${ }^{10}$ Baseado em RAY (1981).
} 


\subsubsection{Seguro Privado}

O seguro privado é caracterizado por sociedades de seguro mútuo, cooperativas e companhias comerciais.

(a) As sociedades de seguro mútuo têm como objetivo essencial a divisão das responsabilidades entre seus membros (seção 6.1). Não é uma sociedade de capital aberto e não possui fins lucrativos, sendo constituída apenas por uma taxa de administração e pelo valor das perdas rateadas entre seus membros após a ocorrência do evento.

Os participantes de uma mútua são os próprios segurados, diferentemente de um seguro comercial, em que o segurado compra o seguro pelo valor do prêmio, transferindo a totalidade do risco contratado para a seguradora, exceto quando concorda em pagar uma franquia. A essência de uma sociedade de seguro mútuo é a troca de um risco pelo outro, isto é, de uma pequena probabilidade de grande perda por uma grande probabilidade de pequenas perdas.

Uma mútua atende a um princípio que a diferencia das demais organizações. É a ênfase dada ao elemento pessoal, ou seja, posição pessoal, caráter e opinião representam importantes contribuições relacionadas aos riscos assumidos e pagamentos de perdas rateadas.

(b) As sociedades cooperativas de seguro são organizações com caráter comercial e seguem preceitos e regras cooperativistas. São organizações sem fins lucrativos e os recursos excedentes ou sobras são distribuídos proporcionalmente entre os cooperados de acordo com o grau de utilização da cooperativa pelos seus membros. Possuem capital variável e livre entrada; a estrutura máxima e soberana de decisão é a assembléia geral, cujo princípio mais importante é o voto individual. 
No Brasil, tem-se notícia de poucas cooperativas que realizam seguro rural, entre elas a Cooperativa Agropecuária Batavo Ltda. e a Cooperativa Agrária Mista Entre Rios Ltda (seção 6.1).

As principais diferenças entre sociedade mútua e cooperativa são:

- A mútua apresenta menor número de membros do que a cooperativa;

- A cooperativa cobra taxas de capitalização, além das taxas de administração, enquanto a sociedade de seguro mútuo não as cobra;

- A cooperativa é uma empresa comercial de serviços e negócios.

(c) As companhias comerciais de seguro são organizações privadas constituídas por sociedades limitadas ou de capital aberto. Como têm o objetivo de gerar dividendos aos associados, a taxa de prêmio cobrada deverá ser suficiente para 'pagar indenizações, cobrir custos de administração das operações, constituir um fundo de reserva e gerar lucros.

As principais vantagens das sociedades de seguros mútuos e das cooperativas sobre as companhias comerciais estão relacionadas às operações que apresentam altas probabilidades de risco moral e seleção adversa. Por atuarem em áreas restritas, onde cada membro tem responsabilidade pelo resultado do grupo, criam-se espontaneamente controles e fiscalizações recíprocas.

Outra vantagem das mútuas e cooperativas é seu baixo custo de administração. Estima-se que uma grande companhia de seguros destina aproximadamente $40 \%$ de suas receitas em prêmios para pagamentos de comissões, taxas de representação, despesas veterinárias, salários técnicos, juros de capital, depreciações de instalações e lucro dos acionistas.

Como desvantagem, uma pequena sociedade cooperativa ou mútua não pode assumir altos riscos ou um grande número de pequenos riscos. Por isso, elas não conseguem cobrir os riscos de médios e grandes produtores. 
O princípio de pulverizar o risco no tempo e no espaço também não pode ser cumprido por uma sociedade mútua, enquanto que uma companhia de seguros com estrutura nacional tem essa facilidade.

No caso de eventos que em poucos minutos causam grandes destruições, como granizo e tempestades, as grandes companhias, públicas ou privadas, são capazes de absorver o impacto mais facilmente.

Finalmente, existem outros tipos de riscos que não podem ser suportados nem pelas companhias comerciais, nem pelas cooperativas e mútuas. Para tanto, há necessidade de estabelecer outro tipo de organização seguradora, o seguro público ou governamental.

\subsubsection{Seguro Público}

Em todo o mundo, existe uma grande quantidade de companhias de seguros públicos que atuam em áreas evitadas por companhias privadas, por serem consideradas de maior risco, podendo-se citar seguro contra granizo em regiões com alta incidência que não são atendidas por companhias privadas ou apresentam taxas de prêmios muito altas; cobertura de vida; incêndio; epidemias etc.

Como principal característica aponta-se a inexistência da necessidade de gerar excedentes para pagar dividendos a acionistas, diminuindo assim as taxas de prêmios cobradas. Sua atuação intervém na estrutura do mercado segurador em pelo menos dois aspectos: diminuição das taxas de prêmios cobradas por companhias comerciais e manutenção do segmento frente aos abusos do monopólio.

Alguns programas de seguro que, operados pelo governo ou outras agências públicas, realizam experimentos de riscos considerados incertos pelas companhias 
comerciais, operando sem lucro e com baixos custos para produtores, podendo ser caracterizado como monopólio virtual.

No que se refere à obrigatoriedade de participação, citam-se o seguro público voluntário e o compulsório. O seguro voluntário tem a necessidade de cobrar maiores taxas de prêmios, uma vez que, na média, quem procura seguro voluntariamente possui maiores riscos. Para o caso do seguro de vida, há necessidade de constituir um fundo de reserva para fazer frente ao posterior aumento do risco do segurado. $O$ seguro público compulsório pode ser dividido em três categorias:

- Obrigatório: O seguro privado é completamente excluído. É geralmente aplicado para cobrir o custo de produção e não a produtividade; entretanto, pode-se calcular o valor total da produção e optar por uma linha complementar na própria instituição;

- Cobertura mínima: Modalidade em que a competição privada somente é excluída de uma cobertura mínima, como em casos de seguro saúde, nos quais, acima de um mínimo, pode-se operar livremente em companhias privadas.

Opcional : O seguro é compulsório em apenas alguns casos, como no do Programa de Garantia da Atividade Agropecuária (Proagro), em que há obrigatoriedade apenas para 0 caso de o produtor utilizar linhas de créditos governamentais.

\subsubsection{Resseguro}

É um artifício para reduzir o risco assumido por uma seguradora no caso de ocorrência de eventos acima de determinado grau de sinistralidade ${ }^{11}$. A relação

\footnotetext{
${ }^{11}$ A sinistralidade mede o volume de pagamento de indenizações em relação aos prêmios recebidos, em determinado período. Será detalhadamente explicada na seção 3.2 e na subseção 4.2.1.
} 
contratual estabelece as circunstâncias de aplicação do resseguro, as obrigações no caso de pagamento de indenizações e as alocações dos prêmios recebidos.

O benefício mais importante estabelece-se dentro da principal filosofia da atividade seguradora, a distribuição de riscos sobre o tempo e espaço. Ou seja, uma resseguradora, por segurar as mais variadas atividades entre diversas companhias, diminui seu próprio risco, podendo socorrer seguradoras na ocorrência de eventos estatisticamente improváveis ou catastróficos, dando assim garantia e estabilidade ao sistema.

No caso de mútuas e cooperativas, que geralmente operam com um número pequeno de segurados, poucas atividades diferentes e em áreas restritas, a atuação de resseguradoras pode garantir a sobrevivência dessas organizações.

Os métodos para aplicação do resseguro podem ser:

(a) Resseguro Facultativo: é contratado por opção da seguradora, após a resseguradora analisar a natureza do risco, a probabilidade de perda e o caráter da companhia. A vantagem é a inexistência de acordos prévios, com condições fixadas para cada caso; em contrapartida, a seguradora não tem certeza se pode contar com um resseguro para a mesma razão, porque sempre necessita de analise prévia. É utilizada para riscos típicos agrícolas, animais de alto valor e benfeitorias;

(b) Tratado de Resseguro: é a união de duas ou mais agências que dividem o risco com o ressegurador, cada qual assumindo responsabilidades proporcionais à parte do prêmio recebido. Podem possuir o seguinte formato:

-.Plano de excesso de perda de riscos específicos: a resseguradora paga a diferença entre certa quantidade contratada e a perda total, isto é, perdas abaixo da quantidade contratada não são indenizadas pela resseguradora;

- Plano pro rata de seguros específicos: é comum em ocorrências como incêndio e raio. Os riscos são cedidos pelas seguradoras, principalmente mútuas, quando o ressegurador obriga-se a indenizar perdas na mesma proporção; 
Suponha que um produtor rural, membro de uma sociedade de seguros mútuos, deseje segurar uma benfeitoria que vale $\mathrm{R} \$ 40.000,00$, com $75 \%$ de cobertura ou $\mathrm{R} \$ 30.000,00$. A mútua concorda em suportar um seguro simples de até $\mathrm{R} \$$ $20.000,00$, mas, com a ação de um resseguro, pode segurar o valor total. No caso de uma perda total, nos dois tipos de seguro, a mútua pagará $R \$ 20.000,00$ e o resseguro, $R \$ 10.000,00$. Entretanto, em uma perda parcial de $R \$ 6.000,00$, o ressegurador não tem responsabilidade se tiver sido adotado o plano de excesso de perda, mas, no plano pro rata, sua responsabilidade será de 1/3, ou seja, $R \$ 2.000,00$. No plano pro rata cobra-se um prêmio maior.

- Plano de excesso agregado: a seguradora não é protegida por perdas individuais, mas pelos danos acumulados de um ano. $O$ objetivo é auxiliar a seguradora no fornecimento de cobertura em anos que apresentam altos índices de danos.

\subsection{Medidas Usuais de Desempenho da Atividade Seguradora}

Esta subseção procurará apresentar alguns parâmetros e medidas usuais de desempenho de organizações de seguros, cuja finalidade é auxiliar nas estratégias futuras, relacionadas a taxas de prêmios, indenizações e fundos de estabilidade.

Para que um evento seja segurável, sua ocorrência deve ser casual e permitir a utilização de métodos estatísticos para calculá-la. Para tanto, exige-se um confiável banco de dados, cuja utilidade seria estimar os fatores que causam perdas e sua taxa média de ocorrência; calcular a freqüência da distribuição de probabilidade; indicar o grau de incerteza através do desvio padrão ou do coeficiente de variação.

Os dados utilizados podem ser:

- brutos: relatos históricos de ocorrências de perdas e suas intensidades; 
- processados: são dados de experiências e resultados de companhias de seguros, como sinistralidade, relação custo/perda, etc., (essas notações serão definidas adiante).

De maneira ideal, o banco de dados deve apresentar dados históricos regionalizados de (a) eventos causadores de perdas, com informações de tipos de ocorrências, épocas do ano e intensidades de perda; (b) resultados de companhias de seguros.

Dados de resultados de companhias seguradoras refletem com maior fidelidade o comportamento histórico médio dos indivíduos que contratam seguro, estabelecendo maior precisão nas análises e nos cálculos das taxas a serem cobradas.

Estudando dados referentes a experiências de companhias seguradoras, pode-se analisar as perdas de duas maneiras:

(a) Sinistralidade (índice sinistros/prêmios):

A sinistralidade mede o volume de pagamento de indenizações em relação aos prêmios recebidos em determinado período. Se a quantidade de indenizações ficar acima do volume total de arrecadação de prêmios, a sinistralidade ultrapassará 1 , ou $100 \%$; caso contrário, a sinistralidade cairá abaixo dos $100 \%$, objetivo de qualquer companhia de seguros privada.

Pode-se observar um exemplo de medida de sinistralidade através da Figura 3 , que mostra os resultados associados à ocorrência de granizo, coletados em uma grande quantidade de companhias e sociedades mútuas de seguros francesas durante 46 anos. A sinistralidade média ficou em $71,1 \%$ e o desvio-padrão, em 23,03\%; o coeficiente de variação foi $32,38 \%$, valor relativamente baixo para seguros rurais. 


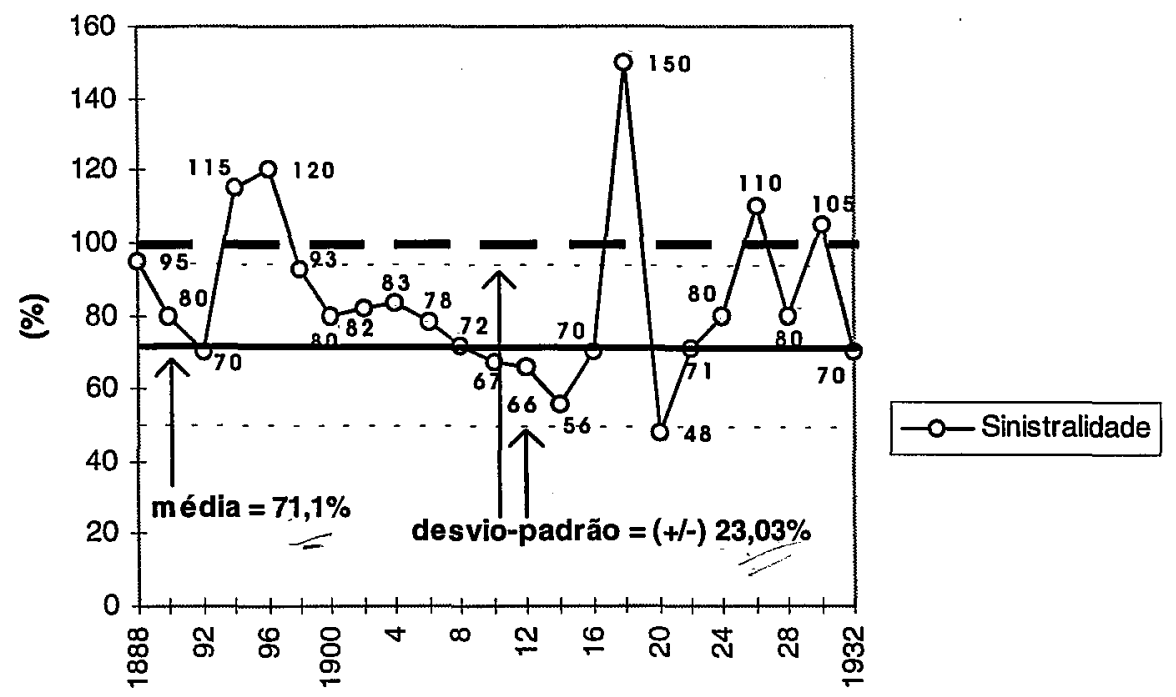

OBS.: Os valores representados estão aproximados.

fonte: (International Review of Agriculture, IIA, Rome, 1935, p.384) op. cit. in RAY (1980).

Figura 3. Análise das perdas decorrentes de granizo na França entre 1888 a 1932

Dos 46 anos analisados, 25 obtiveram sinistralidade de 41 a $70 \%$, sendo que a grande concentração de ficou entre 51 e $75 \%$. Na Figura 4, observa-se que a curva de distribuição de freqüência não é exatamente normal, possuindo uma cauda maior a direita.

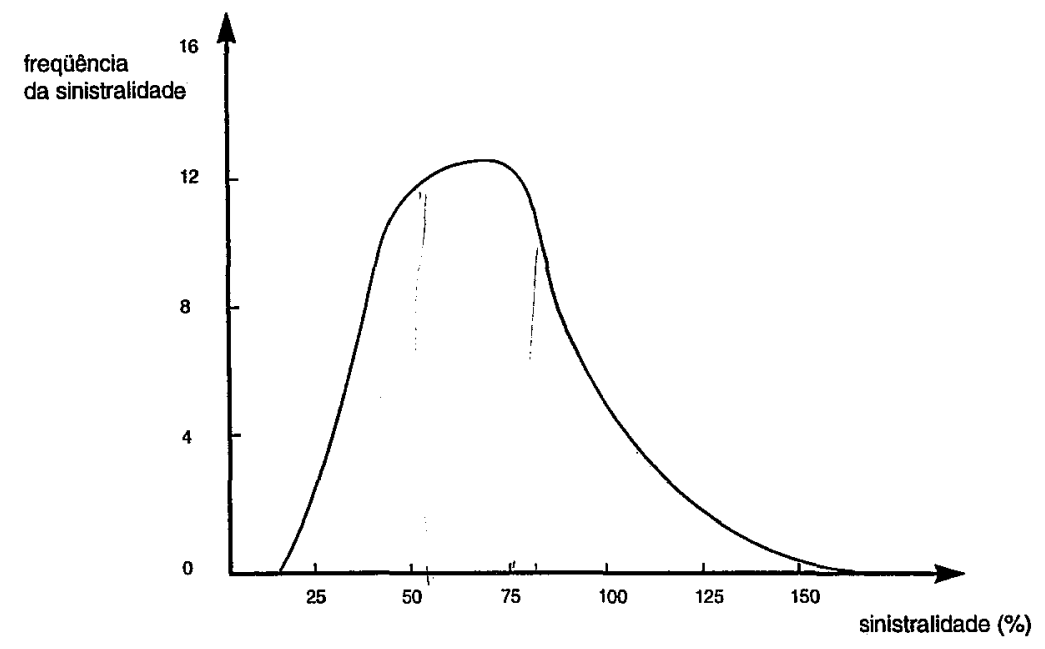

Fonte: (International Review of Agriculture, IIA, Rome, p. 384) op. cit. in RAY (1980)

Figura 4. Curva de distribuição de freqüência da sinistralidade 
Na subseção 4.1.1 será apresentada e discutida uma série histórica de sinistralidades da Cosesp, referente aos anos de 1979 a 1997.

(b) Índice indenizações/importância segurada (I/IS):

O segundo tipo de análise refere-se ao índice indenizações/importância segurada ( $1 / \mathrm{IS})$, que nada mais é que o volume de pagamentos referentes a perdas em relação ao volume total segurado. Nota-se que este índice, historicamente analisado, determina o custo relacionado às indenizações de uma companhia de seguros, ou seja, o prêmio líqüido. Se a essa porcentagem a companhia acrescer seus custos administrativos, reservas e projeção de lucros, estabelece-se o prêmio bruto que deverá ser cobrado do segurado.

A Figura 5 mostra a variação do índice indenização/importância segurada (I/IS) ou prêmio líqüido, em 66 anos, utilizando dados da companhia de seguros Bavarian State Hail Insurance, da Alemanha, referente à ocorrência de granizo. A média do índice é $1,79 \%$ e o desvio-padrão é $( \pm)$ 1,16, com coeficiente de variação igual a $64,81 \%$.

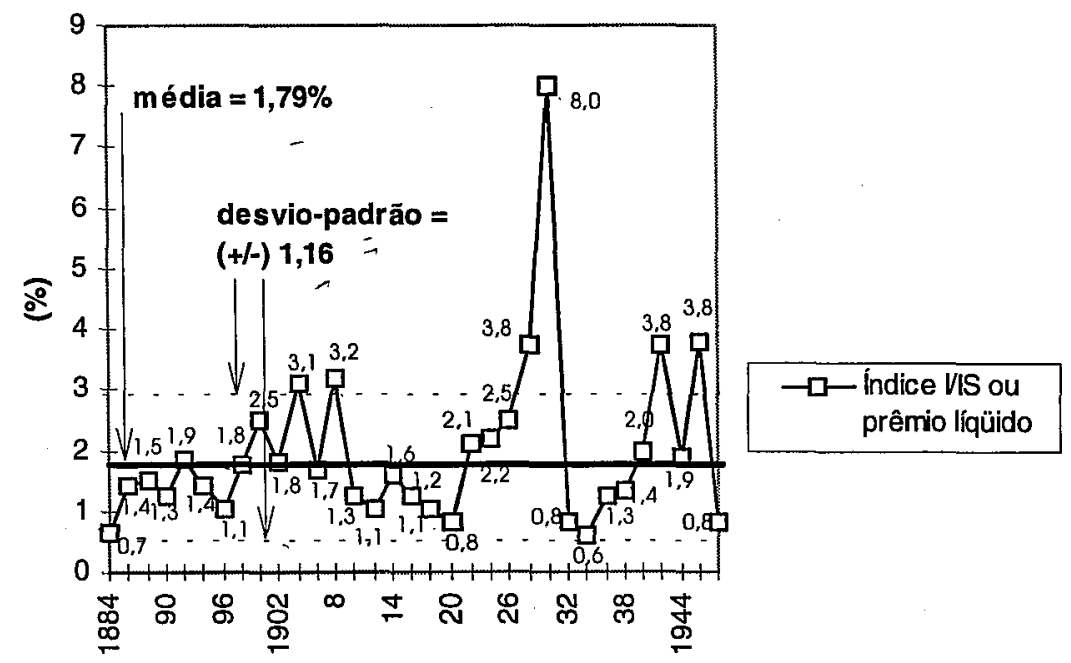

Obs.: Os valores representados estão aproximados fonte: (Dados obtidos na Bavarian State Hail Insurance Institute) op. cit. in RAY (1980)

Figura 5. Índice Indenização/Importância Segurada ou prêmio líqüido 
A curva de distribuição de freqüência possui uma cauda maior para a direita, indicando maior concentração de perdas entre os índices de 1 a $2 \%$.

Analisando dados relacionados à ocorrência de granizo em fumo, no município de Darlington, na Carolina do Sul (EUA), de 1924 a 1948, nota-se um I/IS de $4,19 \%$, com desvio-padrão de $3,8 \%$ e coeficiente de variação $97 \%$. A curva de distribuição de freqüência é exponencial negativa, mostrando que a probabilidade de grandes perdas é relativamente pequena (Figura 6).

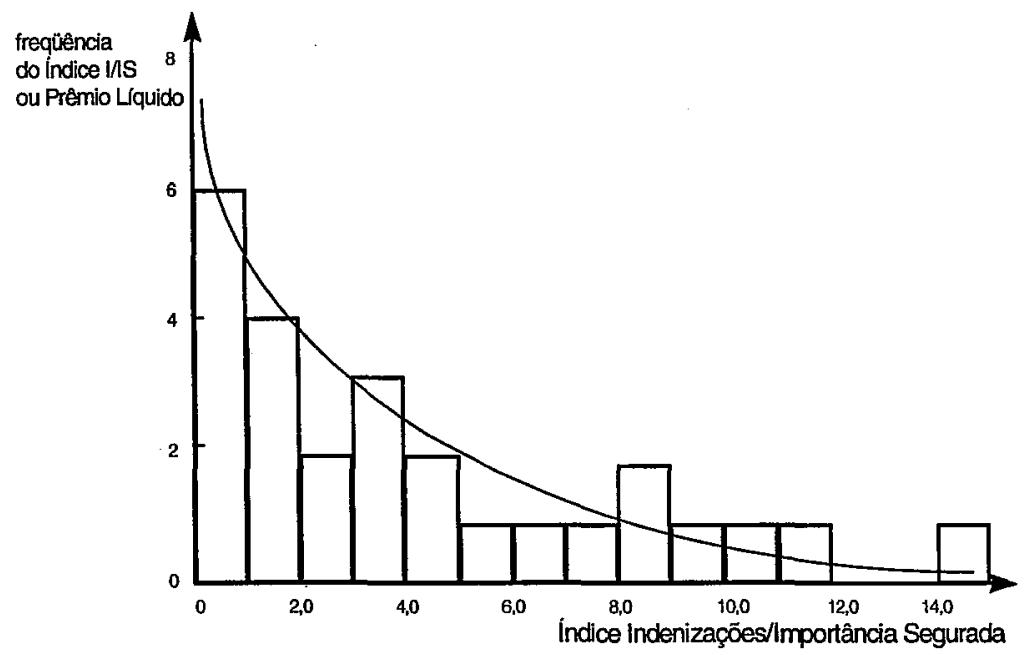

fonte: (Dados obtidos na South-eastem Hail Conference, Attanta, Georgia, USA) op. cit. in RAY (1980)

Figura 6. Curva de distribuição de freqüência do Índice $1 / 1 S$ ou prêmio líquido.

No caso de vendaval, observa-se uma elevação histórica do I/IS ou prêmio líqüido. Na Figura 7, pode-se notar uma gradual elevação do índice, devido ao aumento nos custos de reparos e reposições das propriedades ao longo do tempo. Entretanto, para uma análise rigorosa, deve-se estabelecer a tendência desse crescimento, uma vez que a variação do I/IS calculada diretamente vai de 0,6 a 23,9\%, enquanto a variação tendencial oscila entre 2,2 e 11,82\%, com desvio-padrão de $3,69 \%$ e coeficiente de variação $53 \%$. 


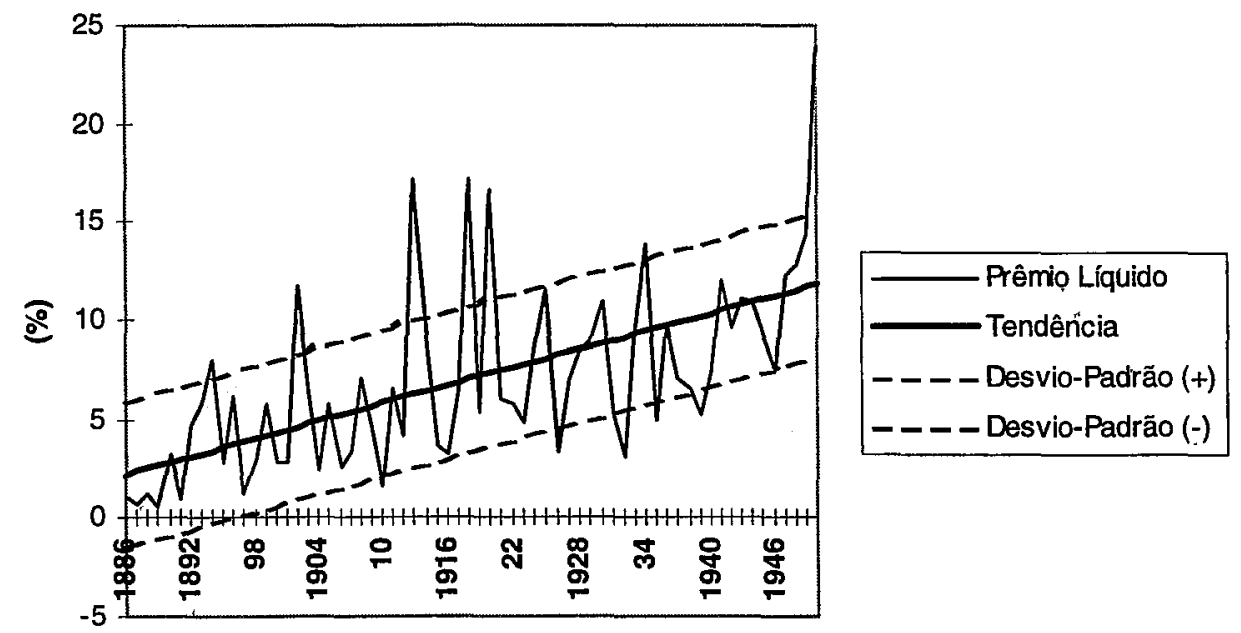

Fonte: (Agricultural Information Bulletin, USDA, n. 56, June 1951; n. 70, Jan., 1952) op. cit. i (1980).

Figura 7. Índice Indenizações/Importância Segurada ou prêmio líqüido, com a tendência de crescimento

Note-se que essas medidas de desempenho fornecem dados para estabelecer parâmetros para o futuro, podendo ser utilizadas para calcular prêmios, indenizações, fundos de reservas etc.

Como a finalidade desta seção foi apresentar as medidas mais usuais que contribuirão para o entendimento das análises posteriores, um aprofundamento neste assunto deve ser procurado em RAY (1981), que pesquisou outros métodos de avaliação de resultados mais específicos e complexos, como por exemplo o método da curva normal, atualmente utilizado nos EUA. 
4 SEGURO RURAL NO BRASIL: EVOLUÇÃO E PERSPECTIVAS 


\section{SEGURO RURAL NO BRASIL: EVOLUÇÃO E PERSPECTIVAS}

\subsection{Histórico ${ }^{12}$}

$\mathrm{Na}$ Idade Média, a propriedade era privilégio do Estado e da aristocracia. Com a divisão da propriedade e a liberdade do comércio, criou-se a necessidade de proteção patrimonial através da força do agrupamento em associação.

Segundo trabalho de Cheriac, em 1671, os seguros foram idealizados pelos judeus em 1182 na Itália e tomaram maior vulto por ocasião das navegações italianas no século XIV. Com a teoria das probabilidades desenvolvida por Pascal em sua obra "Geometria do Espaço", em 1662, deu-se início aos cálculos de riscos.

Uma das mais famosas seguradoras, a Lloyd's, originou-se em $1668 \mathrm{em}$ Londres. O Lloyd's Coffea House tornou-se o ponto de reunião entre banqueiros e navegadores, onde eram discutidos seguros de cargas e navios. Em 1871, a Lloyd's transformou-se em órgão de utilidade pública, possuindo o timbre do Tesouro de Londres em suas apólices. Em virtude do desenvolvimento de seus negócios e da necessidade de maior proteção, a Lloyd's criou o resseguro.

Suíça, Dinamarca, Alemanha e França deram impulso aos seguros agropecuários, apenas no século XIX.

${ }^{12}$ Extraído de SÄO PAULO (Estado, 1971) e GÖPFERT (1993). 
No Brasil, tem-se notícia de contratos de seguros marítimos em 1665. Em 1808, o governo autorizou o funcionamento da Cia de Seguros Boa Fé na Bahia, para trabalhar com seguros marítimos. Em 1820, foi regulamentado o seguro no Brasil. Em 1850, foi promulgado o código comercial, contendo vários artigos que disciplinariam os seguros em geral. Em 1855, implantou-se o seguro de vida no Brasil, com a autorização de funcionamento da Tranqüilidade Cia. de Seguros de Vida.

Com a república, foi criada a Superintendência Geral de Seguros, subordinada ao Ministério da Fazenda. Em 1916, foi promulgado o código civil brasileiro, nele constando vários artigos de regulamentação do seguro no Brasil.

A securidade agrícola no Brasil iniciou-se no Estado de São Paulo, quando a cultura algodoeira se expandia e a Secretaria da Agricultura, através do Instituto Agronômico de Campinas (IAC), possuía o monopólio de produção de sementes de algodão, estabelecendo, na composição do preço de venda das sementes, uma parcela significativa referente ao prêmio pelo seguro contra granizo.

O Decreto $n^{\circ} 9.865$ de 27 de dezembro de 1938 deu competência ao IAC para comprar e vender sementes de algodão, cobrar o prêmio, vistoriar e pagar indenizações. Em outubro de 1939, o Decreto no 10.554 veio disciplinar as normas do seguro, constituindo o Fundo de Defesa da Lavoura Algodoeira.

Também em 1939, com a finalidade de evitar a evasão de lucros do Brasil para outros países e nacionalizar a atividade seguradora, foi criado o Instituto de Resseguros do Brasil (IRB), do qual a União era acionista e cuja função foi regulamentar as operações, obrigando as sociedades e companhias de seguros a ressegurar suas responsabilidades excedentes no próprio instituto.

Dado o grande desenvolvimento do seguro paulista, em 1942 foi criada, sob a forma de fundos, a Carteira de Seguro Contra o Granizo. Os saldos positivos durante a primeira década de funcionamento permitiram à Secretaria da Agricultura do Estado de 
São Paulo implementar o desenvolvimento técnico-agronômico em outras áreas da agropecuária.

O sucesso da carteira levou à sua primeira diversificação, originando a Carteira Agrícola de Seguros Contra o Granizo para os Viticultores de São Paulo, criada pela lei 111 de julho de 1948.

O Decreto n 18.437 de dezembro de 1948 criou a Comissão de Produção Agropecuária, subordinada à Secretaria da Agricultura do Estado de São Paulo, cujo objetivo principal era o desenvolvimento da produção agropecuária. Em 1950 e 1952 ', as carteiras de seguro de granizo para algodão e uva passaram a ser subordinadas à comissão. Embora esse pionerismo tenha alcançado seus objetivos, além de desenvolverem-se importantes estudos atuariais, não foi constituída uma companhia de seguros nem o resseguro das operações, ficando todo o risco sob a responsabilidade do governo estadual, através da Comissão de Produção Agropecuária.

Em janeiro de 1954, foi votada a Lei $n^{\circ} 2.168$, que instituía e disciplinava o seguro agrícola e pecuário para cobertura de riscos peculiares a essas atividades em nível nacional. A lei deu competência ao IRB para desenvolver estudos, levantamentos e planejamentos para a criação do seguro agrário em todo o país, fixando condições das apólices e valores das tarifas de prêmios. Criaram-se, também, o Fundo de Estabilidade do Seguro Agrário, que seria administrado pelo IRB, e a Companhia Nacional de Seguros Agrícolas (CNSA).

O Fundo de Estabilidade do Seguro Agrário tinha a finalidade de ressegurar as operações das companhias seguradoras no ramo agrícola. As companhias efetuavam o pagamento de quantia correspondente aos lucros excedentes do máximo admissivel tecnicamente nas suas operações agrárias e o fundo reembolsava os prejuízos excedentes do máximo tecnicamente admissível. 
O fundo também contava com os seguintes recursos:

. $50 \%$ dos dividendos da União, como acionista do IRB;

. contribuições e participações nas operações instituídas pelo IRB.

Para os dez anos seguintes, o Fundo contaria com:

. dotação orçamentária da União;

- 10\% dos lucros líqüidos dos estabelecimentos bancários que financiavam a agropecuária, pertencentes à União;

. contribuições de estados e municípios.

$x$

A Companhia Nacional de Seguros Agrícolas (CNSA) possuía uma composição acionária distribuída entre a União (30\%), entidades de economia mista e bancárias, resseguradoras, autarquias destinadas ao fomento da lavoura $(50 \%)$ e sociedades de seguro e capitalização (20\%). A CNSA também criou, além de seus fundos e reservas normais, um Fundo de Estabilidade, para manter o nível das tarifas e prêmios em bases razoáveis e atender casos de catástrofes.

A Lei $n^{\circ}$ 2.168, mencionada acima, não interferiu no seguro agrícola do Estado de São Paulo, pois manteve em vigor as legislações federal e estadual, exceto os pontos que colidissem com seus preceitos.

Em abril de 1954, o Decreto no 35.409 aprovou os estatutos da CNSA e estabeleceu reservas e fundos para a garantia das operações:

. Reservas de Riscos Não-Expirados;

. Reservas de Sinistros a Liqüidar;

. Reservas de Contingência;

. Fundo de Garantia de Retrocessões;

. Fundo de Estabilidade;

. Fundo de Oscilações de Títulos.

Embora tenha ficado evidente o esforço no desenvolvimento do seguro rural, através de subvenções à companhia, os resultados não foram satisfatórios. $\mathrm{Na}$ 
tentativa de melhorar o desempenho da CNSA, em 1962, o Decreto 1.224 de junho de 1962 obrigou a contratação de seguro rural a todos os produtores que financiassem suas atividades em bancos com participação total ou parcial da União, como Banco do Brasil, Banco do Nordeste, Banco Nacional de Crédito Cooperativo, tornando-os beneficiários dos seguros.

Com relação ao Estado de São Paulo, o governo estadual sancionou a Lei no 8.375 em outubro de 1964, criando a Carteira Agrícola de Seguros Contra a Geada para os Horticultores, Floricultores e Fruticultores. No mesmo mês, a lei $n^{\circ} 4430$ veio socorrer o seguro rural no Brasil, através dos seguintes atos:

- elevou o capital da CNSA em um bilhão de cruzeiros, cujos subscritantes seriam a União e outros acionistas;

. contemplou o Fundo de Estabilidade administrado pelo IRB com dotações para os próximos dez anos, de modo a manter 100.000 cruzeiros reais anuais;

. aumentou para um bilhão de cruzeiros o Fundo de Estabilização da CNSA em ser integralizados pela União nos dez anos subseqüentes;

. permitiu à CNSA operar com os demais seguros;

. autorizou a CNSA a fixar prêmios que anteriormente estavam sob responsabilidade do IRB;

. transferiu a CNSA para o Ministério da Agricultura.

Em novembro de 1966, a CNSA foi dissolvida pelo Decreto-Lei $n^{\circ}$ 73, e seu fracasso pode ser resumido às seguintes observações, segundo GÖPFERT et al. (1993):

. não-disseminação do seguro facultativo;

. não-operação em áreas mais rentáveis;

. injunções políticas, alterando constantemente sua orientação;

. falta de estrutura técnica-agronômica de apoio;

. ocorrência de eventos generalizados. (de 1960 a 1965, houve ocorrência de geadas generalizadas no sul do país (subseção 4.2.2). 
A partir de 21 de novembro de 1966, através do mesmo Decreto-Lei oㅜ 73, todas as operações de seguros privados realizadas no Brasil ficariam subordinadas aos seus artigos, marcando a divisão de duas épocas distintas do seguro rural nacional. Esse decreto continua regendo os seguros privados atualmente.

Instituiu-se então, o Sistema Nacional de Seguros Privados, através do qual o governo federal formularia políticas de seguros privados, estabeleceria as normas gerais e fiscalizaria as operações no mercado brasileiro. O Sistema Nacional de Seguros Privados foi constituído pelos seguintes órgãos:

- Conselho Nacional de Seguros Privados - CNSP;

- Superintendência de Seguros Privados - SUSEP;

- Instituto de Resseguros do Brasil - IRB;

- Sociedades autorizadas a operar em seguros privados;

- Corretores habilitados.

Foi criado também o Fundo de Estabilidade do Seguro Rural, com a finalidade de garantir estabilidade ao sistema e atender a cobertura suplementar dos riscos de catástrofes. Seus recursos originaram-se de:

- excedentes do máximo admissivel tecnicamente, como lucro nas operações de seguros de crédito rural, seus resseguros e suas retrocessões, segundo limites fixados pelo CNSP;

. dotações orçamentárias anuais para os próximos dez anos, mediante crédito especial, necessário para cobrir a deficiência operacional do exercício anterior;

- recursos previstos no artigo 23 do Decreto-Lei. $O$ artigo 23 determina que os seguros dos bens, direitos, créditos e serviços dos órgãos do Poder Público, bem como os de bens de terceiros que garantam as operações dos ditos órgãos, serão contratados com seguradoras, mediante sorteio. As comissões de corretagem admitidas pelo CNSP deverão ser recolhidas ao IRB, para crédito do Fundo de Estabilidade do Seguro Rural;

. foram incorporados também os saldos dos Fundos de Estabilidade do Seguro Agrário. 
Estabeleceu-se a obrigatoriedade do seguro rural vinculado a contratos de crédito realizados por instituições financeiras pertencentes ao Sistema Nacional de Crédito Rural, tornando-as beneficiárias até o pagamento do financiamento.

As principais atribuições do Conselho Nacional de Seguros Privados - CNSP foram:

. fixar diretrizes e normas da política de seguros privados;

- regular a constituição, organização, o funcionamento e a fiscalização dos que exercerem atividades subordinadas a esse Decreto-Lei, bem como a aplicação de penalidades;

- estipular índices e demais condições técnicas sobre tarifas;

. fixar características gerais dos contratos de seguros;

. fixar normas gerais sobre contabilidade e estatísticas para as sociedades seguradoras;

. determinar o capital do IRB e das sociedades seguradoras;

. estabelecer diretrizes para as operações de resseguro;

- prescrever critérios de constituição de sociedades seguradoras, com fixação de limites técnicos e legais das operações;

. disciplinar a corretagem de seguros e a profissão do corretor;

. outros.

O CNSP foi composto dos seguintes membros:

. Ministro da Indústria e Comércio - Presidente;

. Ministro da Fazenda ou seu representante;

. Ministro da Saúde ou seu representante;

. Ministro do.Trabalho ou seu representante;

. Ministro da Agricultura ou seu representante;

. Superintendente da SUSEP;

. Presidente do IRB;

. outros. 
À Superintendência de Seguros Privados - SUSEP competia principalmente:

. executar a política traçada pelo CNSP como órgão fiscalizador das sociedades seguradoras:

. processar pedidos de autorização para constituição das sociedade seguradoras;

. fixar condições de apólices e tarifas a serem utilizadas;

. aprovar limites de operações das sociedades seguradoras;

. outros.

Ao Instituto de Resseguros do Brasil - IRB competia:

. regular co-seguro, resseguro e retrocessão;

- promover o desenvolvimento das operações de seguro;

. administrar os recursos do FESR.

O governo do Estado de São Paulo, além das carteiras contra granizo praticadas pela Comissão de Produção Agropecuária, operava também com outros tipos de seguro através do Serviço Autônomo de Seguros, vinculado ao Instituto de Previdência do Estado de São Paulo (IPESP), no qual eram segurados os bens do estado.

Para adequar-se ao Decreto-Lei n 73, o governo de São Paulo autorizou o IPESP a constituir, em sociedade anônima, o Serviço Autônomo de Seguros, formado por:

. Companhia Paulista de Estradas de Ferro;

- Viação Aérea de São Paulo - VASP;

. Centro de Abastecimento S.A. - CEASA;

. Companhia Mogiana de Estradas de Ferro;

- Companhia de Armazéns Gerais do Estado de São Paulo CAGESP;

COTESP;

- Companhia de Telecomunicações do Estado de São Paulo . Companhia Agrícola de Imigração e Colonização - CAIC. 
Assim, em 1967, nasceu o IPESP - Seguros Gerais S.A., passando mais tarde (1969) a denominar-se Companhia de Seguros do Estado de São Paulo (Cosesp). A Secretaria da Agricultura deixou de ser seguradora, passando a ser estipulante através da Coordenadoria de Assistência Técnica Integral (CATI), contratando seguros e realizando inspeções periciais.

Em julho de 1970, o Conselho Nacional de Seguros Privados aprovou as seguintes modalidades de cobertura para seguros agropecuários:

- Seguro Agrícola: destinado a operações de custeio agrícola, cobrindo perdas decorrentes de fenômenos meteorológicos, pragas e doenças incontroláveis;

. Seguro Pecuário: destinado aos financiamentos da espécie, indenizando a morte decorrente de acidentes ou doenças;

- Seguro de Bens, Benfeitorias e Produtos Agropecuários: destinado a financiamentos de investimentos, pré-comercializações e outros, como de construções, instalações e equipamentos fixos, safras removidas, veículos rurais mistos ou de carga, máquinas e implementos agrícolas etc.;

- Seguro Temporário de Vida: destinado à garantia de liqüidação dos financiamentos concedidos ao pequeno produtor no caso de morte do financiado.

Em janeiro de 1972, o governo do Estado de Minas Gerais aprovou a criação de um seguro agrícola a ser operado pela Companhia de Seguros de Minas Gerais (COSEMIG), posteriormente submetido ao CNSP. O apoio técnico foi realizado pela Associação de Crédito e Assistência Rural (ACAR), contando com 1.500 servidores em 94\% dos municípios mineiros. Em 1974, a companhia passou a ser denominada BEMGE - Companhia de Seguros de Minas Gerais e, em 1975, a ACAR foi transformada na Empresa de Assistência Técnica e Extensão Rural do Estado de Minas Gerais (EMATER-MG).

Concomitantemente ao desenvolvimento dos seguros privados, em dezembro de 1973, pela lei 5.963, foi criado o Programa de Garantia da Atividade Agropecuária (Proagro), administrado pelo Banco Central, cujo regulamento está especificado no 
Capítulo 7 do Manual de Crédito Rural (BANCO CENTRAL, 1992, seção 8). Os objetivos do programa eram:

. "exonerar o produtor rural de obrigações financeiras relativas à operação de crédito rural de custeio e/ou investimento e para cujo cumprimento venha a ficar impedido pela ocorrência extraordinária de fenômenos fortuitos da natureza, pragas e doenças que prejudiquem rebanhos e plantações";

. "atuar como instrumento de incentivo à utilização de tecnologia adequada à exploração agropecuária, à medida que esta tecnologia encontre apoio nos meios de produção (insumos modernos, máquinas etc.) previstos nos respectivos instrumentos de crédito rural, a par, naturalmente, da orientação dos serviços de assistência técnica aos produtores rurais".

\subsection{Situação Atual}

\subsubsection{Cosesp}

Para adequar-se ao Decreto-Lei no 73, o governo de São Paulo criou, em junho de 1967, o IPESP - Seguros Gerais S.A., que deu origem à Cosesp em junho de 1969.

O Conselho Nacional de Seguros Privados aprovou, em julho de 1970, as seguintes modalidades de cobertura: Seguro Agrícola, Seguro Pecuário, Seguro de Bens, Seguro Temporário de Vida.

$\mathrm{Na}$ década de 70 , apenas quatro anos apresentaram resultados finais positivos em relação à sinistralidade (índice sinistro/prêmio), ou seja, o valor em prêmios arrecadados superou o valor pago em indenizações (seção 3.2). 
Observa-se na Figura 8 que, na década de 80 , apenas dois anos apresentaram resultados positivos em relação à sinistralidade; nos demais, nota-se elevação gradual dos resultados negativos, explicada talvez como uma maneira de compensação encontrada por alguns produtores devido ao esgotamento da política de subsídios e, conseqüentemente, ao aumento das taxas de juros, gerando dificuldades para liqüidação dos financiamentos.

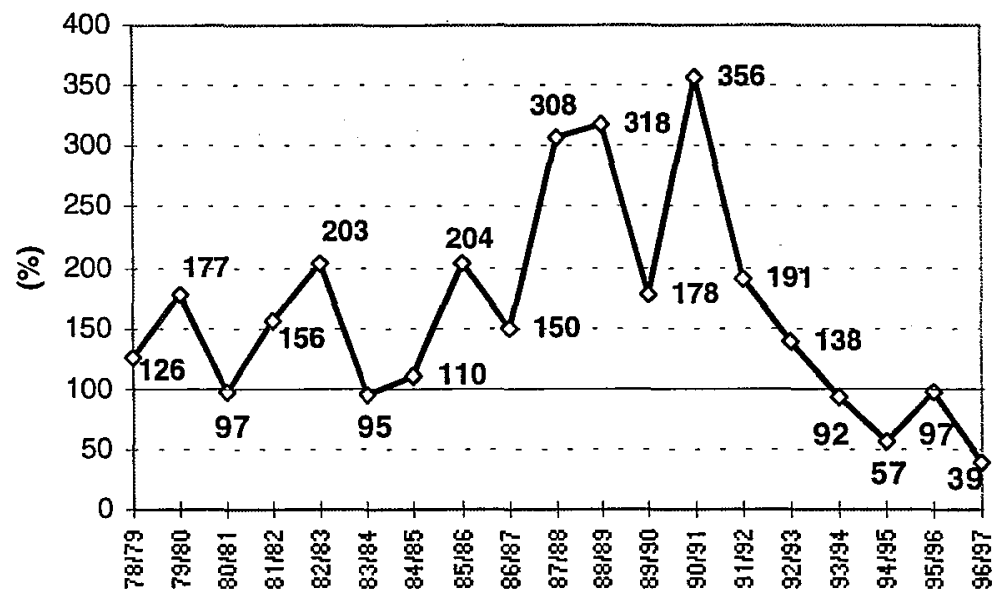

fonte: Cosesp

$\multimap-$ indice sinistro/prêmio

Figura 8. Índices Sinistro/Prêmio (sinistralidade) da Cosesp, entre ciclos agrícolas de $78 / 79$ e $96 / 97$.

Para uma seguradora estatal, que tem a finalidade política de manter estável o nível de renda dos produtores do estado, o índice de sinistralidade de $100 \%$ seria satisfatório. Pode-se notar a reversão de tendência a longo prazo que a Cosesp alcançou.

Nos últimos quatro ciclos agrícolas, 93/94, 94/95, 95/96 e 96/97, os resultados passaram a ser positivos devido à austeridade administrativa e à forte diminuição no número de seguros realizados pela companhia, conforme mostrado na Figura 9. 


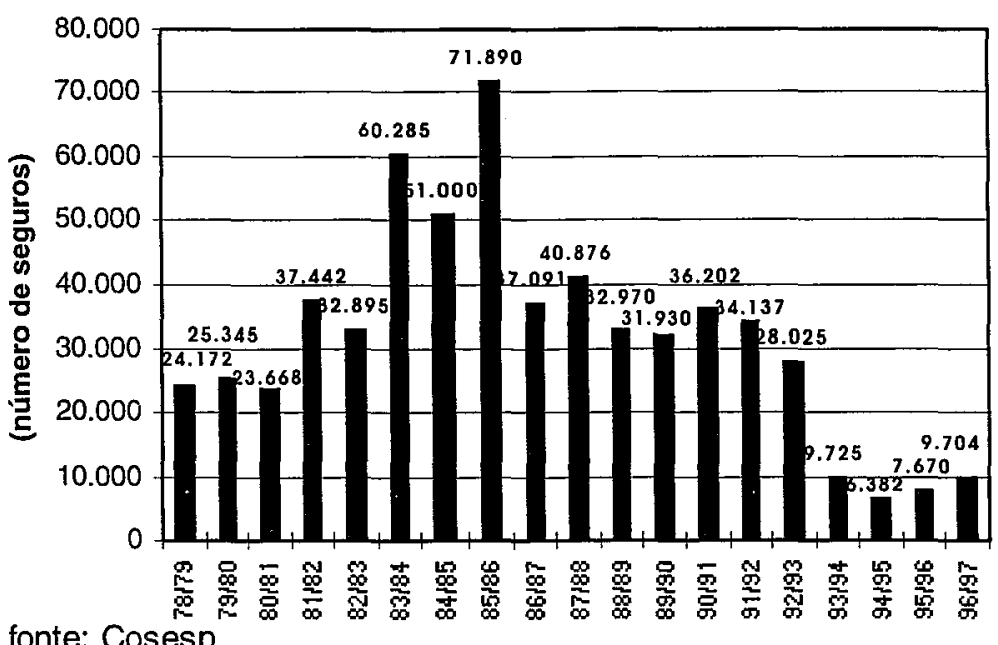

fonte: Cosesp

Figura 9. Seguros agrícolas realizados na Cosesp, entre os ciclos agrícolas 78/79 e 96/97

Em 1991, produtores de algodão, pressionados por altos valores de custo de produção, reivindicaram à Secretaria da Agricultura do Estado de São Paulo a diminuição no preço da semente, vendida sob forma de monopólio desde 1934. Para atender aos produtores, a secretaria retirou do preço da semente a obrigatoriedade do pagamento do prêmio do seguro, nele embutido. Segundo MARTINS (1991), o seguro do algodão apresenta claras vantagens sobre o Proagro, segurando a receita esperada e não apenas o Valor Básico de Custeio (VBC).

Nos últimos três ciclos agrícolas, indicadores como número de seguros agrícolas e número de seguros facultativos aumentaram, enquanto o índice sinistro/prêmio ou sinistralidade permaneceu sempre abaixo de $100 \%$, demonstrando a tendência de rentabilidade positiva da única companhia de seguros que opera no setor rural em grandes volumes.

De acordo com a Diretoria de Seguro Rural da Cosesp, houve redução nas taxas de prêmio entre os ciclos agrícolas 94/95 a 97/98 para as seguintes culturas: 
feijão, de 14 para 9\%; uva (granizo), de 14 para 3\%; milho (taxas regionalizadas), de 16 para $5 \%$; e soja (taxas regionalizadas), de 16 para $5 \%$; respectivamente.

Atualmente, a Cosesp oferece aos agricultores paulistas os seguintes seguros rurais ${ }^{13}$ :

(a) Seguro Agrícola

Do plantio à colheita, cobre os prejuízos causados por tromba d'água, ventos fortes, ventos frios, granizo, chuvas excessivas, seca, geada, incêndio, raio, variação excessiva de temperaturas. Pode-se contratá-lo exclusivamente para granizo e geada.

As culturas cobertas, com as respectivas taxas de prêmio, são: amendoim das águas (15\%) e da seca (15\%); arroz irrigado pré-germinado (12\%), plantio por mudas $(12 \%)$ e por semeadura (16\%); cana-de-açúcar $(1,5 \%)$; cebola muda e soqueira - bulbinho (4,5\%); feijão irrigado (4\%) e sequeiro (9\%); mandioca $1^{\circ}$ ciclo e $2^{\circ}$ ciclo $(5 \%)$; milho silagem $(7 \%)$; milho safrinha $(10 \%)$, safrinha irrigado $(8 \%)$ e verde $(8 \%)$; trigo irrigado (7,5\%) e sequeiro (15\%); vagem (6\%); algodão (4 a $11 \%)$; batata inglesa (5 a $11 \%)$; milho (5 a $10 \%$ ); soja (5 a $7 \%$ ); tomate envarado (6 a $10 \%)$; tomate rasteiro (8 a 10\%). Nota-se que algumas culturas têm as taxas de prêmios regionalizadas de acordo com o risco que oferece cada município, caracterizando um zoneamento para o Estado de São Paulo.

A porcentagem de cobertura no caso de perda total varia de acordo com os estágios de desenvolvimento da cultura, podendo cobrir até $100 \%$ do financiamento ou do orçamento de custeio. Entende-se como orçamento de custeio o levantamento das despesas necessárias à aquisição de sementes ou mudas, outros insumos e despesas com tratos culturais, do plantio à colheita. No caso de perda parcial, apura-se o prejuizo estimado em laudo técnico, diminuindo-se a franquia de $5 \%$ da porcentagem

\footnotetext{
${ }^{13}$ Extraído de SEGURO AGRíCOLA COSESP (1996 e 1997).
} 
alcançada, aplicando o resultado no valor máximo segurado, cujo total será a indenização devida.

\section{Exemplo:}

. Cultura de soja em Ribeirão Preto, SP, com tecnologia A;

. Área plantada: 10 ha;

. Valor segurado/há $=R \$ 400,00$; valor segurado total $R \$ 4.000,00$;

. Taxa de prêmio $5 \%$, que corresponde a $\mathrm{R} \$ 200,00$;

. Perda parcial de $60 \%$ (apurada no laudo), que deverá ter diminuição de $5 \%$ referente à franquia;

. Indenização devida $=\mathrm{R} \$ 4.000,00 \times 55 \%=\mathrm{R} \$ 2.200,00$

(b) Seguro Porteira Fechada

Garante a segurança de bens e benfeitorias, produtos agropecuários colhidos, máquinas e implementos agrícolas, veículos rurais mistos ou de cargas, vinculados ou não a operações bancárias. Garante perdas causadas por incêndio, explosão, raio e suas conseqüências, vendaval, impacto de veículo, desmoronamento, tremores de terra, ação mecânica do granizo, colisão, roubo.

Os bens cobertos, com as respectivas taxas de prêmios, são: produtos agropecuários colhidos ou abatidos, beneficiados, transformados ou não $(0,35 \%)$; benfeitorias $(0,5 \%)$; sacarias, embalagens e recipientes $(0,35 \%)$; mudas e sementes, corretivos, fertilizantes, defensivos, rações $(0,35 \%)$; máquinas e implementos agrícolas (1\%); veículos rurais de carga de até $7 \mathrm{t}(3 \%)$; veículos rurais de mais de $7 \mathrm{t}(4 \%)$; veículos rurais mistos (10\%).

\section{(c) Seguro de Florestas}

Garante cobertura de florestas naturais, seringueiras, araucárias e espécies vegetais ecologicamente adaptadas no Brasil, como pinnus, eucaliptos etc., contra 
incêndio, chuvas excessivas, ventos fortes e frios, granizo, geada, seca e raio. A taxa de prêmio varia de 0,8 a $2,8 \%$ da importância segurada.

(d) Seguro de Animais

Segura bovinos, eqüinos e ovinos contra doenças, acidentes, incêndio, raio e outras causas.

(e) Seguro de Vida Rural

Abrange cobertura de morte por qualquer causa, indenização especial por acidente, indenização permanente, total ou parcial por acidente, invalidez total por doença, inclusão do cônjuge na forma automática, auxílio cesta básica e auxílio educação.

No ano de 1997, a Cosesp foi autorizada a efetuar seguro agrícola, primeiramente para milho e soja, no Estado do Paraná, cobrindo chuvas excessivas, geada, granizo, incêndio e raio, seca, tromba d'água, variação excessiva de temperatura e ventos fortes e frios. A taxa de prêmio para milho, cuja época de plantio vai de 01/09 até $15 / 11$, é de $6,5 \%$, e para soja, com plantio permitido entre $1 / 10$ até $31 / 12,5,5 \%$. Há possibilidade de no futuro de expandir suas atividades para o Rio Grande do Sul.

Os valores máximos das coberturas de seguros facultativos, em reais, para milho e soja no Paraná, ficam aproximadamente entre $R \$ 5$ e $7 / \mathrm{sc}$ e $R \$ 10$ e $12 / \mathrm{sc}$, respectivamente, cobrindo perfeitamente o custo de produção.

Ultimamente, a Cosesp vem esforçando-se, técnica e politicamente, para garantir o fluxo de recursos que alimentam o Fundo de Estabilidade do Seguro Rural (FESR). O princípio básico que deve ser aplicado a qualquer tipo de seguro, principalmente no setor rural, é a manutenção de um lastro financeiro para garantia do sistema em anos que apresentem eventos generalizados em níveis catastróficos. Essa 
garantia pode ser válida se a União, através do Tesouro Nacional, assumir a responsabilidade. No caso brasileiro, para que o governo não tivesse a responsabilidade total sobre os riscos catastróficos, foi criado, através do Decreto-Lei n. 73 , de novembro de 1966, o Fundo de Estabilidade do Seguro Rural (FESR), com a finalidade de garantir um lastro financeiro ao sistema segurador e atender a cobertura suplementar dos riscos de catástrofes. Seus recursos originavam-se, de:

. excedentes do máximo admissível tecnicamente, como lucro nas operações de seguros de crédito rural, seus resseguros e suas retrocessões, segundo limites fixados pelo CNSP;

- dotações orçamentárias anuais para os próximos dez anos, mediante crédito especial, necessário para cobrir a deficiência operacional do exercício anterior;

- recursos previstos no artigo 23 do Decreto-Lei: o artigo 23 determina que os seguros dos bens, direitos, créditos e serviços dos órgãos do Poder Público, bem como os de bens de terceiros que garantam as operações dos ditos órgãos, serão contratados com seguradoras, mediante sorteio. As comissões de corretagem admitidas pelo CNSP deverão ser recolhidas ao IRB, para crédito do Fundo de Estabilidade do Seguro Rural.

Porém, em junho de 1993, a Lei das Licitações n 8.666, extinguiu o artigo 23 do Decreto Lei no 73 de novembro de 1966, uma vez que as contratações dos seguros dos bens, direitos, créditos e serviços dos órgãos do Poder Público obedeciam o regime de sorteio e não por intermédio de licitação. Com a revogação do artigo 23 , desapareceram também os fluxos de recursos provenientes das comissões de corretagem das contratações de seguros do Poder Público, canalizados para crédito do FESR.

Contrária ao corte do fluxo de recursos para o FESR, a Cosesp iniciou, em janeiro de 1996, uma minuciosa estratégia de esclarecimento a políticos e juristas, 
chamando a atenção para a importância de se constituir um fundo garantidor das seguradoras agropecuárias em anos difíceis. Através de ofícios, pareceres, estudos técnicos etc., a Cosesp deu subsídios na composição do Projeto de Lei do Senado nº 295 (complementar), de 1995, do senador Edson Lobão, que permanece em tramitação no Senado (esse Projeto de Lei será detalhado na subseção 4.2.4).

\subsubsection{Proagro $^{14}$}

De acordo com o sistema de administração e as fontes de recursos, o Proagro pode ser dividido em dois períodos: Proagro Velho, que compreende o período que vai de janeiro de 1975 até agosto de 1991, e Proagro Novo, considerado a partir de agosto de 1991, com a publicação da Resolução do Conselho Monetário Nacional 1855, do Decreto 175, baseado na Lei 8.171, de 17 de janeiro de 1991, conhecida como Lei Agrícola. Esses dois períodos serão discutidos à seguir:

- Proagro Velho

O Proagro foi criado pela lei $n=5.963$ de dezembro de 1973 e suas atribuições foram descritas anteriormente, na seção 4.1. Cobria somente riscos de empreendimentos financiados com recursos do crédito rural de custeio e investimento, até o volume de $80 \%$ do financiamento, e era sustentado pela taxa de risco (prêmio), estabelecida em $10 \%$, sendo $9 \%$ assumidos pelo Tesouro Nacional e apenas $1 \%$, pelo produtor, recolhido em um fundo único, de onde eram retirados os pagamentos.

\footnotetext{
${ }^{14}$ Extraído de GÖPFERT (1993), TARTAROTTI (1995) e de pareceres e entrevistas com agentes do setor de seguros agropecuários.
} 
Segundo MARTINS (1985), o Proagro buscou proteger o sistema financeiro que participava do Sistema Nacional de Crédito Rural ${ }^{15}$, visto que a cobertura limitavase ao valor concedido de financiamento $\left(\mathrm{VBC}^{16}\right)$ e o beneficiário do seguro era a instituição financeira. A grande maioria dos produtores que não possuíam acesso ao crédito rural não poderiam participar do programa. Anos de escassez de financiamentos agropecuários (1983) tiveram um volume de contratos de Proagro proporcionalmente menores.

O Programa inicialmente foi administrado pela Diretoria de Crédito Rural do Banco Central e normatizado pela CMN. Atribuiu-se ao Poder Executivo a criação da Comissão Especial de Recursos (CER), responsável por analisar e decidir sobre solicitações não-resolvidas relativas ao pagamento de indenizações. As reivindicações de pedidos de reconsideração eram responsabilidade do Bacen, em primeira instância e, em segunda e última instâncias da CER. Posteriormente, as instituições financeiras, que enquadravam as operações e comprovavam os prejuízos, tornaram-se a primeira instância de decisão sobre os pedidos de cobertura, quando o Bacen e a CER tornaram-se segunda e terceira instâncias decisórias, respectivamente.

Em 1979, a legislação do programa foi alterada, estabelecendo que o prêmio deveria ser fixado pelo Conselho Monetário Nacional e que a cobertura aumentaria para $100 \%$ sobre o crédito rural e os recursos próprios dos produtores.

\footnotetext{
${ }^{15}$ O Sistema Nacional de Crédito Rural foi criado em 1965, utilizando-se do crédito rural farto e subsidiado como instrumento de política agrícola, tendo como objetivo: introduzir novas tecnologias; acelerar a formação de capital no meio rural; facilitar o custeio e a comercialização agropecuária; aumentar a produção de alimentos.

${ }_{16}$ Valor Básico de Custeio (VBC): o crédito rural é fornecido de acordo com o nível de tecnologia, que cada produtor deverá aplicar no empreendimento, ao qual está relacionado um Valor Básico de Custeio correspondente. Como o VBC faz parte dos cálculos de liberação do financiamento concedido pelo Sistema Nacional de Crédito Rural, foi utilizado para limitar o crédito rural em anos de escassez de recursos, apresentando sistematicamente valores abaixo do necessário para custear o empreendimento.
} 
Nos primeiros 13 anos de operação, 1973 a 1987, apenas 1985 foi superavitário. O total de receitas no período chegou a US $\$ 0,924$ bilhão e o total de despesas alcançou US\$2,681 bilhões, um prejuízo de US\$1,756 bilhões para o Tesouro Nacional.

De acordo com o levantamento efetuado por MARTINS (1985), a razão entre a somatória dos prêmios recebidos e a somatória das indenizações pagas foi $50 \%$ em 1981, 49\% em 1982, 37\% em 1983 e 57\% de janeiro a setembro de 1984 o que daria uma sinistralidade de $200 \%, 204 \%, 270 \%$ e $175 \%$, respectivamente. Nota-se que a cobertura desses sucessivos déficits canalizava grandes quantidades de recursos do Tesouro Nacional.

Em 1987, como uma das propostas da Nova República, foi constituída uma comissão que elaborou uma nova sistemática, tornando-o mais abrangente e desvinculando-o do crédito rural. Aquele ano, muitos produtores estavam desestimulados a captar recursos de crédito rural, devido às altas taxas de juros à correção monetária. Seria oportuna a restruturação do Proagro, visto que poderiam sentir-se incentivados a aplicar recursos próprios.

Em janeiro de 1988, a administração do Proagro dividiu-se entre o Bacen, que o administrava a contento, e a Secretaria do Tesouro Nacional, com os recursos incluídos no Orçamento Geral da União.

Podem-se considerar duas fases distintas do Proagro Velho nesse período. A primeira (1973 - 1988) possuía total dependência do Tesouro Nacional e a segunda (1988 - 1991) era caracterizada pela extinção da "conta movimento e pelas limitações de previsões de despesas para o ano seguinte, impostas pela Lei de Diretrizes Orçamentárias".

Em 1989, o Bacen parou de efetuar o pagamento das indenizações determinadas pelos técnicos do Proagro. Em contrapartida, o Banco do Brasil suspendeu o recolhimento dos prêmios cobrados dos produtores ao Tesouro Nacional, 
como forma de minimizar a falta de pagamento, por parte do Tesouro, às suas operações de crédito sinistradas, uma vez que o banco vinha saldando as operações por conta própria. Em agosto de 1990, ○ Banco do Brasil parou de pagar as indenizações realizadas por conta própria, visto que o Tesouro não mais repassara dotação alguma aos agentes do Proagro, deixando os produtores sinistrados inadimplentes junto ao banco. No mesmo mês, a CER passou a atuar como única instância administrativa para o julgamento de recursos.

No ano de 1991, o Governo Collor, com o objetivo de incentivar o setor rural, autorizou o Tesouro Nacional a disponibilizar recursos da ordem de Cr\$294,37 bilhões, ficando pendentes $\mathrm{Cr} \$ 106,92$ bilhões.

No mesmo ano, foi promulgada a Lei Agrícola no 8.171 de janeiro de 1991, alterando novamente o Proagro, com recursos provenientes de:

. porcentagem dos produtores rurais, prêmios;

. outros recursos alocados no programa;

. receitas auferidas com a aplicação de seus recursos.

O Banco Central voltou a assumir o papel de administração e gestão dos recursos. Foi criado, também, um Comitê Permanente de Avaliação e Acompanhamento do Proagro, constituído por três representantes de entidades de classe rurais, representantes, um de cada órgão, dos Ministérios da Agricultura, Economia, Fazenda e Planejamento, do Bacen e do Banco do Brasil, respectivamente. As atribuições da CER ficaram inalteradas.

O Tesouro Nacional só interviria em situações de ocorrências generalizadas, quando os recursos do Proagro não fossem suficientes. O programa estendeu-se a produtores que se utilizavam de recursos próprios e não só àqueles com acesso ao crédito rural.

As estimativas de recursos calculadas para o pagamento das indenizações do Proagro Velho no Orçamento da União para 1992 atingiram $\mathrm{Cr} \$ 600$ bilhões, para 
uma dívida de $\operatorname{Cr} \$ 130$ a 140 bilhões, mas o volume alocado foi desviado para outras despesas. Em 1993, haviam duas estimativas do montante que deveria ser pago para os produtores em operações pendentes do Proagro Velho, US\$190 milhões e 213 milhões.

\section{- Proagro Novo/}

Foi criado em julho de 1991, pelo Decreto № 175, cuja principal alteração foi a criação de um fundo específico administrado pela Diretoria de Normas do Bacen. A Comissão Especial de Recursos (CER) manteve suas atribuições de analisar pedidos dos produtores, não atendidos pelos agentes financeiros. Os recursos financeiros do programa já haviam sido definidos na Lei Agrícola de janeiro de 1991, devendo-se salientar que só poderiam ser aplicados recursos do Orçamento da União no caso de ocorrência de eventos generalizados, caso contrário, apenas com aprovação do Congresso Nacional.

Já no início do Proagro Novo, foram constatados problemas como atraso no pagamento das indenizações, falta de informações ao setor rural, excessivo aumento das alíquotas, dificuldade técnica e atuarial, entre outros.

O pacote agrícola de 1993 determinou a regularização das dívidas do Proagro Velho e das dívidas junto ao sistema financeiro. As dificuldades naquela época eram:

- quadro técnico reduzido;

. o Bacen não o considerava prioridade;

. coberturas efetuadas com grande atraso;

. inexistente controle das operações e área abrangida pelo Proagro;

. não-obrigatoriedade de utilização tecnológica adequada;

. seguro de empreendimentos com recursos próprios irrisório;

- falta de cálculos atuariais para ajustamento do programa. 
A inexistência de cálculos atuariais ficou evidenciada por ocasião dos términos das safras 91/92 (verão), 92/93 (inverno), 92/93 (verão) e 93/94 (inverno), quando o Proagro teria de ressarcir coberturas com valor maior que as importâncias que estavam sendo geridas pelo Bacen, resultando no atraso no pagamento das indenizações. De acordo com dados levantados pela Comissão Especial de Inquérito do Endividamento Agrícola, as dívidas com o setor agrícola seriam US\$190 milhões referentes ao Proagro Velho e US\$254 milhões ao Proagro Novo em 1993.

Desde sua criação, as taxas de prêmio cobradas pelo Proagro saíram de $1 \%$, em 1979, passando para 4 e 4,75\% para lavouras irrigadas em 1991 e 92, respectivamente. Para lavouras anuais de sequeiro, o prêmio subiu de 8 para $9 \%$ no mesmo período. Para culturas de inverno, os percentuais alcançaram níveis ainda maiores, 12 e 13,7\%. Pode-se notar que o Proagro apresentou alto custo para o produtor rural.

Diante de todas as deficiências na manutenção do programa, que englobavam problemas nas esferas administrativa, política e técnica, foi criado, em março de 1993, o Departamento de Garantia da Atividade Agropecuária (DGAP), cuja atribuição seria a realização de projetos para desenvolver alternativas de prevenção e controle de riscos na agricultura, além de apoio logístico, técnico e administrativo à Comissão Especial de Recursos (CER).

Essa iniciativa produziu, em dezembro de 1993, um importante trabalho sobre riscos agrícolas, "Eventos Generalizados e Securidade Agrícola", coordenado pelo Professor Hélio Göpfert (1993). O projeto foi financiado com recursos do Banco Mundial, tendo como órgão executor o Instituto de Pesquisa Econômica Aplicada (IPEA). Participaram do projeto, técnicos do DGAP e da Universidade de Brasília.

Em resumo, o trabalho calculou estatisticamente os limites inferior e superior do percentual secular de lavouras sinistradas com $95 \%$ de probabilidade, utilizando dados da Companhia de Seguros do Estado de São Paulo (Cosesp) de cinco ciclos 
agrícolas, 1980/81 a 1984/85. Concluiu-se que em nenhum dos anos analisados o percentual de sinistros situou-se dentro do intervalo.

A diferença dos resultados do cálculo atuarial em relação aos valores efetivamente ocorridos revela que o seguro rural não pode receber o mesmo tratamento que qualquer outro tipo de seguro. Os sinistros no setor rural revelam a ocorrência de eventos generalizados, característica fundamental e que diferencia a securidade rural das demais.

Eventos generalizados são ocorrências em que o risco é propagado, isto é, a ocorrência do evento em determinada lavoura pode ser propagado para outras, tanto para vizinhos geográficos como para lavouras distantes. Por exemplo, se uma lavoura de tomates for atacada por uma doença e os equipamentos ou materiais (implementos agrícolas, engradados, etc.) forem utilizados em outras plantações, essas poderão ser infestadas pela mesma doença. Em 1991, no município de Nova Ponte, MG, surgiu em uma lavoura de soja o nematóide do cisto da soja, que se espalhou em muitas regiões do Triângulo Mineiro, Goiás, Mato Grosso e São Paulo, por intermédio de torrões de solo transportados por sapatos, pneus, implementos, sementes etc.

No caso do vizinho geográfico, é mais fácil visualizar um evento generalizado. Quando uma seca atinge determinada propriedade, muito provavelmente atingirá também o vizinho de cerca. Analisando o seguro de automóveis, os eventos são independentes, ou seja, um sinistro no automóvel de seu vizinho não tem nenhuma relação com o seu. No caso de eventos generalizados, tais indivíduos são chamados de vizinhos de risco.

Buscou-se então, uma definição matemáticà para os vizinhos de risco, com o objetivo de estabelecer um índice capaz de avaliar as conseqüências dos eventos generalizados nos limites calculados. Deve-se lembrar que tais limites (inferior e superior) estabelecerão o montante do fundo de estabilidade. 
Para o cálculo do valor do fundo de estabilidade, deve-se utilizar uma probabilidade condicionada, ou seja, a probabilidade de que uma lavoura venha a ser sinistrada, dado que outra também o foi.

O estudo estabeleceu que o limite superior fica afetado por um fator estabelecido pelo número médio de vizinhos de risco e pelo coeficiente médio de correlação entre eles. Também fazem parte do cálculo a estimativa do percentual secular de lavouras sinistradas, o estimador que mede a variabilidade do número de lavouras sinistradas em torno do seu valor médio secular e o número de lavouras expostas ao risco.

A conclusão desta parte do trabalho cita (p. 64): "a dependência probabilística dos eventos sinistrantes (doenças, pragas, adversidades climáticas etc.) torna os modelos atuariais tradicionais impróprios, pois, neles, os eventos sinistrantes (roubo, morte, incêndio, naufrágio etc.) são probabilisticamente independentes, o que não acontece com os equivalentes agrícolas. A realização de pesquisas não só no campo da Teoria das Probabilidades, mas também na área Atuária, no sentido de desenvolver novos modelos estatísticos e atuariais compatíveis com a realidade, é de fundamental importância para a efetiva funcionalidade da Securidade Agrícola Nacional."

Outro resultado interessante foi a constatação de que aproximadamente $90 \%$ de todas as causas de sinistros no país são decorrentes de seca e chuva excessiva, levando à necessidade de se realizar um minucioso estudo dos dados meteorológicos existentes para delimitar as épocas tecnicamente mais recomendadas para o plantio das diversas culturas, município por município.

Em março de 1995 uma auditoria do Tribunal de Contas da União (TCU) apurou que, durante os anos de 1989 a 1993 as receitas do Proagro foram de US\$ 801 milhões, enquanto as despesas alcançaram US\$ 1,5 bilhão, o que revelou um déficit de quase US\$700 milhões. O relatório concluiu que o Programa deveria passar por modificações porque: "não possui controles financeiros adequados; seu sistema operacional é muito vulnerável a fraudes; existem profundos conflitos com relação às 
atividades dos agentes intervenientes; não há a salutar segregação das funções administrativas." (PINHEIRO, 1995, p. 19)

No mesmo mês, o Ministro da Agricultura, do Abastecimento e da Reforma Agrária, em pronunciamento na Comissão de Agricultura da Câmara dos Deputados, disse: "O problema é que o Proagro está mergulhado em graves impasses, que o tornam inviável. Hoje, lamentavelmente, o Proagro pouco interessa ao produtor e não gera segurança alguma para o sistema financeiro. $O$ governo atual herdou uma dívida de 190 milhões de reais de processos deferidos e não honrados durante o chamado Proagro Velho, ou seja, no período anterior a julho de 1991. Quanto ao Proagro Novo, que não conta com repasses do Tesouro Nacional, já se calcula um déficit de 350 milhões de reais. O não-pagamento de tais dívidas junto a produtores, cooperativas e ao sistema financeiro provocou profundo descrédito nesse importante instrumento de política agrícola. Por estas razões, o governo está procedendo a estudos no sentido de rever a participação estatal nesta área” (TARTAROTTI, 1995, p. 7).

Em setembro de 1995, o Ministério da Agricultura autorizou o projeto "Redução de Riscos Climáticos para a Agricultura", coordenado pelo DGAP e realizado pela Fundação de Empreendimentos Científicos e Tecnológicos (Finatec/UNB), Empresa Brasileira de Pesquisas Agropecuárias (EMBRAPA), Instituto Nacional de Meteorologia (INMET), Departamento Nacional de Água e Recursos Hídricos (DNAEE), Instituto Agropecuário Paranaense (IAPAR) e Empresa de Pesquisa Agropecuária e Extensão Rural de Santa Catarina (EPAGRI-SC). O objetivo principal seria a criação do Zoneamento Agrícola Nacional, que permitiria a regionalização das datas de plantio para culturas básicas - trigo, arroz, soja, milho e feijão - em qualquer parte do território nacional.

O Zoneamento Agrícola foi primeiramente implantado na safra de inverno de 1996, na cultura do trigo, para os estados de MS, PR, SC e RS. O voto do CMN de março de 1996 instituiu alíquotas (prêmios) diferenciadas de pagamento ao Proagro, para empreendimentos que respeitassem o zoneamento. Para a safra de verão de 96/97, o voto do CMN de junho de 1996 estabeleceu que as alíquotas de arroz e feijão 
para os estados de GO, TO, MG, SP, MT, MS, PR, SC e RS sejam reduzidas de $11,7 \%$ para $6,7 \%$ e, para milho e soja, de $7 \%$ para $3,9 \%$. As lavouras irrigadas de todos os estados do país teriam redução de $4,7 \%$ para $1,7 \%$. Os programas sociais, como Programa Nacional de Fortalecimento da Agricultura Familiar (Pronaf) e Programa de Crédito Especial para a Reforma Agrária (Procera), e as operações com recursos de Fundos Constitucionais sob a égide do Programa Terra terão alíquotas de $2 \%$, sendo que as irrigadas, $1,7 \%$.

Em junho de 1996, pelo Decreto no 1.947, ficou autorizado ao Tesouro Nacional realizar emissão de títulos para pagamento de dívidas vencidas do Proagro. As dívidas passíveis de pagamento situam-se no período entre 15 de agosto de $1991 \mathrm{e}$ 14 de junho de 1996. Os títulos têm prazo de oito anos com pagamento semestral; serão atualizados mensalmente pelo Índice Geral de Preços - Disponibilidade Externa (IGP-DI) com juros remuneratórios de $6 \%$ ao ano; poderão ser utilizados no mercado secundário e no Programa Nacional de Desestatização. Porém, somente em julho de 1997, com a emissão de $\mathrm{R} \$ 636,98$ milhões em títulos públicos, iniciaram-se o pagamento dos débitos atrazados.

\subsubsection{IRB}

O Instituto de Resseguros do Brasil foi criado pelo governo em 1939, como uma sociedade de economia mista. Sua principal finalidade foi evitar a evasão de lucros do Brasil para outros países e nacionalizar a atividade seguradora. Sua função fora regulamentar as operações de seguros, obrigando as sociedades e companhias de seguros a ressegurar suas responsabilidades excedentes no próprio instituto.

A Lei $n^{\circ} 2.168$ de janeiro de 1954 instituiu e disciplinou o seguro rural brasileiro, autorizando o IRB a realizar estudos, levantamentos e planejamentos para dar subsídios ao desenho das apólices e valores de prêmios. Foi facultado também ao instituto, a administração do Fundo de Estabilidade do Seguro Agrário, recém-criado. 
O Decreto-Lei nํ 73 de novembro de 1966, que dispôs sobre a nova legislação do seguro e resseguro rural, ainda é responsável por todas as normas relacionadas a seguros no Brasil. Estabeleceu que $50 \%$ do capital do IRB seria de propriedade das entidades federais de previdência social e o restante, das sociedades seguradoras.

A lei atribuiu uma série de responsabilidades ao IRB, entre elas:

(a) regulação do co-seguro, resseguro e da retrocessão, devendo:

- elaborar e expedir normas;

- aceitar e reter o resseguro do país e do exterior;

- promover a colocação, no exterior, de seguros que não encontrem cobertura no Brasil;

- impor penalidades;

- organizar e administrar consórcios;

- proceder à liqüidação de sinistros, de acordo com as normas de cada ramo;

- representar as retrocessionárias nas liqüidações de sinistros.

(b) promoção do desenvolvimento das operações de seguro, devendo:

- organizar cursos e promover congressos;

- incentivar a criação de associações técnico-científicas;

- organizar plantas cadastrais, registro de embarcações e aeronaves, vistoriadores e corretoras;

- publicar revistas especializadas de seguros;

- coletar e divulgar dados estatísticos.

Deve-se observar, primeiramente, que o IRB só opera com seguradoras e não possui qualquer vínculo com o Proagro. 
O IRB possui dois tipos de operações de resseguros: a básica e a de catástrofes. O resseguro básico possui duas derivações técnicas: resseguro de quotas $^{17}$ e resseguro de excedente de responsabilidade ${ }^{18}$.

Até 1993, o IRB assumia uma responsabilidade de $80 \%$ sobre as operações de seguro rural e as companhias de seguros, $20 \%$, ou seja, se uma seguradora assinasse apólices de vários seguros agrícolas no valor agregado de $\mathrm{R} \$$ $10.000 .000,00$ de importância segurada e os prêmios arrecadados alcançassem $R \$$ 1.000.000,00, a seguradora repassaria $R \$ 800.000,00$ em prêmios ao Instituto, que,

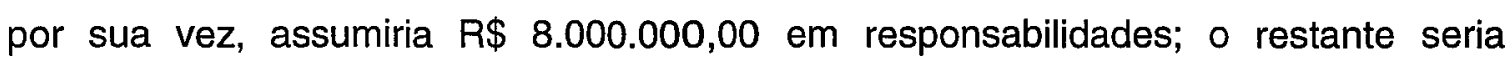
assumido pela seguradora. Este é o resseguro de quotas.

Entre 1993 e 1994, as responsabilidades alteraram-se, quando o IRB passou a assumir uma responsabilidade de $50 \%$ e as companhias de seguros, $50 \%$, ou seja, para uma importância segurada de $R \$ 10.000 .000,00$ e prêmios arrecadados no valor de $R \$ 1.000 .000,00$, a seguradora assumiria $R \$ 5.000 .000,00$ em responsabilidades, ficando com $\mathrm{R} \$ 500.000,00$ em prêmios, o restante seria assumido pelo IRB. Atualmente, o IRB assume uma responsabilidade de $20 \%$ e as companhias de seguros, $80 \%{ }^{19}$.

\footnotetext{
${ }^{17}$ No resseguro de quota (quota share), há cessão ao ressegurador de uma porcentagem da carteira global de determinado risco; a recuperação dos prejuízos é feita na mesma proporção. ${ }^{18} \mathrm{O}$ resseguro de excedente de responsabilidade (excess of liability) corresponde ao tipo de resseguro mais generalizado; a cessão ao ressegurador corresponde à soma que ultrapassa a retenção.

19 Essa mudança de responsabilidades provavelmente contribuiu para a desativação das carteiras de seguros rurais da maior parte das companhias brasileiras, exceto a Cosesp, que permaneceu em operação. Tem-se notícia de poucas companhias privadas atuando no seguro de pomares de maçã no RS.
} 
Até 1993, a responsabilidade do IRB era de $80 \%$ e das seguradoras, de $20 \%$. Mas, desses $80 \%$, o IRB pagava à seguradora $25 \%$ a título de comissão de resseguro ${ }^{20}$, ou seja, $20 \%$ do prêmio total. Desse modo, a seguradora responsabilizava-se por $20 \%$ da importância segurada e embolsava $40 \%$ do prêmio. Ou seja, uma importância segurada de $\mathrm{R} \$ 10.000 .000,00 \mathrm{com}$ prêmio de $10 \%$, $\mathrm{R} \$$ 1.000.000,00, a seguradora repassava ao IRB $80 \%$ do prêmio, porém cobrava $25 \%$ a

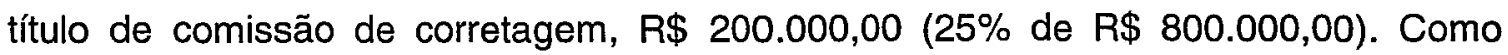
resultado o IRB se responsabilizava por $R \$ 8.000 .000,00$ de importância segurada e arrecadava $R \$ 600.000,00$ em prêmios e a seguradora se responsabilizava por $R \$$ 2.000.000,00 e arrecadava $R \$ 400.000,00$.

Após 1994, inverteram-se as taxas. O IRB assumiu a responsabilidade de $20 \%$ e a seguradora, $80 \%$. Para 1998, a Cosesp estaria reivindicando uma responsabilidade de $30 \%$ com o IRB assumindo $70 \%$.

Entretanto, para cada ramo de seguro é estabelecido um limite técnico de operação. Suponha-se que o limite técnico do ramo agrícola para aquela seguradora do exemplo seja $R \$ 600.000,00$ por contrato; portanto ela não poderá segurar os $R \$$ $800.000,00$ correspondentes aos $80 \%$ que the cabem. Nesse caso, existe um resseguro chamado de excedente de responsabilidade, do qual a seguradora deverá ceder ao IRB os R $\$ 200.000,00$ acima de seu limite. No final das contas, a seguradora do exemplo assumirá a responsabilidade sobre $R \$ 600.000,00$ e o IRB, sobre $R \$$ $400.000,00$.

O limite técnico é estabelecido pela Superintendência de Seguros Privados (Susep), levando em consideração o ramo de atuação e principalmente a solidez de cada seguradora, seus ativos etc. A Tabela 2 apresenta os limites técnicos dos primeiros semestres de 1995 e 1996 para as seguradoras brasileiras autorizadas a operar na carteira de seguros rurais.

${ }^{20}$ Todas as transações que envolvem prêmios são comissionadas, até mesmo o repasse do prêmio à resseguradora, que paga à seguradora uma comissão por isso (ver nota de rodapé no 9, pag. 25). 
Tabela 2. Limites Técnicos das Companhias de Seguros, 1995 e $1996^{21}$

\begin{tabular}{ccc}
\hline Seguradoras & $1995(\mathrm{em} \mathrm{mil} \mathrm{R} \$)$ & $1996(\mathrm{em} \mathrm{mil} \mathrm{R} \$)$ \\
\hline Bradesco & 594,0 & $1.107,7$ \\
Prudential (grupo Bradesco) & 19,7 & 141,2 \\
Bamerindus & 293,5 & 516,4 \\
Paraná (grupo Bamerindus) & 26,0 & 27,6 \\
Itaú & 480,0 & 808,4 \\
AGF - Brasil & 216,0 & 389,7 \\
Cosesp & 131,0 & 227,1 \\
Sul América & 0 & 123,0 \\
Unibanco & 91,0 & 224,1 \\
Bemge & 82,0 & 125,9 \\
Minas - Brasil & 38,0 & 56,8 \\
Sasse & 36,0 & 61,5 \\
Paulista & 32,0 & 50,5 \\
Hannover & 13,4 & 22,7 \\
Noroeste & 15,0 & 29,2 \\
Multiplic & 10,6 & 0 \\
\hline
\end{tabular}

Fonte: IRB (1996)

$\mathrm{Na}$ ocorrência de catástrofes relacionadas ao setor rural e na eventualidade de déficits operacionais relacionados aos resultados das seguradoras e do IRB, é mantido o Fundo de Estabilidade do Seguro Rural (seção 4.1), que pode ser acionado segundo critério estabelecido pelo IRB.

Se uma seca ou qualquer outro evento da natureza atinge vários segurados (mais de um) e a indenização ultrapassa o limite de $\mathrm{R} \$ 470.000,00$, é caracterizada a catástrofe, sendo que o valor indenizado acima do limite técnico de cada seguradora ou do IRB é imediatamente recuperado com recursos provenientes do FESR.

No caso do déficit operacional, a cada ano (todo mês de junho), as seguradoras e o IRB apresentam um balancete relacionando os resultados dos seguros agropecuários, penhor rural ${ }^{22}$ e seguro florestal. $O$ balancete possui receitas referentes a prêmios, comissões de resseguro (ver nota de rodapé $n^{\circ}{ }^{20}$ ) e sinistros

\footnotetext{
${ }^{21}$ (INSTITUTO DE RESSEGUROS DO BRASIL RJ) Limites técnicos no ramo de seguro rural:1995 e 1996.

${ }^{22} \mathrm{O}$ penhor rural é o seguro de bens (casas, tratores, benfeitorias etc.) dados em garantia a operações de financiamento de investimento, custeio etc. É a modalidade de seguro mais rentável para a seguradora, devido a seu baixo risco, sendo, em geral, a única modalidade responsável pelos depósitos no FESR.
} 
recuperados pelo FESR, e despesas relacionadas a pagamento de sinistros, comissões de corretagem, prêmios de resseguros cedidos e custos administrativos. Se o balancete apresentar déficit, o FESR transfere integralmente o valor à seguradora; entretanto, se houver superávit, $50 \%$ desse valor será depositado no fundo.

De acordo com informações não-oficiais, em junho de 1997, o IRB depositou no FESR por volta de R $\$ 5.000 .000,00$ e a Brasilseg, seguradora do Banco do Brasil, alimentou o fundo com $R \$ 4.000 .000,00$.

No Brasil, o setor de resseguro, através do Instituto de Resseguros Brasil (IRB), foi monopólio do governo desde sua criação em 1939 até 19 de junho de 1996, quando o Senado aprovou, em segundo turno, a emenda constitucional do deputado Cunha Bueno, referente à quebra do monopólio. Mas ainda faltam a elaboração e a votação, pelo Congresso, da lei complementar que regulamenta o artigo 192 da Constituição, que trata sobre o sistema financeiro nacional.

Em agosto de 1997 uma equipe designada pelo então Ministro da Fazenda Pedro Malan concluiu que o IRB necessitava de uma injeção de US\$ 250 milhões, causado por problemas gerenciais identificados no relatório. Após sanar as dificuldades financeiras o IRB deveria abrir seu capital.

De acordo com informações de agentes envolvidos no mercado de seguros, o governo divulgou o edital de qualificação de empresas que deverão prestar serviços referentes ao desenvolvimento do modelo de privatização que o Instituto adotará. Possivelmente no mês de julho de 1998 a empresa deverá ser escolhida para iniciar os trabalhos.

\subsubsection{Propostas para o Futuro}

Primeiramente, há necessidade de recapitular resumidamente as iniciativas e os resultados recentes que estão sendo apresentados pela Cosesp e Proagro: 
- Cosesp: Sinistralidade positiva pelo terceiro ano consecutivo; retomada ascendente do número de contratações de seguros; expansão da seguradora para o Estado do Paraná e, futuramente, para o Rio Grande do Sul.

- Proagro: Pagamento das dívidas atrasadas; aplicação do zoneamento agrícola em nível nacional; diminuição dos prêmios.

Como propostas para o futuro, pode-se citar três iniciativas que vêm em um momento em que a quebra do monopólio estatal das operações de resseguros gera um crescente interesse de companhias de seguros e resseguros internacionais pelo mercado nacional.

A Constituição Federal do Brasil de 1988, em seu Capítulo IV, Do Sistema Financeiro Nacional, no Artigo 192, entre outras providências, autorizou o funcionamento dos estabelecimentos de seguros, do órgão oficial fiscalizador e do órgão oficial ressegurador; autorizou também a criação de um fundo ou seguro, com objetivo de proteger a economia popular, vedada a participação de recursos da União. A regulamentação desse artigo, porém, ocorrerá por intermédio de lei complementar.

(a) Com o intuito de regulamentar os seguros agrícolas no Brasil, o senador Edson Lobão apresentou o Projeto de Lei do Senado $n^{\circ} 295^{23}$, de 1995, cujo relator é o senador Bello Parga ${ }^{24}$. O Projeto de Lei ainda permanece em tramitação, possuindo as seguintes providências:

- Institui o Sistema Nacional de Apoio ao Seguro Privado, com participação dos governos federal, estaduais, municipais, sociedades por ações, cooperativas, associações e sociedades de produtores rurais.

${ }^{23}$ LOBÃO, E. Projeto de Lei do Senado № 295. Brasília: Senado Federal, 1995. 6 p. (Em tramitação).

${ }^{24}$ PARGA, B. Parecer Brasília: Senado Federal, 1996. 6 p. 
- O seguro rural será regido por essa lei, complementarmente ao Decreto-Lei $\mathrm{n} \cong 73$, de novembro de 1966 (seção 4.1).

- As modalidades de seguro rural são: seguro agrícola; seguro pecuário; seguro de bens, equipamentos e produtos agropecuários; seguro de crédito para comercialização de produtos agropecuários; seguro temporário de vida dos produtores rurais.

- Os objetos da cobertura do seguro rural são custeio de culturas; animais de utilização econômica, inclusive fetos e embriões; equipamentos e instalações; veículos utilitários etc.

- Os riscos cobertos são incêndio e raio; pragas e doenças; danos causados por tromba d'água; ventos fortes; ventos frios; granizo; chuva excessiva; seca e geada.

- O seguro rural será obrigatório nas operações de crédito rural de custeio e de investimento; facultativo nas lavouras conduzidas com recursos próprios do produtor.

- O seguro rural será regulamentado, coordenado e fiscalizado por uma Comissão Federal Permanente composta por representantes do governo federal, das cooperativas, das associações de produtores agrícolas e das companhias seguradoras, sem prejuízo das determinações legais que regem o seguro privado.

- O seguro de penhor rural, o mais rentável dos seguros, só poderá ser operado por seguradoras que atuam com seguro rural, como forma de incentivo para as companhias.

- O Fundo de Estabilidade do Seguro Rural, criado pelo Decreto-Lei no 73 (1966), será constituído: (a) dos excedentes do máximo admissível tecnicamente como lucro nas operações de seguros de crédito rural, seus resseguros e suas retrocessões, segundo limites fixados pelo órgão fiscalizador; (b) da aplicação das reservas técnicas 
das sociedades seguradoras, conforme diretrizes do Conselho Monetário Nacional; (c) das comissões de corretagem de seguros nas licitações realizadas por órgãos públicos.

- Na ocorrência de sinistros generalizados, os recursos do fundo serão rateados entre os segurados, até o limite de $80 \%$ das importâncias seguradas.

- O Ministério da Agricultura, do Abastecimento e Reforma Agrária convocará comissão especial composta por representantes seus, do IRB, SUSEP, Banco do Brasil e de seguradoras, com o objetivo de regulamentá-la no prazo de 120 dias após a publicação desta lei.

(b) No âmbito da Câmara dos Deputados, foi apresentado o Projeto de Lei no 560 , de 1995, de autoria do deputado Valdir Colatto, cujo relator é o deputado Romel Anízio Jorge ${ }^{25}$. Segundo o relatório de junho de 1996, tem-se:

- Cria o Sistema Nacional de Seguro Rural, cujo objetivo é oferecer ampla cobertura, além da oferecida pelo Proagro;

- Torna o seguro facultativo;

- Permite a participação tanto empresas privadas como públicas;

- Cobre o capital físico e o capital circulante;

- Dá liberdade aos interessados em determinar as características da apólice (prêmios, coberturas, franquias etc.);

- Será auto-sustentável, com exceção dos casos catastróficos;

- Faculta resseguro, co-seguro e retrocessão;

- Cria a figura do corretor de seguro rural, cujas funções incluem assistência ao segurado nas relações com a seguradora;

${ }^{25}$ JORGE, R.A. Relatório do Projeto de Lei no 560. Brasília: Câmara dos Deputados, 1995, 4p. (em tramitação). 
- Cria um sistema local de arbitragem e resolução de conflitos;

- Institui um sistema especial de tratamento da questão dos sinistros catastróficos.

Este projeto reuniu os Projetos de Lei no 820/95 e no 1.140/95 de autorias dos deputados Adão Pretto e Ezídio Pinheiro, respectivamente. O Projeto de Lei no 820/95, diferencia-se nos seguintes aspectos:

- Seria provido por empresa estatal de economia mista;

- Seria controlado por um Conselho Administrativo organizado no âmbito federal e por conselhos municipais;

- Seria sustentado por um fundo constituído por prêmios arrecadados; dotações do Orçamento da União; por recursos correspondentes a $10 \%$ sobre os prêmios pagos sobre os seguros de bens, direitos, créditos e serviços prestados pelos órgãos da administração pública;

- regulamenta montantes e condições das indenizações.

O Projeto de Lei $n^{0} 1.140 / 95$ procurou principalmente transformar o Proagro exclusivamente em um programa de cobertura a pequenos produtores, assentados da reforma agrária e beneficiários do Pronaf.

Esses Projetos de Lei podem constituir-se como propostas para o futuro, porque definem regras e responsabilidades para o aperfeiçoamento do seguro rural no Brasil, porém permanecem parados nas duas casas. Com a proximidade do término do atual ciclo legislativo (novembro de 1998), os projetos correm o risco de serem arquivados, caso deputados e senadores responsáveis pelo mesmo não se reelejam.

(c) A terceira iniciativa partiu do Presidente da República Fernando Henrique Cardoso propondo a criação de um grande fórum para discutir problemas e soluções para o agribusiness. Em setembro de 1996, foi criado o Fórum Nacional da Agricultura (FNA), reunindo as mais expressivas lideranças, públicas e privadas, do agribusiness 
brasileiro, com o objetivo principal de criar estratégias e políticas futuras para o país, dentro do ambiente da competição global.

Foram criados 34 grupos temáticos, entre eles o de seguros rurais, presidido pelo Sr. Ágide Meneguette, presidente da Federação da Agricultura do Estado do Paraná (Faep). De acordo com os resultados dos estudos do grupo apresentados por MENEGUETTE (1997), o setor rural deve apoiar a lei que institui o Sistema de Apoio ao Seguro Rural, apresentada sob o título Projeto de Lei do Senado no 295 (complementar) de autoria do senador Edson Lobão. 
5 SEGURO RURAL NOS EUA 


\section{SEGURO RURAL NOS EUA ${ }^{26}$}

Desde 1985, várias mudanças vêm sendo implementadas na política agrícola norte-americana, com a finalidade de reduzir a atuação governamental nos mercados agropecuários. Com relação aos seguros rurais, a principal ação foi a aprovação da reforma do sistema federal de seguros, Federal Crop Insurance Reform Act of 1994, cuja alteração mais importante relaciona-se à eliminação do pagamento, aprovada automaticamente pelo Congresso, de grandes perdas ou catástrofes. Esse ato legislativo estimulou e favoreceu o crescimento de programas antigos e novos de seguros rurais.

Em 1996, foi aprovada a Federal Agricuture Improvement and Reform Act 1996 - Fair Act, dando um importante passo para a substituição paulatina do papel do Estado por instrumentos de mercado nos sete anos seguintes (YOUNG \& WESTCOTT, 1996).

O conjunto de medidas, por elevar o risco dos empreendimentos, ampliou de maneira significativa a atuação da Risk Manegement Agency (RMA), criada em $1994 \mathrm{e}$ cujo objetivo é fortalecer, ampliar e apresentar novas alternativas de cobertura.

Ultimamente, as mudanças nos seguros têm sido muito velozes, com diversos tipos de proteção sendo propostos. Aparentemente, o governo dos EUA está atravessando momentos de muita dúvida, uma vez que necessita diminuir as despesas com subsídios, mas tem dificuldade em criar alternativas privadas auto-sustentáveis. Talvez os riscos das atividades agropecuárias possuam, ainda hoje, expressivos fatores imponderáveis.

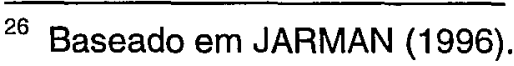


O órgão federativo máximo do seguro rural nos EUA é o Federal Crop Insurance Corporation (FCIC), que funciona como uma corporação governamental autônoma ligada ao United States Department of Agriculture (USDA), sendo seu superintendente um dos assessores do Secretário da Agricultura (RAY, 1981). O FCIC possui várias funções, tais como estabelecer prêmios, produzir conhecimento atuarial para cada cultura, calcular o preço máximo a ser pago por cada cultura no caso de indenização, organizar regras administrativas, ressegurar operações de companhias privadas etc. A administração dos programas de seguros rurais é responsabilidade de outro órgão ligado ao USDA, a Consolidated Farm Service Agency (CFSA).

Todas as operações realizadas pelas companhias seguradoras são resseguradas pelo FCIC segundo o Acordo-Padrão de Resseguro (Standard Reinsurance Agreement), através de três fundos que se diferenciam entre si de acordo com as responsabilidades de recolhimento de prêmios $e$ indenizações entre companhias e fundos (AZEVEDO, 1997 e COELHO, 1997).

No Fundo de Risco Assinalado a companhia repassa ao fundo até $80 \%$ das taxas líqüidas de prêmios arrecadados, em troca da responsabilidade de assumir até $80 \%$ do risco; no Fundo de Desenvolvimento, a responsabilidade assumida pela Companhia é, no mínimo, 35\%, contra $65 \%$ assumidas pelo mesmo; no Fundo Comercial, a companhia assume, no mínimo, $50 \%$ do valor do prêmio. Esses valores são compartilhados dentro do critério da proporcionalidade de responsabilidades.

O risco compartilhado entre companhias e resseguradoras não-proporcionais são estabelecidos de acordo com uma análise dos resultados (após ser aplicado o critério da proporcionalidade), no qual o fundo paga quantidades crescentes conforme a elevação das perdas.

Nos EUA, existem principalmente dois tipos de seguros rurais envolvendo seis modalidades de coberturas, que podem ser observadas na Figura 10. 


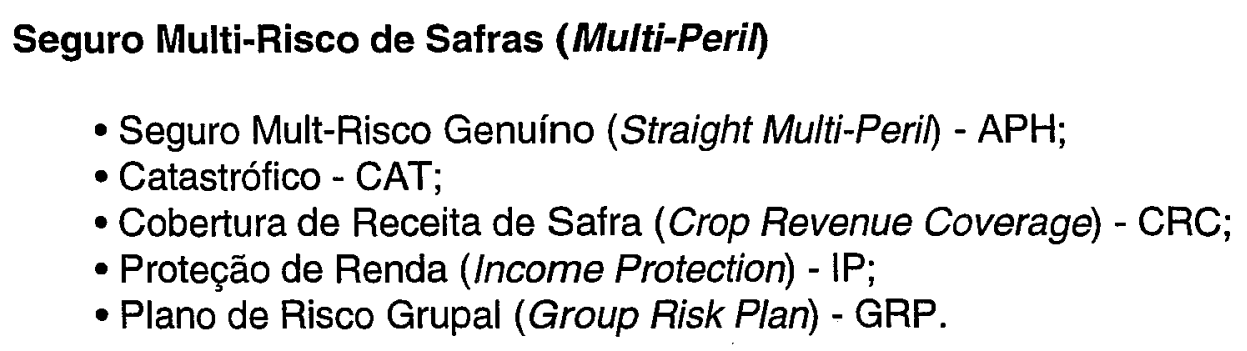

\section{Granizo (Hail)}

Fonte: JARMAN (1996)

Figura 10. Classificação dos Principais Programas de Seguros Agrícolas NorteAmericanos.

\subsection{Seguro Multi-Risco de Safras (Multi-Peril)}

Possui este nome porque cobre a maioria das causas de perdas naturais, tais como seca, excesso de chuvas, geada, granizo, vento, doenças, enchente, pragas e outras causas de animais selvagens.

São subsidiados pelo FCIC e operacionalizados pelas companhias de seguros privadas. Fazem parte de uma combinação entre fundos de companhias privadas e fundos federais, sendo que os últimos subvencionam $30 \%$ do custo do prêmio e garantem o pagamento de perdas catastróficas. A administração é feita por companhias privadas cuja venda do seguro e manutenção dos registros estão baseados em leis estabelecidas pelo Congresso dos EUA e em normas de administração estabelecidas pela $\mathrm{FCIC}$. Todas as companhias possuem os mesmos custos de seguros, visto que se utilizam das mesmas tabelas atuariais.

É impossível listar todas as culturas por municípios e estados que podem ser atendidas pelo Seguro Multi-Risco. Coberturas para milho e soja são oferecidas em todos os estados, mas culturas de caráter regional como tabaco, algodão e amendoim 
são oferecidas nos estados produtores tradicionais. Parcialmente, podem-se listar algumas culturas cobertas como cevada, milho, sorgo, soja, tabaco, semente de milho, aveia, centeio forrageiro, cana-de-açúcar, trigo, tomates de mesa e industriais, arroz, beterraba (para açúcar), algodão, milho de pipoca, milho doce, batata, cebola, pimenta, maçã, noz pecã, laranja, ameixa, grapes, figo, demais citrus, pêra, noz macadâmia, uva e pêssego.

\subsubsection{Seguro Multi-Risco Genuíno (Straight Multi-Peril - APH)}

É o mais abrangente de todos os tipos de seguros, garantindo proteção sobre certa quantidade de produto, com base na produtividade média histórica de cada produtor. A abreviação APH significa Actual Production History.

A produção histórica, de quatro a dez anos, de determinados propriedade e produtor, deverá estar especificada em registros enviados para a companhia de seguros anualmente. Caso não haja registro ou não se tenha produzido determinada mercadoria, será utilizada a produtividade estabelecida pelo Consolidated Farm Service Agency (CFSA) de acordo com as regras previamente estabelecidas.

Outra especificação refere-se às chamadas unidades (units). É o termo utilizado para definir em qual extensão de terras incidirá determinada faixa de prêmio. Cada propriedade é subdividida em talhões de acordo com as aptidões edafomorfológicas, geográficas e utilização (terras próprias, parceria agrícola ou arrendamento).

Deve-se escolher o nível de cobertura que se desejar $(50,55,60,65,70$ ou $75 \%$ ) e o nível de preço. O preço máximo a ser escolhido é anunciado pelo $\mathrm{FCIC}$ antes do início do plantio. Em 21/12/95, o FCIC anunciou os seguintes preços máximos: 
. milho, US\$2,65/bushel (bu) $)^{27}$ ou $R \$ 6,25 / \mathrm{sc}$;

. soja, US\$ $6,75 /$ bu ou $R \$ 14,88 / \mathrm{sc}$;

. sorgo, US\$2,50/bu;

. silagem de milho, US\$17,90/t.

O cálculo do prêmio e da indenização (no caso de perda) utilizará a produtividade histórica, o nível de cobertura e o preço escoihido. É importante citar que a produtividade média atingida pelo produtor, multiplicada pela porcentagem escolhida de cobertura, resulta na garantia de produtividade. Se a produtividade efetivamente colhida estiver aquém da garantida, devido à ocorrência de um sinistro, a diferença será multiplicada pelo preço escolhido e o valor será indenizado pelo programa.

A seguir, será apresentado um exemplo real. No município de Madison (EUA), um produtor de milho possui uma produtividade média de 150 bushels/acre $(\mathrm{ac})^{28}$ ou 156,9 sc/ha, sendo que seu custo operacional de produção são de US\$ 130,00 /ac. O arrendamento da terra custa US\$100,00/ac e se quer lucrar US\$ $30,00 / a c$. O total são de US $\$ 260,00 / a c$. O preço máximo estabelecido pelo FCIC em 1996 para o milho foram US $\$ 2,50 /$ bu. Ou seja:

. produtividade média: 150 bu/ac;

. nível de cobertura: $75 \%$;

. nível de garantia: 112,5 bu/ac;

. preço escolhido (máximo): US\$2,50/bu.

O valor de cobertura é US $\$ 281,25 / a c$, acima dos US $\$ 260,00 /$ ac desejados inicialmente. Caso haja perda e a produtividade seja menor que $112,5 \mathrm{bu} / \mathrm{ac}$, a seguradora indenizará a diferença. Neste exemplo, o valor do prêmio foram US\$ $8,00 / a c$, ou seja $2,84 \%$ do valor segurado.

Caso houvesse ocorrência de algum sinistro que diminuísse a produtividade para $100 \mathrm{bu} / \mathrm{ac}$, qual deveria ser a indenização paga?

\footnotetext{
${ }^{27} \mathrm{O}$ bushel representa uma medida de volume, sendo que um bushel de milho corresponde a $25,401 \mathrm{~kg}$ e um bushel de soja, a $27,216 \mathrm{~kg}$.

${ }^{28} \mathrm{O}$ acre (ac) é uma medida de superfície que corresponde a $4.047 \mathrm{~m}^{2}$ ou 0,4047 ha.
} 
O valor indenizado pode ser obtido através da fórmula (1):

$$
[(\mathbf{p m} \text { bu } / \mathrm{ac} \times \mathrm{nc})-\text { pa bu } / \mathrm{ac}] \times \text { US\$ pe } / \mathrm{bu}=\text { US } \$ \text { valor indenizado } / \mathrm{ac}
$$

onde:

pm = produtividade média (histórica);

nc $=$ nível de cobertura (de 50 até $75 \%$ ou 0,5 até 0,75 );

pa $=$ produtividade alcançada;

pe $=$ preço escolhido pelo $\mathrm{FCIC}$.

Aplicando os dados à fórmula (1), chega-se ao seguinte resultado:

$[(150 \mathrm{bu} / \mathrm{ac} \times 0,75)-100 \mathrm{bu} / \mathrm{ac}] \times \mathrm{US} \$ 2,5 / \mathrm{bu}=\mathrm{US} \$ 31,25 / \mathrm{bu}$

Com relação ao prêmio, os fatores que influenciam o valor cobrado são produtividade média (por unidade), seleção do nivel de cobertura, seleção do preço, tabelas de taxas atuariais e tabela de descontos de prêmios. Pode-se exemplificar através de outra operação: suponha-se que um produtor de trigo do município de Madison, no Estado de Indiana, possua uma produtividade média de 60 bu/ac e tenha optado por uma cobertura de $75 \%$ a um preço máximo de US\$3,55/bu.

As tabelas de taxas possuem vários limites de produtividade $e$, dentro de cada limite, existem seis níveis de cobertura, cada qual estabelecendo um multiplicador que é utilizado para encontrar a taxa de prêmio-base. Uma vez calculado o.prêmio-base, este é multiplicado pelo fator de descontos de prêmios, para obter o prêmio que o produtor deverá pagar. Assim:

. produtividade média: 60 bu/ac;

. nível de cobertura: $75 \%$;

. produtividade garantida: $45 \mathrm{bu} / \mathrm{ac}$;

. preço selecionado: US\$ 3,55/ac; 
. cobertura por acre: US $\$ 159,75$;

. fator da taxa atuarial: 0,05 ;

. prêmio-base: US\$7,98/ac;

. fator de desconto: 0,765 ;

. prêmio para o produtor: US\$ 6,11/ac;

. área total segurada: 50 acres;

. prêmio total: US\$305,50

. taxa administrativa: US\$10,00;

. total pago de prêmio: US\$ 315,50 na área total ou US\$ $6,31 / a c$ (3,95\% do valor segurado).

A diferença entre o prêmio-base e o prêmio para o produtor refere-se ao subsídio do governo federal. Se não incidisse o subsídio, o prêmio alcançaria $5,12 \%$.

Esse seguro também inclui frustração de plantio e replantio. Os eventos granizo e fogo poderão ser excluídos por opção do produtor. Se a cultura que se deseja segurar não estiver constando nas listas de culturas cobertas, poderão ser requeridos os cálculos atuariais ao $\mathrm{FCIC}$.

Por ser o seguro mais difundido nos EUA, será apresentada na Tabela 3, a evolução dos resultados apurados desde o início da década.

Tabela 3. Evolução do Seguro Multi-Risco Genuíno, de 1990 a 1996.

\begin{tabular}{lcccc}
\hline Ano & $\begin{array}{c}\text { Prejuízos } \\
\text { (bilhōes de US\$) }\end{array}$ & $\begin{array}{c}\text { Importância } \\
\text { Segurada Total } \\
\text { (bilhões de US\$) }\end{array}$ & $\begin{array}{c}\text { Prêmio } \\
\text { (bilhões de US\$) }\end{array}$ & $\begin{array}{c}\text { Sinistralidade } \\
(\%)\end{array}$ \\
\hline 1990 & 1,03 & 12,82 & 0,84 & 123 \\
1991 & 0,95 & 11,19 & 0,74 & 130 \\
1992 & 0,92 & 11,33 & 0,76 & 121 \\
$1993\left(^{*}\right)$ & 1,65 & 11,35 & 0,76 & 219 \\
1994 & 0,59 & 13,59 & 0,95 & 63 \\
1995 & 1,56 & 24,87 & 1,54 & 101 \\
1996 & 1,41 & 26,61 & 1,82 & 77 \\
\hline
\end{tabular}

$\left(^{*}\right)$ Ano das inundações no Mississippi, comprometendo seriamente a safra de grãos Fonte: AZEVEDO (1997) 
Pode-se observar na Tabela 3 que, após um ano de catástrofe (1993), cresceu 0 interesse por seguros, uma vez que vários produtores devem ter tido prejuízos em suas lavouras, fazendo crescer a importância segurada em $20 \%$. De 1994 para 1995, o crescimento foi ainda maior - 54,6\% - mas, nesse caso, como não houve catástrofes em 1994, pode ser atribuído às mudanças na legislação pela aprovação da Federal Crop Insurance Reform Act of 1994, que tornou os seguros agrícolas menos subsidiados.

Em 1996, emitiram-se 1.614.383 apólices de seguro com 372.899 indenizações, podendo ser considerado um ano de bons resultados. Pode-se observar que, nos três últimos anos os índices de sinistralidade apresentaram desempenho satisfatório, em comparação com a série de 1990 até 1993, quando não houve resultados positivos.

\subsubsection{Seguro Catastrófico (CAT)}

Criado pela lei de seguros de 1994 (Federal Crop Insurance Reform Act of 1994), apresenta uma forma mais barata de Seguro Multi-Risco, na qual o produtor paga apenas uma taxa administrativa de US $\$ 50,00$ por lavoura e segura $50 \%$ de sua produtividade histórica a preços de $60 \%$ do máximo estabelecido pelo FCIC. Nota-se que são utilizados a mesma produtividade e preços do seguro anterior, mas com porcentagens de cobertura diferentes. O teto em quantidade de seguro é de US\$ 200,00 por produtor no mesmo estado ou US $\$ 600,00$ no total.

Esse seguro torna-se obrigatório quando o produtor participa de programas governamentais subsidiados, como o Conservation Reserve Program (CRP) ${ }^{29}$.

\footnotetext{
29 Programa de Conservação de Reservas (Conservation Reserve Program - CRP) é uma provisão principal do Decreto de Segurança Alimentar de 1985 para reduzir a erosão e proteger a qualidade da água em 45 milhões de acres (18,2 milhões de hectares). O proprietário recebe um pagamento de aluguel anual, bem como $50 \%$ do custo de formação de uma cobertura vegetativa permanente. O novo Decreto de 1996 autoriza a manutenção do programa para 36,4 milhões de acres (YOUNG, 1996).
} 
Suponha-se que o mesmo produtor de milho do município de Madison (EUA), do exemplo anterior, tenha uma produtividade histórica de 150 bu/ac e o preço máximo estabelecido pelo $\mathrm{FCIC}$ tenham sido US $\$ 2,50 /$ bu. Devido à ocorrência de uma severa seca, obteve uma produtividade de $60 \mathrm{bu} / \mathrm{ac}$. Neste caso, a companhia de seguros pagará ao produtor US\$22,5/ac, de acordo com a fórmula (2):

$[(\mathbf{p m}$ bu $/ \mathrm{ac} \times \mathrm{nc})-\mathrm{pa}$ bu $/ \mathrm{ac}] \times$ US\$ pe $/$ bu $\times \mathrm{np}=$ US $\$$ valor indeniz. $/ \mathrm{ac}$

onde:

pm = produtividade média (histórica);

nc = nível de cobertura $(50 \%$ ou 0,5$)$;

$\mathbf{p a}=$ produtividade alcançada;

pe = preço escolhido pelo $\mathrm{FCIC}$;

np = nível de cobertura do preço $(60 \%$ ou 0,6$)$.

$[(150 \mathrm{bu} / \mathrm{ac} \times 0,5)-60 \mathrm{bu} / \mathrm{ac}] \times(\mathrm{US} \$ 2,5 / \mathrm{bu} \times 0,6)=\mathrm{US} \$ 22,5 / \mathrm{ac}$

\subsubsection{Cobertura de Receita da Safra (Crop Revenue Coverage - CRC)}

É o terceiro programa do Seguro Multi-Risco. Foi desenvolvido pelo grupo Redland Insurance Company, cujo programa apresenta características inovadoras, que garantem a proteção contra uma perda de receita resultante de oscilações de preços e/ou produtividade, ou seja, cobrindo a queda de produtividade na safra e, além disso, protegendo o preço de venda.

Foi operacionalizado inicialmente com culturas de soja e milho no plantio de 1996 nos estados de lowa e Nebraska. O sucesso desse programa fez o USDA intensificá-lo para outras culturas e estados. Segundo a American Agrinsurance, empresa do grupo Redland e uma das operadoras autorizadas a comercializar o 
produto em 1996, o CRC deverá estar disponível para todo os EUA dentro de três anos.

Dependendo da cultura, os preços podem variar diariamente para determinado mês futuro, sendo as bolsas de futuros utilizadas para esse propósito. Deve-se entrar em contato com um agente de seguros para determinar a bolsa a ser utilizada e a localização da cultura.

Serão definidas a seguir alguns termos que ajudarão o perfeito entendimento do exemplo adiante:

. preço-base: são utilizados $95 \%$ da média das cotações futuras, sinalizadas por uma bolsa de futuros, com a finalidade de calcular o prêmio e estabelecer o nível de garantia mínima. Para os contratos de trigo nos EUA, na Chigago Board of Trade (CBOT), utilizaram-se $95 \%$ da média das cotações diárias negociadas em agosto de 1996, referentes ao vencimento de julho de 1997.

- preco de mercado: é utilizado para determinar a garantia da safra e o cálculo da receita da safra. Representa a média das cotações futuras do mês seguinte ao vencimento do contrato de seguro, tornando seu cálculo transparente. $\bigcirc$ preço de mercado está limitado a um intervalo de US\$ 2,00 de oscilação em relação ao preçobase.

- nível de cobertura: é selecionado pelo segurado entre $50,55,60,65,70$ ou $75 \%$.

- produtividade média (histórica): produtividade média igualmente utilizada para o seguro multi-risco (subseção 5.1.1) para calcular o nivel de garantia.

- garantia mínima: é o mínimo de garantia para o cálculo do prêmio. É calculada multiplicando-se $\circ$ preço-base pela produtividade média histórica e aplicando-se ao resultado o nivel de cobertura.

- garantia da safra: é a multiplicação do preço de mercado pela produtividade média histórica, aplicando-se ao resultado o nível de cobertura.

- garantia final: é escolhido o valor mais alto entre a garantia mínima e a garantia da safra. 
- receita calculada: refere-se ao cálculo da receita obtida, multiplicando-se a produção obtida e pelo preço de mercado.

A indenização é devida se o valor de garantia final for superior ao da receita calculada. Nesse caso, a indenização será a diferença entre a garantia final e a receita calculada, denominada no exemplo abaixo como valor de cobertura ou perda por hectare.

Será apresentado a seguir um exemplo com diversos níveis de preços para que se possa entender a sistemática do seguro. $O$ exemplo utilizará valores nacionais pelas maiores familiaridade e facilidade de análise.

Suponha-se que um produtor de soja possua uma produtividade média histórica de $33 \mathrm{sc} / \mathrm{ha}$. Ao contratar esse seguro, escolherá o nível de cobertura de $75 \%$ e a bolsa que irá determinar seus preços. Essa bolsa está indicando um preço futuro, para determinado mês, de $\mathrm{R} \$ 15,20$ /sc e serão simulados resultados de quatro níveis de preços de mercado para a época de colheita $(\mathrm{R} \$ 13,50 ; 15,00 ; 15,50 ; 16,00 / \mathrm{sc})$. Se houver sinistro e o produtor obtiver uma produtividade de $20 \mathrm{sc} / \mathrm{ha}$, qual será a indenização que deverá receber?

A Tabela 4 apresenta, o mínimo de garantia para a cobertura (linha 5). 0 mínimo de garantia é calculado multiplicando-se a produtividade média (linha 1) pelo preço-base (linha 2), aplicando-se ao resultado (linha 3) o percentual do nível de cobertura (linha 4).

Tabela 4. Mínimo de garantia

\begin{tabular}{cc}
\hline Produtividade média (sc/ha) & 33 \\
Preço base $(\mathrm{R} \$ / \mathrm{sc})$ & 15,20 \\
Receita bruta $(\mathrm{R} \$ / \mathrm{ha})$ & 501,60 \\
Nível de cobertura $(\%)$ & 75 \\
Mínimo de garantia (R\$/ha) & 376,20 \\
\hline
\end{tabular}

Fonte: JARMAN (1996), adaptada pela pesquisa 
A Tabela 5 fornece os valores da garantia da safra (linha 5), isto é, a multiplicação entre a produtividade média (linha 1) e os possíveis preços de mercado (linha 2); sobre os resultados (linha 3), aplicam-se a porcentagem do nível de cobertura (linha 4).

De posse dos valores do mínimo de garantia (Tabela 4, linha 5) e da garantia da safra (Tabela 5, linha 5), escolhe-se o maior valor entre os dois, que será a garantia final (linha 6 da Tabela 5), utilizada para calcular o valor da cobertura.

Tabela 5. Garantia da safra e garantia final

\begin{tabular}{ccccc}
\hline produtividade média (sc/ha) & 33 & 33 & 33 & 33 \\
preços de mercado (R\$/sc) & 13,50 & 15,00 & 15,50 & 16,00 \\
Receita bruta (R\$/ha) & 445,50 & 495,00 & 511,50 & 528,00 \\
Nível de cobertura (\%) & 75 & 75 & 75 & 75 \\
Garantia da safra (R\$/ha) & 334,13 & 371,25 & 383,63 & 396,00 \\
\hline Garantia final (R\$/ha) & 376,20 & 376,20 & 383,63 & 396,00 \\
\hline
\end{tabular}

Fonte: JARMAN (1996), adaptada pela pesquisa

Neste exemplo, a lavoura de soja foi atingida por um sinistro, diminuindo-se sua produtividade para $20 \mathrm{sc/ha}$. Após a colheita, o produtor deverá vender sua safra remanescente pelo preço de mercado e obterá uma receita de safra, indicada na Tabela 6 (linha 3), de acordo com o preço de mercado obtido.

Tabela 6. Receita da safra e valor da cobertura

\begin{tabular}{ccccc}
\hline produtividade atual (sc/ha) & 20 & 20 & 20 & 20 \\
preço de mercado (R\$/sc) & 13,50 & 15,00 & 15,50 & 16,00 \\
receita da safra (R\$/ha) & 270,00 & 300,00 & 310,00 & 320,00 \\
\hline valor da cobertura (perda & 106,20 & 76,20 & 73,63 & 76,00 \\
por hectare) (R\$/ha) & & & & \\
\hline
\end{tabular}

Fonte: JARMAN (1996), adaptada pela pesquisa

Finalmente, subtraem-se dos valores da garantia final (Tabela 5, linha 6) os valores da receita da safra (linha 3 da Tabela 6), resultando no valor da cobertura, (Tabela 6, linha 4). 
Deve-se lembrar que o preço pode apresentar uma variação de apenas U\$ 2,00 em relação ao preço base (estabelecido na contratação do seguro, antes do plantio), ou seja, no exemplo acima, poderia elevar-se até $\mathrm{R} \$ 17,20 / \mathrm{sc}$. Considera-se que a seguradora, para proteger-se do risco de uma elevação no preço do objeto do seguro, deve-se travar no mercado de opções (seção 6.3).

O CRC possui provisões para indenizar o atraso no plantio, replantio e frustração no plantio, com as mesmas regras do seguro multi-risco - APH. No caso da frustração de plantio, só se procede à indenização se não houver a possibilidade de plantio devido a um perigo de perda. Se a terra for deixada ociosa, o produtor receberá $50 \%$ do mínimo de garantia; se plantada outra lavoura, receberá $25 \%$ da garantia.

Não se pode utilizar esse seguro, CRC, conjuntamente com o Seguro MultiRisco, APH, e com o Plano de Risco Grupal (GRP).

O CRC é semelhante ao APH no que se refere às datas de cobertura e de pagamentos de prêmios. Os prêmios e as perdas são calculados sobre a mesma porção das unidades (units) em ambos os seguros.

As vantagens do CRC são:

- As coberturas são realizadas assegurando o nível de produção e o nível de preços. O custo da cobertura é menor que o de outras formas de proteção de preços, como o hedge por contratos a termo, futuros e opções;

- A proteção refere-se a uma quantidade de valor monetário por área e não a uma quantidade de produto por área;

- A indenização é feita de acordo com a produtividade de cada unidade e não pela média das produtividades em todas as unidades da propriedade, como estabelecem os seguros GRP, IP (detalhados adiante) e CAT. Se as produtividades em duas unidades de um mesmo produtor são 55 e 15 sacas de soja por hectare, esse 
seguro indenizará a unidade que produziu $15 \mathrm{sc} / \mathrm{ha}$. No caso dos outros seguros acima citados, caberá uma indenização de acordo com a média das duas unidades, 35 sc/ha.

As desvantagens são:

- O prêmio é mais caro que o do plano APH;

- Quando o preço de mercado estiver maior que o preço-base do CRC, o plano APH pode pagar uma cobertura maior. O CRC é mais vantajoso em anos de mercados normais, isto é, preços baixos na safra e altos na entressafra.

\subsubsection{Proteção de Receita (Income Protection - IP)}

É uma modalidade de seguro que se aproxima bastante do $\mathrm{CRC}$, possuindo apenas duas diferenças significativas. No CRC, para o cálculo da indenização, podese optar pelo valor mais alto entre os cálculos do mínimo de garantia e da garantia da safra, enquanto o IP, existe apenas o cálculo do mínimo de garantia. Também o cálculo da indenização será sobre a média apurada pela somatória de todas as unidades seguradas, o que não existe no CRC. Por exemplo: em uma fazenda inundada por um rio, apenas algumas áreas serão atingidas; quando somadas às áreas não atingidas e calculada a média, pode não haver indenização para receber.

A vantagem do IP sobre os anteriores é a facilidade burocrática em contratálo.

A seguir, será apresentado um exemplo do funcionamento do IP. Os valores serão colocados em notação nacional para facilitar o acompanhamento e a análise.

Suponha-se, igualmente ao exemplo anterior, que um produtor de soja possua uma produtividade média histórica de $33 \mathrm{sc} /$ ha. Ao contratar esse seguro, escolherá o nível de cobertura de $75 \%$ e é a bolsa que irá determinar seus preços. Essa bolsa está indicando um preço futuro, para determinado mês, de $\mathrm{R} \$ 15,20 / \mathrm{sc}$. Se 
houver sinistro e o produtor obtiver uma produtividade de $20 \mathrm{sc} / \mathrm{ha}$, qual será a indenização que deverá receber?

Primeiramente, efetua-se o cálculo do valor mínimo de garantia, apresentado na Tabela 7 (linha 5).

Tabela 7. Mínimo de garantia, receita da safra e valor da cobertura

\begin{tabular}{|c|c|c|c|c|}
\hline $\begin{array}{c}\text { produtividade média (sc/ha) } \\
\text { preço-base }(\mathrm{R} \$ / \mathrm{sc}) \\
\text { receita bruta }(\mathrm{R} \$ / \mathrm{ha}) \\
\text { nível de cobertura }(\%) \\
\text { mínimo de garantia (R\$/ha) }\end{array}$ & & & $\begin{array}{l}3 \\
20 \\
60 \\
5 \\
20\end{array}$ & \\
\hline $\begin{array}{l}\text { produtividade atual (sc/ha) } \\
\text { preço de mercado ( } \mathrm{R} \$ / \mathrm{sc}) \\
\text { receita da safra (R\$/ha) }\end{array}$ & $\begin{array}{c}20 \\
13,50 \\
270,00 \\
\end{array}$ & $\begin{array}{c}20 \\
15,00 \\
300,00 \\
\end{array}$ & $\begin{array}{c}20 \\
15,50 \\
310,00 \\
\end{array}$ & $\begin{array}{c}20 \\
16,00 \\
320,00 \\
\end{array}$ \\
\hline $\begin{array}{l}\text { valor da cobertura (perda } \\
\text { por hectare) }(R \$ / h a)\end{array}$ & 106,20 & 76,20 & 66,20 & 56,20 \\
\hline
\end{tabular}

Fonte: JARMAN (1996), adaptada pela pesquisa

Em seguida, calcula-se a receita da safra (linha 8), baseada na produtividade (linha 6) obtida após a ocorrência do sinistro e no preço de mercado (linha 7). A diferença entre o valor mínimo de garantia (linha 5) e a receita obtida pela safra aos preços de mercado (linha 8 ) resultará no valor da cobertura ou perda por hectare, linha 9 da Tabela 7.

A diferença entre $O \mathrm{CRC}$ e $\circ \mathrm{IP}$ é que o primeiro garante a cobertura da produtividade média histórica em relação ao maior valor entre o preço-base (determinado na assinatura do contrato) e o preço de mercado (determinado no vencimento do contrato), subtraído da produtividade apurada ao preço de mercado, e o segundo garante apenas a cobertura da produtividade média histórica ao preço-base subtraído da produtividade apurada ao preço de mercado.

É importante analisar os preços futuros antes de contratar determinado tipo de seguro, podendo ser mais vantajoso utilizar o Seguro Multi-Risco Genuíno. 


\subsubsection{Plano de Risco Grupal (Group Risk Plan - GRP)}

É uma modalidade de seguro muito diferente dos anteriores. Está disponível apenas para milho, soja e trigo em muitos estados e para forragem em alguns estados, cobrindo riscos naturais.

A diferença dos outros seguros é que a produção individual não entra no contexto, mas a média do município. Isto é, caso uma região tenha sido danificada por um sinistro e o restante do município tenha obtido ótimas produtividades nas demais regiões, a região atingida não receberá indenização alguma. A média é calculada pelo Serviço Nacional de Estatística.

O produtor escolhe uma porcentagem da média fixada para o município para aquele ano e seleciona 0 preço a ser pago para a mercadoria em eventual indenização. Caso o volume médio colhido no município esteja abaixo do que foi selecionado, caberá a indenização. A média de cada município é calculada preliminarmente todos os anos.

As vantagens sobre os demais seguros é que não há necessidade de manter relatórios sobre produtividades históricos das unidades.

Como desvantagens, têm-se:

. pode haver ocorrência de enchente ou granizo resultando em produtividade baixa em determinada região; mas, se a média total do município for maior que a porcentagem anteriormente selecionada, não será devida indenização;

. dependendo da cobertura escolhida, GRP e os demais apresentarão o mesmo patamar de custos;

. não inclui replantio e frustração de plantio.

A Tabela 8 apresenta as principais diferenças entre os cinco tipos de Seguros Multi-Risco: 
Tabela 8. Principais diferenças entre os cinco programas do Seguro de Risco Múltiplo

\begin{tabular}{|c|c|c|c|c|c|}
\hline & APH & CAT & CRC & IP & GRP \\
\hline Dividido em unidades (units) & $\operatorname{sim}$ & não & $\operatorname{sim}$ & não & não \\
\hline Protege a produtividade & $\operatorname{sim}$ & $\operatorname{sim}$ & $\operatorname{sim}$ & $\operatorname{sim}$ & ${ }^{*} 1$ \\
\hline Protege o preço & não & não & $\operatorname{sim}$ & $\operatorname{sim}$ & não \\
\hline Indeniza frustração de plantio & $\operatorname{sim}$ & não & $\operatorname{sim}$ & $\operatorname{sim}$ & não \\
\hline Indeniza replantio & $\operatorname{sim}$ & não & $\operatorname{sim}$ & $\operatorname{sim}$ & não \\
\hline Indeniza plantio tardio & $\operatorname{sim}$ & $\operatorname{sim}$ & $\operatorname{sim}$ & sim & $\operatorname{sim}$ \\
\hline Indeniza qualidade da semente & $\operatorname{sim}$ & $\operatorname{sim}$ & $\operatorname{sim}$ & $\operatorname{sim}$ & não \\
\hline Seleciona nível de cobertura & $\operatorname{sim}$ & não & $\operatorname{sim}$ & $\operatorname{sim}$ & $\operatorname{sim}$ \\
\hline Seleciona nível de preço & $\operatorname{sim}$ & não & *2 & *2 & $\operatorname{sim}$ \\
\hline
\end{tabular}

Fonte: JARMAN (1996)

*1 - sim, baseado na produtividade média do município e não na produtividade média individual;

*2 - preço variável, dependendo das flutuações do mercado.

Nota-se que essas cinco modalidades de seguro, amparadas pela política agrícola de subsídios norte-americana, são uma tentativa de abranger as situações mais específicas e adversas relacionadas às atividades rurais, com o objetivo de proteger a renda do produtor.

Exceto o programa GRP, todos necessitam de fiscalizações periódicas e controles rigorosos, aumentando-se o custo de manutenção dos programas e, conseqüentemente, os subsídios governamentais. $O$ controle e a fiscalização do contrato de seguro são uns dos principais problemas enfrentados por companhias seguradoras, em todo o mundo.

Pode-se observar que os programas CRC e IP contratam e liquidam suas apólices tomando como base, além da produtividade histórica, as cotações futuras de uma das bolsas de futuros do país. As bolsas norte-americanas, por apresentarem alto grau de desenvolvimento, agregam diversas forças mundiais representantes de setores ofertantes e demandantes, resultando em um preço próximo da realidade e principalmente transparente, isto é, qualquer produtor poderá acompanhar a evolução das cotações pelos meios usuais de comunicação.

Deve-se salientar que 0 recente desenvolvimento de seguros rurais com garantia de receita pressupõe a utilização de cotações futuras negociadas em bolsas. 
Para tanto, exige-se uma liqüidez satisfatória, o que permitirá maior credibilidade às cotações futuras.

\subsection{Seguro contra Granizo - Companhias Privadas}

O seguro contra granizo já atua há 75 anos e não possui qualquer subsídio governamental. Engloba também cobertura contra incêndio, armazenagem e transportes.

Basicamente, o produtor seleciona o valor da indenização por unidade de área (US\$/ac). Se houver sinistro, a companhia avaliará a quantidade de perda e realizará o pagamento.

Muitos produtores procuram esse seguro devido ao elevado nível de perda causada pela ocorrência de granizo e incêndio, ao reduzido valor do prêmio e à sua facilidade. Como exemplo, por um seguro para a cultura do milho no município de Madison, paga-se uma taxa de US\$ 0,60 para cada US\$100,00 de indenização, ou seja, um prêmio de $0,6 \%$. 
6 MODELOS ALTERNATIVOS 


\section{MODELOS ALTERNATIVOS}

Este capítulo procura identificar alguns modelos privados alternativos aos seguros rurais tradicionais. Serão apresentados seguros em funcionamento, em desenvolvimento e em processo de estudos.

O desenvolvimento de modelos privados está condicionado principalmente ao fim do monopólio do mercado ressegurador brasileiro, uma vez que a abertura desse mercado poderá atrair empresas interessadas em atuar no Brasil.

\subsection{Seguros Mútuos}

Os seguros mútuos geralmente são operados por cooperativas ou por associações de produtores. As cooperativas agropecuárias podem constituir fundos de seguros mútuos entre seus cooperados para operar em seguros rurais, inclusive industriais e de acidentes de trabalho. No Brasil, existem poucas cooperativas trabalhando nesse segmento, apesar da carência de seguros rurais no país. Entre elas, serão abordados os modelos da Cooperativa Agropecuária Batavo Ltda. e da Cooperativa Agrária Mista Entre Rios Ltda. As associações não são organizações comerciais, mas se aproximam à filosofia cooperativista e segundo a pesquisa existe apenas uma associação de seguro mútuo, a Associação dos Fumicultores do Brasil Afubra. 


\subsubsection{Cooperativa Agropecuária Batavo Ltda.}

A Cooperativa Agropecuária Batavo, sediada no município de Carambeí, PR, criou um fundo para segurar as lavouras de milho e de soja de seus cooperados a partir de 1985. Assim, foi regulamentado o Fundo Mútuo Agrícola (FMA) ${ }^{30}$, cujo objetivo é indenizar o produtor dos custos aplicados nas lavouras de soja e de milho no caso de diminuição de receitas em conseqüência de perdas provocadas por seca, granizo, doença ou praga sem método difundido de combate, controle, profilaxia técnica e economicamente exeqüivel.

Os custos utilizados para efeito de indenização estão baseados no Custo Médio de Produção/Batavo, sendo calculados pelo Departamento de Assistência Técnica (DAT). Além disso, o DAT enquadra as lavouras; calcula e debita a taxa de participação; recebe a comunicação de perdas; efetua $\circ$ cálculo e 0 crédito da cobertura deferida; acompanha as lavouras etc.

Para ter o direito de participar do FMA, o produtor deverá utilizar boa tecnologia; programar o plantio e aceitar recomendações do DAT; entregar toda a produção e adquirir todos seus insumos na cooperativa; ter obtido uma produtividade média, nas duas últimas safras, acima de $2.000 \mathrm{~kg} / \mathrm{ha}$ para soja e de $4.500 \mathrm{~kg} / \mathrm{ha}$ para milho.

O cooperado deve comunicar ao DAT em até 72 horas, a ocorrência de qualquer evento que possa motivar diminuição de receitas. A vistoria será realizada pelo DAT e, em caso de dúvida na comprovação de perdas, convocará a Comissão de Avaliação, composta por seis associados agricultores.

30 Baseado no regulamento de Fundo Mútuo Agrícola de 26 de agosto de 1992; relatórios fornecidos pela cooperativa e conversas telefônicas. 
Até 1994, era cobrada taxa de participação (prêmio) a ser paga pelo produtor, cujos valores eram $7 \%$ para soja e $10 \%$ para milho sobre o Custo Médio de Produção Batavo. A taxa de participação era depositada na cooperativa somente após a colheita, sendo que, se não houvesse sinistro algum, não haveria recolhimento.

O cálculo da cobertura era a diferença entre o custo da lavoura e a receita obtida com a venda da produção remanescente. Se o montante a indenizar fosse superior ao valor da taxa de participação, era feito um rateio proporcional dos valores a indenizar, caso contrário, o saldo remanescente seria restituído proporcionalmente a cada participante.

No ano agrícola 92/93, houve uma única propriedade sinistrada com a ocorrência de chuva de granizo, atingindo parcialmente seus 40 hectares plantados. Até a safra 96/97, não houve ocorrência alguma. De acordo com a experiência dos doze últimos anos, a taxa de perda mais alta chegou a $2 \%$ do custo de produção.

Atualmente, os cooperados aprimoraram o FMA, não sendo mais necessária a cobrança da taxa de participação. As indenizações somadas são rateadas entre os cooperados após a colheita e a responsabilidade de cada cooperado no risco total está limitado a, no máximo, $7 \%$ de seu custo de produção.

$\mathrm{Na}$ última safra, 96/97, de 36.188 hectares inscritos com soja, 541 sofreram perdas causadas por granizo, em um valor total de $\mathrm{R} \$ 30.357,80$, cujo rateio entre os cooperados ficou em $R \$ 0,8389 /$ ha, o que correspondeu a aproximadamente $0,2 \%$ do custo médio de produção. A Tabela 9 demonstra os cálculos realizados para se chegar ao resultado do rateio. 
Tabela 9. Cálculos das Indenizações de Soja, safra 96/97

\begin{tabular}{crrrrr}
\hline & \multicolumn{5}{c}{ Produtores } \\
& \multicolumn{1}{c}{$\mathrm{A}$} & \multicolumn{1}{c}{$\mathrm{B}$} & $\mathrm{C}$ & \multicolumn{1}{c}{$\mathrm{D}$} & \multicolumn{1}{c}{$\mathrm{E}$} \\
\hline Área inscrita (ha) & 205 & 106 & 32 & 145 & 50 \\
Área Sinistrada (ha) & 73,22 & 88,92 & 32,00 & 45,70 & 42,07 \\
Custo de Prod. Médio/Batavo & 508,08 & 516,46 & 511,82 & 523,26 & 428,25 \\
(R\$/ha) & & & & & \\
Preço médio líqüido da soja (R\$/sc) & 16,08 & 16,08 & 16,08 & 16,08 & 16,08 \\
Produtividade segurada (kg/ha) & $1.864,50$ & $1.895,25$ & $1.878,23$ & $1.920,23$ & $1.571,57$ \\
Produtividade obtida (kg/ha) & $1.455,00$ & $1.816,00$ & $1.627,00$ & $2.104,00$ & 0 \\
Produtividade a indenizar (kg/ha) & 409,50 & 79,25 & 251,23 & - & $1.571,57$ \\
Valor da indenização (R\$) & $8.035,60$ & $1.888,57$ & $2.154,55$ & - & $17.719,07$ \\
\hline
\end{tabular}

Fonte: COOPERATIVA AGROPECUÁRIA BATAVO LTDA (1997)

Aos totais indenizados para cada cooperado, descritos na Tabela 9, acrescentam-se $\mathrm{R} \$ 560,00$ relacionados a outras despesas. Divide-se, então, o valor a ser indenizado, $R \$ 30.357,80$, pela área total inscrita, $36.188,01$ hectares, resultando em um valor de rateio de $R \$ 0,8389 / \mathrm{ha}$ ou $3,13 \mathrm{~kg}$ de soja $/ \mathrm{ha}$.

Pode-se observar, na mesma tabela, que, na lavoura do cooperado D, mesmo com a ocorrência da chuva de pedra, a produtividade obtida foi superior à produtividade segurada, não havendo nada a receber. Por outro lado, o cooperado $E$ teve sua lavoura dizimada, o que the deu o direito de receber a totalidade da produtividade segurada, correspondente ao custo de produção.

A Tabela 10 apresenta a participação dos cooperados de 92/93 a 96/97. Nota-se um nível de aproximadamente $67 \%$ de participação entre as áreas de milho e soja ao longo desses cinco anos. 
Tabela 10. Seguro agrícola da Cooperativa Agropecuária Batavo, 92/93 a 96/97

\begin{tabular}{ccccccccccc}
\hline & \multicolumn{2}{c}{$92 / 93$} & \multicolumn{2}{c}{$93 / 94$} & \multicolumn{2}{c}{$94 / 95$} & \multicolumn{2}{c}{$95 / 96$} & \multicolumn{2}{c}{$96 / 97$} \\
& soja & milho & soja & milho & soja & milho & soja & milho & soja & milho \\
\hline $\begin{array}{c}\text { ha } \\
\text { plantados }\end{array}$ & 37.393 & 16.329 & 42.865 & 17.168 & 45.429 & 17.185 & 41.687 & 18.982 & 48.487 & 19.302 \\
$\begin{array}{c}\text { ha } \\
\text { inscritos }\end{array}$ & 25.647 & 11.204 & 23.691 & 9.927 & 27.514 & 11.389 & 27.514 & 11.389 & 36.188 & 16.600 \\
partic. \% & 69 & 69 & 55 & 58 & 61 & 66 & 66 & 60 & 75 & 86 \\
\hline
\end{tabular}

Fonte: COOPERATIVA AGROPECUÁRIA BATAVO LTDA (1997)

6.1.2 Cooperativa Agrária Mista Entre Rios Ltda.

Em março de 1996, a Cooperativa Agrária, sediada em Entre Rios, PR, criou - Plano Privado de Cobertura Complementar de Prejuízos Causados por Granizo. O plano cobre somente perdas causadas por granizo.

O plano é administrado por um conselho composto por seis membros: chefe da Divisão de Assistência Técnica, chefe da Divisão de Crédito e Financiamento e quatro componentes do Comitê Agrícola. Sua função é enquadrar as lavouras, determinar a execução de perícia, estipular os limites de cobertura etc.

Para poder participar, o cooperado deve aplicar as recomendações técnicas dadas pelo agrônomo da cooperativa, cumprir as obrigações estatutárias, adquirir todos os insumos e vender a produção na cooperativa. A adesão ao plano é facultativa, sendo obrigatória apenas no caso de a Cooperativa Agrária participar com algum risco do empreendimento do cooperado, como aval, repasses etc.

O plano cobre as culturas de milho, soja, trigo, cevada e aveia. A indenização baseia-se no custo de produção, observando os insumos utilizados, sem nunca ultrapassar o orçamento calculado pela Divisão de Assistência Técnica.

Para o cálculo da indenização, utilizam-se os custos registrados, limitados ao valor equivalente ao orçamento de desembolso para cada cultura, deduzindo-se o 
valor da produção colhida na mesma área. O preço para base de cálculo é apurado no mercado do dia 31 de maio (para as culturas de verão) e no de 31 de janeiro (para as culturas de inverno). O valor de todas as indenizações somadas é dividido pelo número de hectares e, assim, determinado o valor do rateio.

Em seu primeiro ano de operação, 96/97, as indenizações para a cultura da soja alcançaram R\$16.763,52, para uma área segurada de 46.970,89 hectares, ou seja, $R \$ 0,3569 /$ ha.

\subsubsection{Associação dos Fumicultores do Brasil - Afubra ${ }^{31}$}

Possui um fundo mútuo que cobre seus associados contra a ocorrência de granizo desde 1957. A Afubra foi criada em 1955 com o objetivo de amparar o produtor de fumo na negociação de preços com a indústria, no desenvolvimento de pesquisas; no fornecimento de seguros rurais etc.

Baseado na mutualidade, o seguro fornecido pela associação cobre lavouras de fumo danificadas por granizo, incêndio nas estufas durante a cura do tabaco e auxílio funeral.

\subsection{Seguro Garantia ${ }^{32}$}

O agravamento da crise econômica que o país atravessou durante a década de 80 refletiu-se na política de crédito rural subsidiado, diminuindo consideravelmente o volume de recursos disponíveis ao produtor rural e gerando conseqüências danosas aos fornecedores de insumos e processadores de matéria-prima.

${ }^{31}$ Baseada em ASSOCIAÇÃO DOS FUMICULTORES DO BRASIL (1998).

${ }^{32}$ Os dados apresentados neste tópico correspondem a uma série de entrevistas e a um apanhado de correspondências e projetos fornecidos pela GERENSEG Administração e Gerenciamento de Seguros Ltda., através do Dr. Roberto G. Rocha Azevedo. 
A solução encontrada por alguns desses setores privados foi o financiamento de recursos ou insumos para o produtor rural, muitas vezes antes do plantio, em troca da obrigação de entrega da mercadoria financiada, por ocasião da colheita. Esses financiamentos foram realizados basicamente por exportadores de soja, que reuniam uma série de vantagens como:

- poder contar com recursos externos como adiantamentos de contratos de câmbio $(\mathrm{ACC})^{33}$;

- recursos com taxas de juros extremamente baixas comparadas ao custo do capital interno.

. as exportadoras do complexo soja poderiam proteger-se contra oscilações desfavoráveis de preços na Chicago Board of Trade (CBOT), através dos contratos futuros de soja, uma vez que, possuíam alta correlação entre preços internos e externos. Segundo SOUSA (1996), o estudo das oscilações de preços mensais internos e externos (Brasil e EUA) da soja grão, entre 1984 e 1995, apresentou um índice de correlação de 0,8 .

A associação desses fatores permitiu a criação das operações conhecidas como "venda antecipada" ou "soja verde" e "troca-troca ou escambo", nos anos de 1987/88, detalhadas na Figura 11. Essas operações foram amparadas por um contrato de compra e venda criado pela Associação Nacional dos Exportadores de Cereais (ANEC) e estavam fundamentadas no fornecimento de recursos externos, como o ACC.

${ }^{33} \mathrm{O}$ Adiantamento de Contrato de Câmbio (ACC) é um incentivo dado às exportações. É um adiantamento dado exclusivamente a exportadores que já tenham exportação contratada. $O$ banco, fornecedor do crédito, cobra a correção cambial mais uma taxa de juros, sendo que a garantia é o contrato de venda entre o exportador e o importador. A liqüidação faz-se única e exclusivamente através do embarque da mercadoria, quando o importador realiza o pagamento diretamente ao banco e liqüida o ACC. 


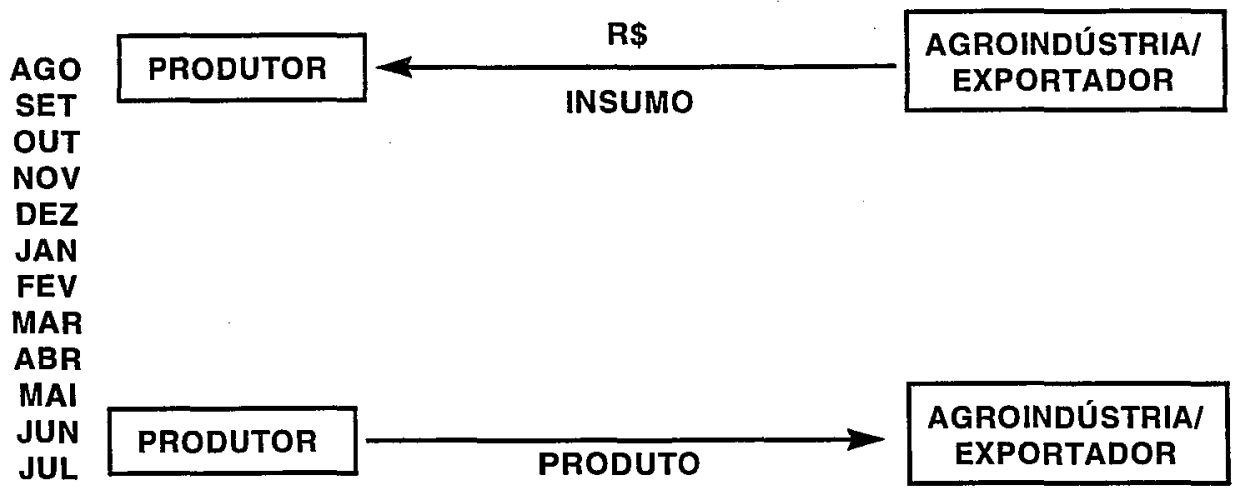

Fonte: CAFFAGNI (1995)

Figura 11. Fluxo operacional de venda antecipada ou "soja verde" e troca de insumo por produto ou "escambo"

Nos anos seguintes, o número de operações desse tipo cresceram, atingindo, em 1993, a cifra de US $\$ 1,3$ bilhão em volume de operações ou quase $50 \%$ da necessidade de financiamento do setor de produção de soja (SOUSA, 1996). Segundo AZEVEDO (1997), esses pré-financiamentos já não se restringem apenas a grãos, sendo também utilizados em cana-de-açúcar, cacau, cítricos, fumo, café e frutas em geral, estimando-se que os recursos totais anuais (1997) já alcancem algo em torno de US $\$ 10$ bilhões.

Este modelo de financiamento estava associado ao risco de não-entrega. Se a entrega da produção não fosse realizada, devido a frustrações de safras generalizadas no setor de produção, a empresa exportadora teria dificuldade em embarcar a mercadoria. Nesse caso, ou a empresa adquiriria produto no mercado para realizar a exportação, ou perderia seu cliente importador e ficaria inadimplente com o banco credor, uma vez que a importadora não liqüidaria o ACC. Essa possibilidade preocupava os agentes financeiros fornecedores de $A C C$, importadores e empresas de exportação.

Portanto, devido ao risco de ocorrência de eventos danosos incontroláveis à produção de soja, no final de 1989, iniciou-se um movimento dos agentes envolvidos para constituir um seguro garantia para estes tipos de operações. 
No início de 1991, iniciou-se a aproximação de uma exportadora que operava grandes volumes de soja no Brasil e de uma corretora de resseguros internacional para o desenvolvimento de um produto que atendesse às necessidades operacionais das empresas envolvidas. Como a atividade resseguradora era monopólio governamental, através do Instituto de Resseguros do Brasil (IRB), havia necessidade de obter aprovação e/ou apoio do referido instituto. A corretora de seguros brasileira que intermediava as negociações era a Rocha Azevedo Corretora de Seguros Ltda.

Nos dois anos seguintes, diversas alternativas foram estudadas, desde o seguro rural tradicional para o produtor até o seguro para cobrir apenas catástrofes naturais.

Em 1993, optou-se pela contratação de um seguro de riscos catastróficos, de forma agregada, cobrindo todos os contratos de adiantamento pela empresa a mais de 1.500 produtores de soja. Para tanto, a resseguradora internacional contratou os serviços de uma consultoria especializada em estudos de administração de riscos em agricultura, a inglesa ARM - AGRICULTURAL RISK MANAGEMENT LTD., para preparar um relatório final a ser apresentado ao Consórcio de Riscos Agrícolas do LLOYD'S (LARC) em Londres. O relatório previa um valor de risco inicial de US\$ 85,5 milhões e um máximo de US\$136,6 milhões ao final da safra, pelas projeções do preço da soja no mercado internacional para 01/06/94. A ARM calculou a perda máxima provável de $16,67 \%$ e estabeleceu a importância segurada em US\$23 milhões. A proposta de taxa de prêmio ficou em 1,85\%, com franquia dedutível de $2 \%$ sobre o valor do risco, representando um prêmio total de US $\$ 2,5$ milhões.

No final de agosto de 1993 foi obtida a aprovação do produto pela LARC, através da resseguradora. Mas, na ocasião, a empresa exportadora já havia efetuado grande parte dos adiantamentos e não havia mais interesse em contratar o seguro para aquele ano. 
As operações de adiantamento e troca entre exportadores e produtores rurais eram regidas pelo Código Comercial Brasileiro através de um contrato desenvolvido pela Associação Nacional dos Exportadores de Cereais (ANEC), e, segundo MACHADO (1995), apresentavam as seguintes inconveniências:

- exigiam formalização do negócio através de escritura pública, quando da necessidade de acolher garantia hipotecária;

- exigiam a presença do comprador e do vendedor para a formalização do negócio;

- não permitiam ao credor transferir seus direitos para terceiros, exceto através de escritura pública;

- a concessão de fiança ou a realização do seguro garantia (performance), exigiam formalização de contrato à parte entre fiador e afiançado, ou entre seguradora e segurado, nos casos de seguro garantia;

- a execução judicial do vendedor para fins de exigir o cumprimento de sua obrigação era efetuada através de ação ordinária, de tramitação demorada;

- não permitiam a inclusão de seguro contra frustração de safra;

- não viabilizavam a criação de mercados secundários nem a comercialização em bolsas de mercadorias.

Devido a muitas dessas dificuldades, diversos setores do mercado se mobilizaram para desenvolver instrumentos que poderiam substituir com vantagens os contratos ANEC. O primeiro deles foi o Certificado de Mercadorias com Emissão Garantida (CMG), criado em julho de 1993, cujo fluxo operacional é mostrado na Figura 12. 
O CMG é um contrato mercantil voltado para comercialização a termo ${ }^{34}$ de mercadorias agropecuárias e agroindustriais negociadas em bolsas de mercadorias e de cereais. Para operacionalizar $\bigcirc \mathrm{CMG}$, foi criada uma câmara de compensação chamada Central de Registros S.A., cuja função é registrar, administrar as garantias, liqüidar os contratos físicos e divulgar informações de interesse dos mercados.

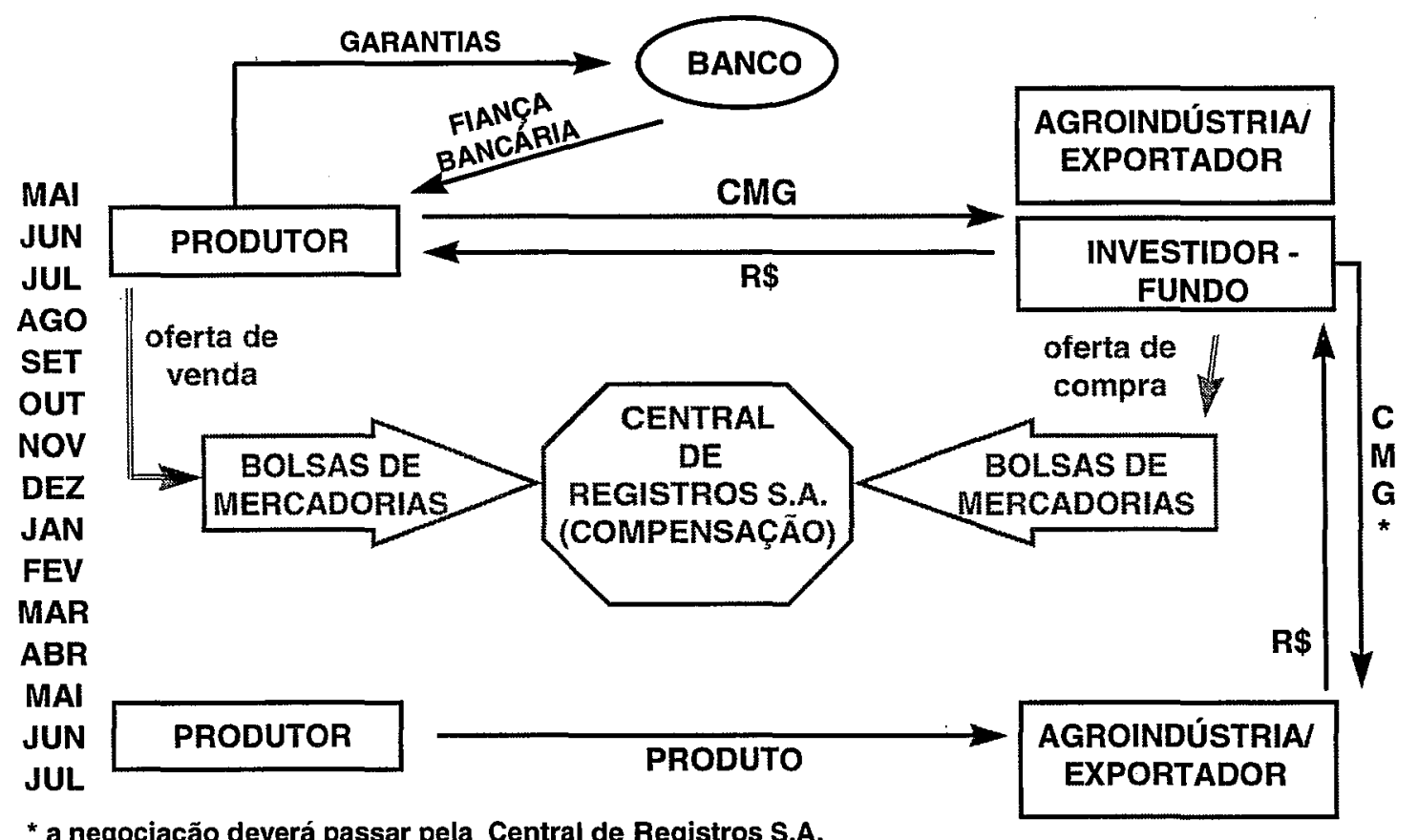

* a negociação deverá passar pela Central de Registros S.A.

Fonte: CAFFAGNI (1995)

Figura 12. Fluxo operacional do Certificado de Mercadorias com Emissão Garantida (CMG)

Em agosto de 1994, foi criada a Cédula de Produto Rural (CPR), através da Lei no 8.929. É uma cambial voltada para comercialização a termo de mercadorias produzidas por agricultores, pecuaristas e suas cooperativas. Seu fluxo operacional pode ser visto na Figura 13.

${ }^{34}$ Contrato a Termo: É um contrato que fixa antecipadamente o preço de determinada mercadoria, prevendo ou não adiantamento de recursos financeiros no ato da formalização do negócio. No caso dos contratos ANEC, CMG, CLB e CPR, as vendas a termo prevêem adiantamento de recursos, muitas vezes antes do plantio. 


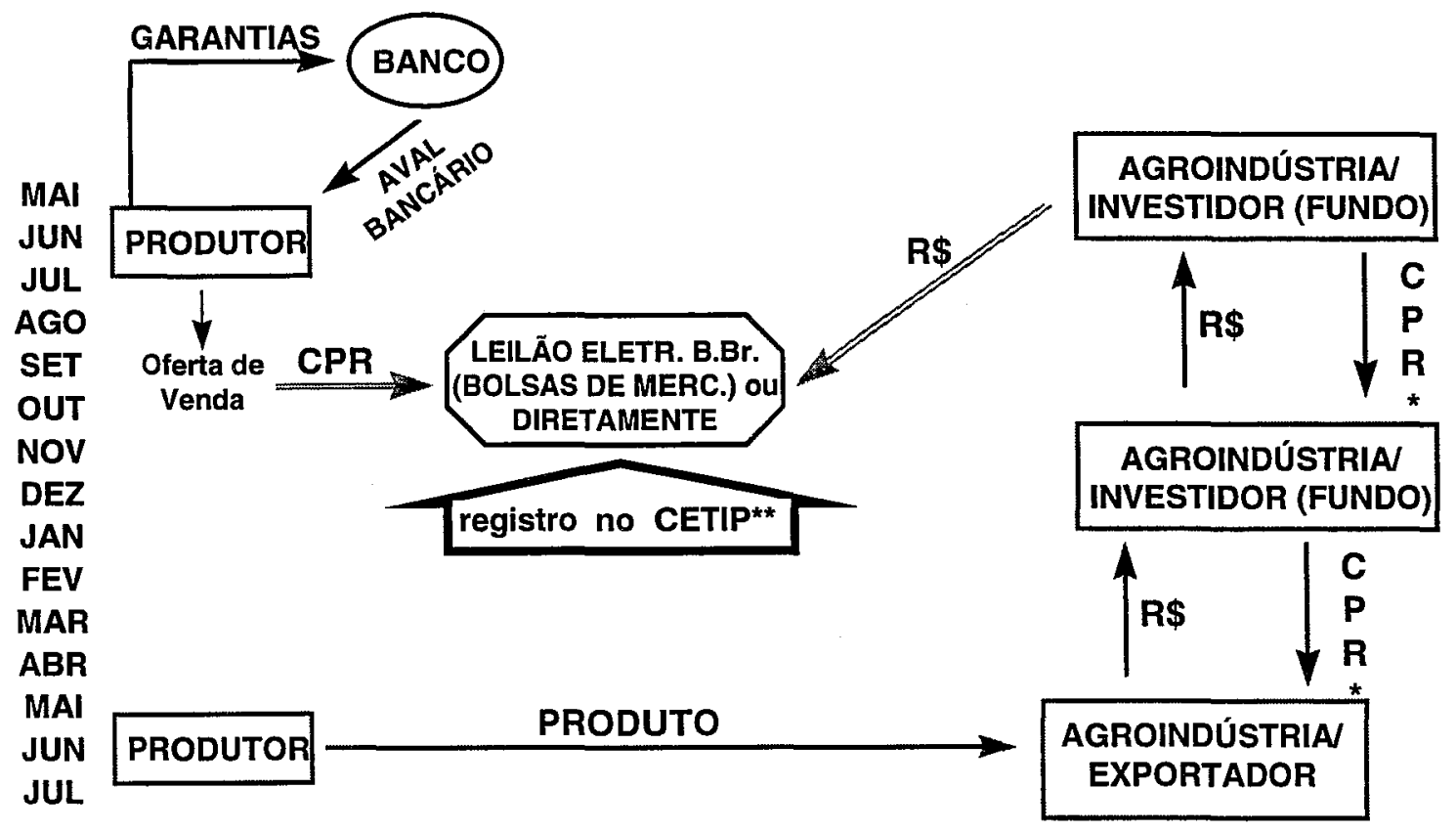

* transferência através de endosso

** Central de Custódia e de Liquidação Financeira de Títulos Privados

Fonte: CAFFAGNI (1995)

Figura 13. Fluxo operacional da Cédula de Produto Rural (CPR).

Em 1995, foi desenvolvido outro tipo de contrato, nos mesmos moldes do CMG, mas com possibilidade de a operação ser liqüidada em quatro anos, $25 \%$ ao ano. Essa modalidade chama-se Commodities Linked Bonds (CLB) e se aplica principalmente a adiantamentos de recursos para investimentos ${ }^{35}$, ou seja, tratores, implementos etc.

Nota-se que, nos contratos de "soja verde" e "troca" as responsabilidades são divididas entre produtor rural e exportadora, sendo que a última desempenha vários papéis que não fazem parte de seus objetivos, como fiscalizar e controlar, analisar crédito, fornecer recursos etc.

${ }^{35}$ O CLB também pode ser aplicado com prazos menores, como o CMG e a CPR. 
A criação desses novos papéis resultou na profissionalização das operações dividindo responsabilidades, antes assumidas pela exportadora, entre os vários segmentos do mercado. $O$ aumento do número de negócios fez crescer o volume financeiro empregado no sistema, através desses instrumentos, elevando os riscos de quebra generalizada de safra.

Diante disso, setores envolvidos no agribusiness, entre eles a Associação Brasileira de Agribusiness (ABAG), Associação Brasileira de Indústrias de Alimentos (ABIA), bolsas de mercadorias físicas e de futuros etc., mobilizaram-se para reivindicar a realização de um estudo sobre um modelo agrofinanceiro privado.

Atendendo parte dessa reivindicação, foi firmado um convênio entre a ABAG e o Departamento de Cooperativismo da Secretaria de Desenvolvimento Rural, do Ministério da Agricultura, do Abastecimento e da Reforma Agrária (DENACOOP MAARA), para contratação de um estudo, a ser realizado pela empresa Gerenseg Administração e Gerenciamento de Seguros Ltda., sobre as viabilidades operacional e mercadológica de um novo seguro rural. Em outubro de 1995, a Gerenseg vislumbrou um seguro rural com cobertura agregada, aprimorando aqueles estudos realizados em 1993 pela Rocha Azevedo Corretora de Seguros Ltda..

Um seguro com cobertura de riscos agregados de natureza catastrófica tem - objetivo de atender as operações de grandes empresas, com a seguinte configuração:

- cobertura das obrigações do produtor na entrega de mercadorias a agentes, com a qual se obtêm antecipadamente capitais e fatores de produção, ou seja, é um seguro contratado pelo financiador (segurado) para proteger-se contra a falta de entrega causada por perdas relacionadas a adversidades climáticas nos empreendimentos de seus fornecedores (produtores);

- beneficiários: traders, fornecedores de insumos, agroindústrias, indústrias alimentícias, investidores internos e externos; 
- como as operações são realizadas em vários estados brasileiros, estabelece-se uma grande distribuição geográfica de seguros, diminuindo o risco;

As coberturas desse seguro são:

- Seguro de catástrofes de natureza climatológica: cobre falhas na entrega em decorrência de riscos como incêndio, seca, chuvas excessivas, granizo, geada, ventos fortes, calor excessivo e algumas pragas e doenças incontroláveis;

- Seguro garantia de adiantamentos: garante a cobertura contra riscos morais, ou seja, quando um produtor, mesmo colhendo a lavoura objeto do seguro, não entrega o produto ao financiador, propositadamente;

- Seguro de estoque/trânsito de mercadorias: proporciona cobertura de transportes, desde a colheita ao armazém e, posteriormente, até sua entrega na indústria ou no corredor de exportação. Cobre riscos de incêndio, vendaval, transporte, transbordos e armazenagem e eventualmente, roubo de cargas;

- Seguro do patrimônio rural e seguro temporário de vida.

Em setembro de 1997, a Gerenseg tornou disponíveis os cálculos atualizados das taxas de risco puro dos estados de RS, PR, MG, MS, MT e GO, com os níveis de cobertura de 30 a $60 \%$ de perda de produção, entre as safras de 1984/85 e 1993/94, Tabela 11. A taxa de risco puro não considera o custo operacional, as reservas técnicas e o lucro da companhia; fornece a porcentagem de prêmio líqüido suficiente apenas para efetuar as eventuais perdas. 
Tabela 11. Probabilidade de Quebra de Safra de Soja por Estado, 1984/85 a 1993/94

\begin{tabular}{|c|c|c|c|c|c|}
\hline UF & $\begin{array}{c}\text { Produtividade } \\
\text { média } \\
\text { (sc/ha) }\end{array}$ & $\begin{array}{c}\text { Nível de } \\
\text { produtividade } \\
\text { segurada (\%) }\end{array}$ & $\begin{array}{c}\text { Produtividade } \\
\text { segurada } \\
\text { (sc/ha) }\end{array}$ & $\begin{array}{c}\text { Probabilidade } \\
\text { de perdas }\end{array}$ & $\begin{array}{c}\text { Taxa de } \\
\text { risco } \\
(\%) \\
\end{array}$ \\
\hline \multirow[t]{4}{*}{$\mathrm{RS}$} & 25,63 & 60 & 15,38 & 0,1842 & 7,452 \\
\hline & & 50 & 12,82 & 0,1305 & 5,816 \\
\hline & & 40 & 10,25 & 0,0887 & 4,558 \\
\hline & & 30 & 7,68 & 0,0091 & 3,663 \\
\hline \multirow[t]{4}{*}{ PR } & 33,95 & 60 & 20,37 & 0,0173 & 0.197 \\
\hline & & 50 & 16,98 & 0,0041 & 0.048 \\
\hline & & 40 & 13,58 & 0,0008 & 0,010 \\
\hline & & 30 & 10,18 & 0,0001 & 0,0002 \\
\hline \multirow[t]{4}{*}{ MG } & 32,00 & 60 & 19,20 & 0,0100 & 0,097 \\
\hline & & 50 & 16,00 & 0,0018 & 0,018 \\
\hline & & 40 & 12,80 & 0,0002 & 0,003 \\
\hline & & 30 & 9,60 & 0,0000 & 0,000 \\
\hline \multirow[t]{4}{*}{ MS } & 32,70 & 60 & 19,62 & 0,0043 & 0,034 \\
\hline & & 50 & 16,35 & 0,0005 & 0,004 \\
\hline & & 40 & 13,08 & 0,0000 & 0,000 \\
\hline & & 30 & 9,80 & 0,0000 & 0,000 \\
\hline \multirow[t]{4}{*}{ MT } & 37,25 & 60 & 22,35 & 0,0005 & 0,003 \\
\hline & & 50 & 18,62 & 0,0000 & 0,000 \\
\hline & & 40 & 14,90 & 0,0000 & 0,000 \\
\hline & & 30 & 11,17 & 0,0000 & 0,000 \\
\hline \multirow[t]{4}{*}{ GO } & 31,22 & 60 & 18,73 & 0,0425 & 0,670 \\
\hline & & 50 & 15,62 & 0,0157 & 0,259 \\
\hline & & 40 & 12,48 & 0,0049 & 0,090 \\
\hline & & 30 & 9,37 & 0,0013 & 0,028 \\
\hline \multirow[t]{4}{*}{$\mathrm{BR}$} & 30,62 & 60 & 18,37 & 0,0174 & 0,198 \\
\hline & & 50 & 15,32 & 0,0042 & 0,049 \\
\hline & & 40 & 12,25 & 0,0008 & 0,010 \\
\hline & & 30 & 11,02 & 0,0001 & 0,002 \\
\hline
\end{tabular}

Fonte: AZEVEDO (1997)

A mesma análise realizada em nível agregado no Brasil, de 1941 a 1993 e de 1974 a 1993, pode ser observada na Tabela 12. Nota-se que, no período mais recentemente, as taxas de risco apresentam valores menores, devido ao avanço tecnológico e à incorporação de áreas de fronteiras que possuem menores riscos climáticos; maiores produtividades e menores custos de produção (escala). 
Tabela 12. Taxas de Risco para Soja em Diferentes Níveis de Cobertura

\begin{tabular}{cccccc}
\hline BR & $\begin{array}{c}\text { Nível de 70\% } \\
\text { de } \\
\text { produtividade }\end{array}$ & $\begin{array}{c}\text { Nível de } 60 \% \\
\text { de } \\
\text { produtividade }\end{array}$ & $\begin{array}{c}\text { Nível de } 50 \% \\
\text { de } \\
\text { produtividade }\end{array}$ & $\begin{array}{c}\text { Nível de } 40 \% \\
\text { de } \\
\text { produtividade }\end{array}$ & $\begin{array}{c}\text { Nível de } 30 \% \\
\text { de } \\
\text { produtividade }\end{array}$ \\
\hline $\begin{array}{c}1941 \\
\text { a }\end{array}$ & $2,41 \%$ & $1,25 \%$ & $0,59 \%$ & $0,26 \%$ & $0,11 \%$ \\
1993 & & & & & \\
1974 \\
$\begin{array}{c}a \\
1993\end{array}$ & $1,06 \%$ & $0,40 \%$ & $0,13 \%$ & $0,04 \%$ & $0,01 \%$ \\
\hline
\end{tabular}

Fonte: AZEVEDO (1997)

Pode-se observar que, segundo o estudo acima, as taxas de risco de alguns estados apresentam níveis extremamente baixos, exatamente pelo fato de, no período estudado, não terem havido grandes quebras de safra. Sabe-se também que as regiões de fronteira, principalmente MT e MS, apresentam ótima regularidade no regime de chuvas. Entretanto, para uma análise mais aprofundada, seria necessário levantar dados históricos de resultados de companhias seguradoras, inexistentes, uma vez que as taxas apresentadas poderiam elevar-se devido ao risco moral e à seleção adversa.

Outras alternativas foram apresentadas pela Gerenseg, sempre para a lavoura de soja, visto que, nesse primeiro momento, haveria maior facilidade de encontrar resseguradoras privadas internacionais dispostas a aceitar as operações. Até o momento, várias propostas foram apresentadas por empresas e a expectativa é de que o seguro garantia venha a ser operacionalizado para as próximas safras.

A BRASILSEG, seguradora do Banco do Brasil, está em fase final de estudos para poder vincular às CPRs avalizadas pelo banco um seguro garantia, com a finalidade de diminuir o risco no caso de frustração de safra e, conseqüentemente, diminuir o custo do aval cobrado na operação. Esse instrumento poderia gerar mais liqüidez no mercado de CPR, uma vez que, diminuindo-se o custo do aval e o risco do banco, haveria mais interessados no produto. Esse aumento de liqüidez também 
diminuiria a demanda por crédito rural formal ${ }^{36}$, desafogando o orçamento do governo ou destinando crédito subsidiado a setores mais necessitados.

\subsection{Seguros Rurais Utilizando Mercados Futuros}

Neste século desenvolveram-se instrumentos privados eficientes de transferência de riscos de preços, através de mercados futuros e de opções. Esperase que esse grande mercado possa assumir um importante papel como alternativa de política agrícola com menor participação do governo.

No caso de seguros rurais, como o volume produzido possui relação inversa ao preço, pode-se considerar que uma proteção ou transferência dos riscos de preços, através dos mercados futuros e de opções, talvez resultem em modelos eficientes de diminuição do risco de produção a serem desenvolvidos no futuro.

Essa seção levantará sugestões relacionadas a métodos de diminuição do risco de produção utilizando os mercados futuros e de opções. Para tanto, serão definidos brevemente os referidos mercados, procurando-se apenas dar as características fundamentais dos sistemas, necessárias para posterior compreensão. Mais informações podem ser obtidas em MARQUES \& MELLO (1997) e HULL (1996).

Os mercados futuros têm como objetivo negociar contratos referentes a expectativas futuras de preços e índices de commodities, ativos financeiros, serviços etc., ou seja, um contrato futuro é o compromisso de comprar ou vender determinado ativo em uma data futura, por um preço previamente estabelecido.

A fixação de preços futuros (em uma determinada data presente) abre a possibilidade de compradores e vendedores optarem por trabalhar sem o risco de

\footnotetext{
${ }^{36}$ O crédito rural formal é aquele fornecido pelo Sistema Nacional de Crédito Rural, com recursos subsidiados oriundos do orçamento do governo, de exigibilidades bancárias, da poupança verde etc.
} 
oscilações indesejáveis de preços dos produtos negociados. O detentor de um ativo, ou mercadoria, tem receio de que o preço caia enquanto estiver de posse do mesmo, analogamente ao comprador, que quando necessita adquirir determinado ativo ou mercadoria, não deseja que os preços subam.

O princípio fundamental dos mercados futuros baseia-se no conceito de que as cotações do mês futuro, de um ativo ou de uma mercadoria, convergem para o preço físico no vencimento do contrato. Assuma-se que um produtor venda parte de sua safra para um determinado mês futuro. Se nos dias subseqüentes ao fechamento do contrato o preço futuro, referente ao mesmo mês, for negociado a níveis mais baixos, o produtor receberá diariamente um ajuste positivo, visto que vendeu a um preço mais alto anteriormente. O preço de seu produto físico, porém, também se desvalorizou no decorrer do mesmo período, anulando, assim, os ganhos recebidos provenientes dos ajustes diários totalizando-se o preço objetivo pretendido inicialmente. $O$ inverso também poderá acontecer, se, após o produtor ter vendido contratos para vencimento em um mês futuro, o preço para o mesmo mês for negociado a níveis mais altos. Nesse caso, o produtor diariamente pagará um ajuste da diferença, mas, em contrapartida, seu produto físico se valorizará e seu saldo líqüido atingirá o preço objetivo inicial. No caso do comprador, deve-se desenvolver um raciocínio análogo, visto que também procura fixação antecipada de preços para proteger-se contra eventuais altas.

Esses dois agentes têm pelo menos uma característica em comum: necessitam de proteção contra oscilações contrárias de preços. São chamados de hedgers.

Nesse mercado, também existem agentes que compram e vendem contratos interessados apenas em auferir ganhos das oscilações de preços, não tendo nenhuma afinidade com o objeto de negociação; são chamados de especuladores. A função principal dos especuladores é oferecer liqüidez à negociação de determinada mercadoria ou ativo, inibindo manipulação de mercado. 
O mercado de opções está intimamente ligado a preços futuros. Nele, negociam-se direitos e obrigações de comprar ou vender uma commodity física, um ativo financeiro ou contratos futuros, a um preço previamente estabelecido (CHICAGO BOARD OF TRADE, 1985).

No mercado de opções, o comprador (ou titular) paga um prêmio pelo direito de vender ou comprar determinado bem e o vendedor (ou lançador) recebe um prêmio pela obrigação de comprar ou vender o mesmo bem, respectivamente, conforme a Figura 14.

\begin{tabular}{|c|c|c|}
\cline { 2 - 3 } \multicolumn{1}{c|}{} & $\begin{array}{c}\text { COMPRADOR (TITULAR) } \\
\text { PAGA PRÊMIO }\end{array}$ & $\begin{array}{c}\text { VENDEDOR (LANÇADOR) } \\
\text { RECEBE PRÊMIO }\end{array}$ \\
\hline $\begin{array}{c}\text { OPÇÕES DE COMPRA } \\
\text { (CALLS) }\end{array}$ & DIREITO DE COMPRAR & OBRIGAÇÂOO DE VENDER \\
\hline $\begin{array}{c}\text { OPÇÕES DE VENDA } \\
(\text { PUTS })\end{array}$ & DIREITO DE VENDER & OBRIGAÇÃO DE COMPRAR \\
\hline
\end{tabular}

Fonte: CAFFAGNI (1995)

Figura 14. Tipos de agentes e contratos dos mercados de opções

O mercado de opções também pode fornecer proteção para os hedgers. Considere-se, aqui, um produtor rural de soja que, por ocasião do plantio, outubro, decidiu proteger-se contra o risco de queda de preços para a época da colheita, maio. Entretanto, não queria abrir mão de aproveitar uma eventual alta de preços, caso houvesse. Através de seu corretor de futuros, deu ordem de compra de opções de venda para maio (data de vencimento ou exercício), pagando um prêmio por isto. Portanto, o produtor comprou o direito (ao pagar o prêmio) de vender certa quantidade de soja ao preço contratado para maio e o vendedor da opção recebeu o prêmio em troca da obrigação de comprar a soja em maio ao preço negociado. Caso o preço de mercado esteja menor que de exercício (contratado), o produtor exerce a opção e entrega a soja ao vendedor da opção ao preço contratado. Se o preço de mercado estiver acima do preço contratado, o produtor não exerce a opção e vende a soja no mercado.

Como exemplo de opção de compra, considere-se uma indústria processadora de soja que busca proteção contra a alta de preços, mas que não quer 
deixar de adquirir o produto mais barato caso o preço caia. Nesse caso, deverá comprar opções de compra de soja para maio. Isto é, a indústria pagará um prêmio em troca do direito de comprar certa quantidade de soja em maio. O vendedor dessa opção de compra estará recebendo um prêmio que o obrigará a vender soja para a indústria ao preço negociado, caso seja exercido. Se o preço subir, a indústria exerce a opção e recebe a soja ao preço contratado. Se o preço cair, o vendedor da opção de compra não será exercido, pois a indústria tem o direito de optar e comprar o produto mais barato no mercado.

As negociações, tanto nos mercados futuros como no de opções, são feitas em bolsas de mercadorias que transacionam contratos futuros, através de pregões (ato de apregoar determinada oferta ou demanda) que, na maioria das vezes, realizam-se em "viva voz". As bolsas de mercadorias são sociedades sem fins lucrativos, com o objetivo de propiciar condições para que as negociações tenham principalmente transparência, segurança e liqüidez.

Além de hedgers e especuladores, existem outros participantes do sistema como corretores, operadores de pregão, conselhos consultivos, juizes etc.

Os mercados futuros possuem também órgãos fiscalizadores, garantidores e regulamentadores das operações realizadas, além de contar com fiscalização do Banco Central, da Comissão de Valores Mobiliários e da Receita Federal.

No Brasil, existe atualmente apenas uma bolsa que negocia volumes expressivos de contratos futuros agropecuários, a Bolsa de Mercadorias e Futuros (BM\&F), que, além de possuir futuros financeiros, negocia contratos futuros de boi, café, soja, açúcar, algodão e milho. 


\subsubsection{Seguro de Opções de Produtividade nos EUA}

Apesar dos diversos tipos de programas norte-americanos apresentados no Capítulo 5, pode-se considerar que o mercado de seguros agrários daquele país, apesar de desenvolvido, não apresenta resultados satisfatórios.

A partir de 1980, iniciou-se um programa de assistência a desastres com um seguro rural individual, de responsabilidade das seguradoras privadas. Em troca, o governo autorizou o subsídio dos prêmios, através da FCIC, e ofereceu resseguro às perdas catastróficas. Entre 1981 e 1990, as indenizações excederam o valor dos prêmios em US $\$ 2,5$ bilhões, mas as seguradoras obtiveram lucros. O escritório Geral de Contabilidade dos EUA estimou que, sob o pior cenário, as seguradoras assumiram apenas $2 \%$ das perdas, enquanto o governo assumiu $98 \%{ }^{37}$.

Estes dados levam ao questionamento da possibilidade do desenvolvimento dos seguros privados, sem forte intervenção governamental.

${ }^{37}$ Os gastos governamentais com políticas agropecuárias têm sido fortemente combatidos por diversos segmentos econômicos não agrários. Segundo o editorial do dia 14 de setembro de 1992, publicado no Washington Journal, o USDA possui escritórios em $94 \%$ dos municípios norte-americanos. A evolução e a tendência do número de funcionários e produtores têm obedecido uma relação inversa, como pode ser observado na tabela abaixo.

Evolução e Tendência dos números de Funcionários do USDA e números de Produtores NorteAmericanos, entre 1950 e 2001

\begin{tabular}{ccc}
\hline & Produtores (milhões) & Funcionários do USDA (milhões) \\
\hline 1950 & 10 & 0,084 \\
\hline 1990 & 2,4 & 0,129 \\
\hline 2001 & 0,145 & 0,146 \\
\hline
\end{tabular}

O mesmo artigo afirma que, em 1991, de um total de US\$ 52 bilhões do orçamento destinados ao setor rural, US\$ 30 bilhões foram gastos com subsídios. A Organization for Economic Cooperation and Development estima que, entre subsídios e preços altos dos produtos agropecuários para os consumidores, o custo da política agrária norte-americana possa chegar a US $\$ 58$ bilhões/ano. 
Podem-se destacar três importantes fatores que influenciam os resultados da atividade seguradora: os riscos sistêmicos climáticos, o risco moral e a seleção adversa. Os riscos sistêmicos, já discutidos com a terminologia de eventos generalizados (subseção 4.2.2), são aqueles que possuem propriedades endêmicas, ou sejam, não são estatisticamente independentes. Essa característica não dá oportunidade às seguradoras de diversificarem seus riscos através de plantações e criações em outras regiões.

Os riscos sistêmicos podem ser minimizados através das seguintes políticas:

(a) Divisão dos riscos com resseguradoras internacionais: Sem a atuação governamental, as grandes resseguradoras preferem não participar intensivamente do ramo agrário;

(b) Atuação do governo como órgão ressegurador: Sua eficiência é discutível porque não contribui para o desenvolvimento do mercado segurador, como já discutido;

(c) Utilização do mercado de opções de preços: Essa alternativa será detalhada adiante, na subseção 6.3.2;

(d) Utilização do mercado de opções de produtividade.

Os contratos de opções de produtividade foram primeiramente propostos por Halcrow em 1949 (MIRANDA \& CLAUBER, 1995). Em junho de 1995, a Chicago Board of Trade (CBOT) lançou os contratos futuros e de opções de produtividade de milho para o Estado de lowa. Em janeiro de 1996, os contratos foram estendidos para os estados de Illinois, Indiana, Ohio e Nebraska.

Os contratos de opções de produtividade utilizam os mesmos princípios e fundamentos dos contratos de opções de preços, criados em 1982. 
Antes do plantio, para um produtor garantir-se contra uma eventual quebra de safra, pode comprar contratos de opção de venda de determinada produtividade de milho, soja, sorgo, trigo e cevada ${ }^{38}$, para a época de sua colheita. O USDA estima a produtividade para a época da colheita e o mercado negocia o valor do prêmio que reflete suas expectativas quanto às produtividades futuras.

Exemplificando: suponha-se que um produtor tenha a intenção de plantar 80 acres de milho em determinado estado norte-americano e que deseje segurar a produtividade futura. $\mathrm{Na}$ época do plantio, para uma produtividade média estadual futura de $130 \mathrm{bu} / a c$ (na época da colheita), os prêmios das opções de venda de produtividades para aquele estado estarão sendo negociados na CBOT a 8 bu/ac. Ou seja, para que o produtor garanta uma produtividade média estadual de $130 \mathrm{bu} / \mathrm{ac}$, é necessário o pagamento de um prêmio de $8 \mathrm{bu} / \mathrm{ac}$.

Como essas produtividades precisam ser relacionadas a valores monetários, cada contrato vale US $\$ 100,00$ multiplicados pela produtividade estimada pelo USDA, ou seja, se a produtividade estimada pelo USDA são $130 \mathrm{bu} / \mathrm{ac}$, o contrato valerá 130 bu/ac $x$ US $\$ 100,00=$ US $\$ 13.000,00$.

Desse modo, suponha-se que o preço esperado, fixado no mercado a termo ou no mercado futuro, sejam US\$2,5/bu. Então, o valor da produção esperada será igual a:

$130 \mathrm{bu} / \mathrm{ac} \times 80 \mathrm{ac} \times$ US $\$ 2,5 / \mathrm{bu}=$ US $\$ 26.000,00=2$ contratos

Pode-se utilizar um método similar, através da fórmula (3), para o cálculo do número de contratos:

$$
\frac{P E}{100} \times A=C
$$

\footnotetext{
${ }^{38}$ Até 1996 , apenas esses produtos, e somente para alguns estados, estavam disponíveis.
} 
onde,

$\mathrm{PE}=$ Preço esperado;

100 = multiplicador do contrato;

$A=$ área;

$\mathrm{C}=$ número de contratos.

$$
\frac{2,5}{100} \times 80=2 \text { contratos }
$$

Assim, o produtor deverá comprar dois contratos de opções de venda de produtividade a $130 \mathrm{bu} / \mathrm{ac}$, com vencimento na época de colheita, pagando 8 bu/ac por esse direito.

Por ocasião da colheita, caso a produtividade do estado calculada pelo USDA caia para 109 bu/ac, o produtor exerce a opção e recebe a diferença entre 130 e 109 bu/ac, ou 21 bu/ac. Mas, como há necessidade de transformar essa produtividade em valor monetário, para que o vendedor da opção de venda realize $\circ$ pagamento, multiplicam-se os 21 bu/ac por US $\$ 100,00$ e, em seguida, pelo número de contratos.

A Tabela 13 apresenta uma simulação dos diversos resultados da utilização ou não dos contratos de produtividade. Com a utilização do contrato de opções de produtividade, o produtor garantiu uma receita bruta de US\$24.400,00, mesmo havendo uma quebra de produtividade estadual de $16,2 \%$. Caso não utilizasse nada e não houvesse nenhum problema climático, sua receita bruta alcançaria US\$ $27.000,00$, Entretanto, se na mesma situação houvesse perda, sua receita bruta cairia para US\$21.800,00. 
Tabela 13. Simulação de Resultados com Contratos de Opções de Produtividade

\begin{tabular}{|c|c|c|c|c|}
\hline & \multicolumn{2}{|c|}{$\begin{array}{l}\text { Utilizando Contratos de } \\
\text { Opções }\end{array}$} & \multicolumn{2}{|c|}{ Sem Utilizar Contr. de Opções } \\
\hline & $\begin{array}{l}\text { quebra de } \\
\text { safra }\end{array}$ & safra normal & safra normal & $\begin{array}{l}\text { quebra de } \\
\text { safra }\end{array}$ \\
\hline Área (acres) & & & 0 & \\
\hline $\begin{array}{l}\text { Produtividade Segurada } \\
\text { (bu/ac) }\end{array}$ & 130 & 130 & & \\
\hline Preço esperado (US\$/bu) & & & 5 & \\
\hline Número de contratos & 2 & 2 & & \\
\hline Prêmio (bu/ac) & 8 & 8 & & \\
\hline Total pago (US\$) & 1.600 & 1.600 & & \\
\hline Colheita (bu/ac) & 109 & 135 & 135 & 109 \\
\hline Diferença recebida (bu/ac) & 21 & 0 & & \\
\hline Total recebido (US\$) & 4.200 & 0 & & \\
\hline Líqüido (US\$) & +2.600 & -1.600 & & \\
\hline Venda da safra (US\$) & 21.800 & 27.000 & 27.000 & 21.800 \\
\hline Resultado (US\$) & $24.400,00$ & $25.400,00$ & $27.000,00$ & $21.800,00$ \\
\hline
\end{tabular}

Fonte: CHICAGO BOARD OF TRADE (1995), adaptada pela pesquisa

Nota-se que essa alternativa de seguro rural está baseada nas produtividades médias dos estados. Assim, se a produtividade calculada pelo USDA apresentar diminuição e a produtividade de um produtor (contratado) do mesmo estado não seguir a mesma movimentação e, por exemplo, subir, ele irá receber a diferença entre o índice contratado e o calculado pelo USDA. Inversamente, se o produtor for atingido por um sinistro localizado (granizo ou inundação, por exemplo), deprimindo sua produtividade, mas a média do estado não acompanhar a queda na mesma proporção, a indenização não corresponderá ao valor da diminuição local de produtividade. 
Desse modo, antes de comprar contratos de opção de produtividade, deve-se verificar se a produtividade individual possui alta correlação com a produtividade média do estado.

A principal vantagem desses contratošs é a eliminação definitiva do risco moral e da seleção adversa, uma vez que sua liqüidação é realizada por um índice de produtividades médias determinado pelo USDA.

Essa alternativa de seguro abre diversas possibilidades operacionais, como o produtor travar uma receita utilizando os mercados de opções de preços. Nesse caso, além de comprar contratos de opções de venda de produtividades, deve adquirir, para o mesmo vencimento, contratos de opções de venda a um determinado preço, garantindo assim, em troca do pagamento de um prêmio, uma receita mínima.

\subsubsection{Modelo Hedging-Griffo Corretora de Mercadorias ${ }^{39}$}

Esse modelo inspirou-se nas experiências de produtores de café atingidos pela forte geada de 1994. Naquela ocasião, o preço pago pelo café brasileiro saiu dos US\$118,37/sc em maio, alcançando US\$211,81/sc em agosto, no mercado físico em Nova lorque (AGRIANUAL, 1997).

Basicamente, o modelo consiste na utilização dos mercados de opções, com o objetivo de propiciar ao produtor uma cobertura que lhe garantirá formar novamente a lavoura atingida, nos três anos seguintes. Ou seja, se houver uma forte geada, o preço do café deverá subir, gerando uma receita adicional ao produtor que estiver posicionado no mercado de opções.

39 Este modelo foi apresentado por PEREIRA (1996) durante o "Seminário de Estratégias Operacionais para os Mercados de Boi e Café", promovido pela Bolsa de Mercadorias \& Futuros (BM\&F) e coordenado pelo Centro de Estudos Avançados em Economia Aplicada (Cepea). 
De acordo com expectativas do mercado em maio de 1994, o prêmio de uma opção de compra de US $\$ 165,00 / \mathrm{sc}$ em Nova lorque com vencimento em agosto era US\$ 1,50/sc. Ou seja, para se ter o direito de comprar café a um preço de US\$ $165,00 /$ sc na época do vencimento da opção, pagava-se um prêmio de apenas US\$ $1,50 / \mathrm{sc}$, devido ao excesso de estoques mundiais, somado às expectativas de uma grande colheita brasileira. Quem comprou essa opção recebeu o direito de adquirir café em agosto, que alcançou US\$211,81/sc, a um preço de US\$165,00/sc, resultando em uma receita líqüida de US\$ 45,31/sc.

Utilizando os níveis de preços e prêmios de 1994 como exemplo, suponha-se que um cafeicultor desejasse realizar um seguro rural de sua plantação de café contra a ocorrência de uma forte geada, que poderia resultar na morte de sua plantação. Nesse caso, a cobertura deveria permitir a reconstituição de sua lavoura até o estágio de produção, isto é, garantir todos os custos fixos e variáveis durante os três primeiros anos após a geada.

De acordo com dados da AGRIANUAL (1997), o custo de formação de café adensado até o terceiro ano, quando a lavoura começa a produzir a níveis comerciais, são US\$ 6.609,00/ha, ou seja, o valor que se deseja garantir.

Para realizar o seguro, o produtor poderia comprar contratos de opções de compra ao preço de vencimento de US $\$ 165,00 / s c$, pagando um prêmio de US\$ $1,50 /$ sc. Como a ocorrência da geada elevou o preço para US\$211,81, a receita líqüida que o cafeicultor obteve foram de US\$45,31/sc, conforme a fórmula (4):

$$
(U S \$ p m / s c-U S \$ p o / s c)-U S \$ p r / s c=U S \$ r l / s c
$$

onde:

pm = preço de mercado no vencimento da opção;

po $=$ preço da opção; 
pr = valor do prêmio;

rl = receita líqüida por saca de café.

(US $\$ 211,81 / \mathrm{sc}-$ US $\$ 165,00 / \mathrm{sc}$ ) - US $\$ 1,50 / \mathrm{sc}=$ US $\$ 45,31 / \mathrm{sc}$

Partindo-se da hipótese de que cada saca de café propiciaria uma receita de US\$ 45,31/sc, quantas sacas de café o produtor deveria comprar de opção de compra, a US\$1,50/sc, para garantir uma receita total de US\$6.609,00/ha, no caso de geada forte?

$$
\text { US } \$ 6.609,00 / \mathrm{ha} \div \text { US } \$ 45,31 / \mathrm{sc}=145,86 \mathrm{sc} \cong 146 \mathrm{sc}
$$

O produtor deveria comprar $146 \mathrm{sc}^{40}$, cujo valor do prêmio por hectare seria:

$$
146 \mathrm{sc} \times \text { US\$ } 1,50 / \mathrm{sc}=\text { US\$219,00/ha }
$$

Ou 3,3\% em relação ao valor da cobertura.

Atualmente, as expectativas de agentes de mercado estimam um volume baixo de estoques mundiais, aliado a uma oferta relativamente justa em relação à demanda. O preço futuro do café cotado na BM\&F no final de janeiro de 1998 para setembro, eram de US\$164,50/sc e o valor do prêmio de uma opção de compra a US $\$ 165,00$ custaria aproximadamente US $\$ 30,00 / \mathrm{sc}$, representando um valor muito alto para se trabalhar uma estratégia.

${ }^{40}$ O tamanho de um contrato de opção de café são $100 \mathrm{sc}$ de $60 \mathrm{~kg}$, sendo permitida a negociação apenas de valores múltiplos de 100 sacas. Mas, para efeito de simplificação do exemplo, considerou-se a negociação em sacas. 
Mas, segundo consultores do mercado de café, se houver uma forte geada no inverno brasileiro de 1998 , o preço poderá alcançar US\$ 400,00/sc. O mercado de café negociado na BM\&F estaria disposto a aceitar a compra de uma opção de compra de US $\$ 310,00 / \mathrm{sc}$, com vencimento em agosto, a um valor de prêmio de US\$3,00/sc. Se a ocorrência de uma geada forte possibilitar uma oscilação de US\$310,00/sc para US $\$ 400,00 / s c$, o produtor poderá proteger-se comprando opções de compra a US\$ $310,00 / \mathrm{sc}$.

Caso haja uma forte geada e o preço suba para US $\$ 400,00 / s c$, o produtor exercerá seu direito de comprar café a US\$310,00/sc. Ou seja, sua receita líqüida da opção de compra a US $\$ 310,00 / s c$, cujo prêmio foram de US $\$ 3,00 /$ sc, serão:

(US\$ $400,00 / s c-$ US $\$ 310,00 / \mathrm{sc}$ ) - US\$ $3,00 / \mathrm{sc}=$ US $\$ 87,00 / \mathrm{sc}$

Diante dessa receita por saca, o cafeicultor deverá comprar 76 sacas de opções de compra, que é o valor que deseja cobrir dividido pela receita por saca. Assim:

$$
\text { US } \$ 6.609,00 / \text { ha } \div \text { US } \$ 87,00 / \mathrm{sc}=75,97 \mathrm{sc} \cong 76 \mathrm{sc}
$$

O valor do prêmio será de $76 \mathrm{sc} \times$ US\$ $3,00 / \mathrm{sc}=$ US $\$ 228,00 /$ ha ou $3,4 \%$, em relação ao valor da cobertura.

Embora esse tipo de seguro possua hipóteses fortes, como a alta correlação entre os preços e a intensidade da geada, há necessidade de se aprimorar o modelo porque, conforme as expectativas do mercado e a estratégia utilizada (conjugando opções de compra com opções de venda), pode-se desenvolver uma alternativa eficiente para o cafeicultor.

Deve-se lembrar que esse modelo pode funcionar no mercado de café devido às fortes oscilações de preços a que está sujeito por ocorrência de geadas no Brasil, uma vez que o país responde por aproximadamente $30 \%$ da produção mundial. 


\section{MATERIAL E MÉTODOS}

Depois de definir seguros rurais, realizar uma evolução histórica até os momentos mais recentes no Brasil, detectar novas propostas brasileiras, caracterizar as modalidades de seguros nos EUA e levantar alguns modelos alternativos, é necessário realizar uma pesquisa dirigida que auxiliará nas discussões, tanto sobre os pontos polêmicos, quanto sobre a validade dos modelos alternativos.

Os pontos polêmicos referem-se a tipos e níveis de coberturas, papel do Proagro, responsabilidades entre seguradoras e resseguradoras, problemas com fraudes, necessidade de um fundo de estabilidade e intervenção governamental.

A validade dos modelos alternativos está abordada na implementação de cooperativas e associações de fundos mútuos, na possibilidade de utilizar mercados futuros e de opções para diminuir risco de produção e na utilização de um seguro acoplado à CPR.

Essa pesquisa dirigida procurará buscar opiniões de profissionais que atuam no agribusiness e que, de alguma maneira, dependem direta e indiretamente da produção e da renda do empresário rural.

As pesquisas científicas podem ser realizadas sob três aspectos: experimental, descritiva e explanatória (BOYD E WESTEFALL, 1964 ${ }^{41}$ ) op. cit. in ROCHA (1994). As pesquisas experimentais destinam-se a testar hipóteses; as descritivas levantam as características dos fenômenos, procurando classificar, explicar e interpretá-los; as explanatórias tentam descobrir novas relações, identificando problemas, contribuindo para a realização de futuros estudos.

${ }^{41}$ BOYD JR., H.W.; WESTEFALL, R. Pesquisa Mercadológica. Rio de Janeiro: Fundação Getúlio Vargas, 1964. 314 p. 
Para alcançar os objetivos deste trabalho, apenas dois métodos poderiam ser utilizados:

(a) Pesquisa experimental, enviando-se questionários a diversos setores do agribusiness com representatividade aceita estatisticamente, ou seja, procurando alcançá-los por uma listagem de endereços em um universo suficientemente grande, a ponto de as respostas poderem ser testadas estatisticamente;

(b) Pesquisa explanatória, adotando-se questionários e entrevistas com as principais lideranças do setor agropecuário previamente selecionadas, buscando identificar sugestões para problemas e novas propostas. $O$ universo a ser pesquisado, neste caso, é bem menor e não pode ser justificado estatisticamente; entretanto, as questões são mais profundas e a relação pesquisador/pesquisado tem um caráter personalizado.

O primeiro método, pela necessidade em se pesquisar um maior número de agentes, não garantiria um aprofundamento técnico específico de seguro rural. Desse modo, o questionário precisaria conter o máximo de perguntas sobre aspectos gerais, com questões fechadas e de múltipla escolha.

O segundo método, embora utilize uma amostra não-probabilística ${ }^{42}$, possui a vantagem de ser direcionado a indivíduos que possuem maior compromisso com o objeto do estudo. As perguntas podem ser abertas e mais aprofundadas, dando a oportunidade ao pesquisado de emitir sua opinião livremente e, muitas vezes, sem qualquer limitação.

\footnotetext{
$42 \mathrm{Na}$ amostra não-probabilística, não há como estimar a probabilidade de cada elemento ser incluído na amostra, não existindo segurança de que todos os elementos tenham a oportunidade sê-lo (SELLTIZ, J.; DEUTSCH, M.; COOK, S.W. Método de Pesquisa nas Relações Sociais. São Paulo: Editora Pedagógica e Universitária Ltda., 1995. 687 p.) op. cit. in ROCHA (1994).
} 
A escolha de um dos dois métodos deve levar em consideração principalmente os objetivos do trabalho. De acordo com os resultados que se pretendem alcançar, deve-se escolher o tipo de análise e seu grau de dificuldade técnica. Logicamente, todo pesquisador deseja um maior universo possível para sua pesquisa, mas, enquanto se ganha em representatividade por número de indivíduos, perde-se em profundidade de discussão. Nessa dissertação, optou-se pela utilização do segundo método de pesquisa, uma vez que o tema apresenta questões técnicas que exigem familiaridade com o assunto.

$\mathrm{Na}$ escolha da amostra, procurou-se alcançar profissionais que ocupam cargos decisórios nos setores de produção, processamento, comercialização, agentes financeiros e de sẹguros rurais. Optou-se, também, por realizar primeiramente um contato telefônico com cada um dos pesquisados para detectar a disponibilidade em responder ao questionário.

Para realizar a pesquisa, foi elaborado um questionário com três questões de múltipla escolha e 14 questões abertas (Apêndice). Foram enviados 46 questionários por correio e o índice de respostas alcançou $65,3 \%$ ou retorno de 30 questionários, que pode ser considerado bom, levando-se em consideração o grande número de perguntas abertas e complexas, que necessitam de algum trabalho para serem respondidas.

Procurou-se investigar primeiramente o que o setor pesquisado pensava em relação ao valor de referência que o seguro rural deve cobrir nos casos em que o produtor utiliza recursos próprios, crédito rural ou venda antecipada (por exemplo CPR): Uma vez que algumas modalidades de seguros, principalmente norteamericanas, começam a utilizar o conceito de cobertura de receita esperada, deve-se saber se o agribusiness nacional considera importante o desenvolvimento desse tipo de seguro.

Ainda com relação à cobertura, foram perguntados qual a porcentagem e os tipos de ocorrências que o seguro rural deveria cobrir. $O$ valor do prêmio também foi 
abordado porque, no início dos anos 90 , a cada ano em que o Proagro e algumas companhias de seguros apresentavam resultados negativos, os déficits entravam nos cálculos do prêmio para o ano seguinte, fazendo com que as taxas, em alguns anos atingissem patamares altos. Esse procedimento acabou por expelir do sistema os produtores com menores riscos, que não viam vantagem no elevado custo em relação ao risco apresentado. Como o mal desempenho dos seguros rurais tinha estreita relação com o aumento do número de fraudes, questionou-se quais as medidas necessárias para inibir as fraudes.

Em um momento em que se debate, entre vários setores da sociedade, o verdadeiro papel que o Estado deve assumir perante os diversos mercados, foi perguntado qual o papel do Proagro e das seguradoras privadas. Também foi questionado se haveria necessidade de o governo subsidiar o setor de seguros rurais no Brasil.

Perguntou-se, também, a respeito da validade do zoneamento agrícola adotado pelo Proagro, visto ser essa sua principal mudança técnica a partir de 1996.

Devido à quebra do monopólio estatal no mercado de resseguros e ao crescente interesse de grandes resseguradoras internacionais em alguns tipos de seguros nacionais, abordou-se o grau de comprometimento das resseguradoras nacionais e internacionais no mercado segurador.

Em todo o mundo, existem diversas cooperativas e associações de seguros mútuos; procurou-se, então, saber se essa alternativa poderia ser implementada no Brasil.

Abordando as garantias do sistema, não se poderia deixar de analisar o que os entrevistados achavam sobre a constituição de um fundo de estabilidade e suas fontes de recursos. 
Voltando aos seguros de receita e de produtividades norte-americanos, foi necessário saber se os mercados futuros e de opções podem diminuir o risco de seguradoras e resseguradoras.

Desde a diminuição do volume de fornecimento de crédito rural formal brasileiro, em meados dos anos 80 , iniciou-se o desenvolvimento de um sistema privado de financiamentos que evoluiu para títulos como a Cédula de Produto Rural, cuja característica é distribuir as responsabilidades entre diversos setores especializados em cada operação do título. Segundo setores da produção, a taxa de aval cobrada pelo banco, que pode chegar a $6 \%$ ao ano, inviabiliza um maior volume de negociação da CPR. Sabe-se que um seguro rural relacionado a determinadas mercadorias pode oferecer a mesma segurança a níveis menores do que a taxa de aval. Por esses motivos, procurou-se levantar as opiniões sobre este assunto.

Como foi citado diversas vezes, o grande problema do seguro rural no Brasil é o baixo nível de interesse tanto do produtor como das companhias seguradoras. Por isso, perguntou-se porque o seguro rural não tem apresentado desempenho satisfatório e o que seria necessário para reverter tal situação.

Através dessas questões, procurou-se abranger a maioria dos problemas dos seguros rurais enfrentados no país, esperando-se que as respostas à pesquisa possam apresentar valiosas contribuições e propostas. 


\section{Resultados e Discussão}

Foram enviados 46 questionários no final de novembro de 1997 e retornaram, durante $o$ mês de dezembro, 30 respostas. A distribuição das respostas foi a seguinte: setor de produção, 6 (20\%); setor de comercialização, 6 (20\%); setor financeiro, 6 $(20 \%)$; setor de seguros rurais, $8(26,7 \%)$; setor de processamento, $4(13,3 \%)$. Devese salientar que alguns indivíduos pesquisados participam através de suas empresas em mais de um setor, sendo suas opiniōes relacionadas ao de maior representatividade entre aqueles em que atua.

A seguir, serão apresentados os resultados de cada questão, procurando-se discutir as respostas por setores, quando houver evidências de posições distintas assumidas em bloco. Para maior facilidade de leitura, quando necessário, será reproduzida a pergunta integral na parte superior da tabela, com os posteriores resultados que puderam ser compilados. $A$ íntegra do questionário pode ser vista no Apêndice.

A primeira pergunta foi dividida em três partes e está relacionada ao parâmetro que deve ser utilizado para se calcular a cobertura de um seguro rural.

A Tabela 14 ilustra as respostas dos entrevistados, podendo-se observar que $16,7 \%$ escolheram a receita esperada, $30,0 \%$, a receita histórica e $53,3 \%$, o custo de produção. Nota-se que o setor de seguros, habituado a assumir os riscos de produção, determinou o resultado escolhendo em conjunto o custo de produção. 
Tabela 14. Cobertura ao se Utilizarem Recursos Próprios.

1.1. O seguro rural deverá efetuar a cobertura referente:

$\Rightarrow$ No caso de o produtor utilizar recursos próprios no empreendimento

( ) à receita esperada (produtividade estimada ou histórica $x$ preço futuro);

( ) à receita histórica (produtividade estimada ou histórica $x$ preço histórico);

( ) ao valor do custo de produção estimado.

Comentários:

\begin{tabular}{ccccccccc}
\hline & \multicolumn{4}{c}{ SETORES * } & \multicolumn{2}{c}{ TOTAL } \\
\cline { 2 - 7 } & prod. & com. & finan. & seg. & proc. & no & $(\%)$ \\
\hline Receita esperada & 1 & 2 & 2 & - & - & 5 & 16,7 \\
Receita histórica & 2 & 3 & 2 & - & 2 & 9 & 30,0 \\
Custo de produção & 3 & 1 & 2 & 8 & 2 & 16 & 53,3 \\
\hline
\end{tabular}

Fonte: Dados da pesquisa

* Setores de prod. = produção; com. = comercialização; finan. = financeiro; seg. = seguros; proc. $=$ processamento.

Nos comentários, os que responderam custo de produção argumentaram que, pela dificuldade em se determinarem preços antecipadamente, poderia haver muita especulação quando fossem estabelecer o valor da cobertura. Os que escolheram receita histórica argumentaram sobre o aspecto da estabilidade do produtor rural, ou seja, no caso de quebra de produção, haveria a garantia da renda histórica, o que não geraria descapitalização e não comprometeria resultados futuros. Nota-se que poucos responderam receita esperada, talvez porque inclui outros instrumentos que seriam proteções através dos mercados futuros e de opções.

Em alguns modelos norte-americanos apresentados no capítulo 5, as coberturas referem-se à receita esperada, baseada nas cotações futuras negociadas nas bolsas de futuros.

A segunda parte da primeira pergunta desejou investigar a cobertura na hipótese de o produtor utilizar recursos de crédito rural. As respostas sobre a cobertura em relação ao custo de produção ou receita histórica aproximaram-se $(36,7 \%$ e 33,3\%, respectivamente), mostrando um equilíbrio de opiniões (Tabela 15). Os que 
escolheram receita histórica e emitiram opinião seguiram os mesmos argumentos de estabilidade e descapitalização do produtor rural.

Tabela 15. Cobertura ao se Utilizarem Recursos de Crédito Rural.

1.2. O seguro rural deverá efetuar a cobertura referente:

$\Rightarrow$ No caso de utilização de recursos de crédito rural

( ) à receita esperada, custodiada no banco credor;

( ) à receita histórica, custodiada no banco credor;

( ) ao valor do custo de produção estimado, custodiado no banco;

( ) ao valor do saldo devedor, cujo beneficiário seria o banco.

Comentários:

\begin{tabular}{ccccccccc}
\hline & \multicolumn{4}{c}{ SETORES * $^{*}$} & \multicolumn{2}{c}{ TOTAL } \\
\cline { 2 - 7 } & prod. & com. & finan. & seg. & proc. & no $^{\circ}$ & $(\%)$ \\
\hline $\begin{array}{c}\text { Receita esperada, custodiada } \\
\text { no banco credor }\end{array}$ & 1 & 1 & 2 & 1 & - & 5 & 16,7 \\
$\begin{array}{c}\text { Receita histórica, custodiada no } \\
\text { banco credor }\end{array}$ & 2 & 4 & 2 & - & 2 & 10 & 33,3 \\
$\begin{array}{c}\text { Custo de produção, custodiado } \\
\text { no banco credor }\end{array}$ & 2 & - & 2 & 6 & 1 & 11 & 36,7 \\
$\begin{array}{c}\text { Saldo devedor, cujo beneficiárion } \\
\text { seria o banco }\end{array}$ & 1 & 1 & - & 1 & 1 & 4 & 13,3 \\
\hline
\end{tabular}

Fonte: Dados da pesquisa

* Setores de prod. = produção; com. = comercialização; finan. = financeiro; seg. = seguros; proc. $=$ processamento.

Foi observado que a alternativa de cobertura relacionada ao saldo devedor, tendo o banco como beneficiário, equivale ao Proagro hoje e que, muitas vezes, o saldo devedor do banco não cobre o custo real de produção, visto que os recursos financiados pelo crédito rural formal representam valores abaixo do custo de produção real. Nesse caso, apenas o banco estaria garantido.

A terceira parte da primeira pergunta mostra, na Tabela 16 , que $73,3 \%$ do universo pesquisado consideraram que a indenização deve ser realizada baseando-se na quantidade de produto contratada, em espécie e em benefício do financiador. Ou seja, quando o produtor se utiliza de adiantamento de recursos, através de uma venda 
a termo, por exemplo CPR, a grande parte dos indivíduos pesquisados $(73,3 \%)$ respondeu que o seguro deveria efetuar a indenização em espécie, adquirindo produto no mercado, entregando-o ao agente financiador. Essa alternativa, embora legítima e correta, deverá levar as companhias de seguros a se protegerem contra uma eventual alta de preços do produto para a época de liqüidação do contrato, isto é, caso haja uma seca nas plantações e os produtores não entreguem o produto contratado, a seguradora precisará adquiri-lo no mercado. Entretanto, se o preço de mercado nessa época estiver muito elevado, a companhia de seguros sofrerá prejuízos acima do planejado. Nesse caso, podem-se estudar alternativas de utilização dos mercados futuros e de opções.

Tabela 16. Cobertura ao se Utilizar Adiantamento de Recursos através de um Contrato a Termo.

1.3. O seguro rural deverá efetuar a cobertura referente:

$\Rightarrow$ No caso de o produtor realizar um contrato a termo com adiantamento de recursos, por exemplo: CPR, soja verde, troca insumo por produto etc.

( ) ao valor corrigido do financiamento, cujo beneficiário é o financiador;

( ) à quantidade de produto contratada com pagamento em espécie ao financiador;

( ) ao risco moral (não-entrega da mercadoria, propositadamente);

Comentários:

\begin{tabular}{|c|c|c|c|c|c|c|c|}
\hline & \multicolumn{5}{|c|}{ SETORES * } & \multicolumn{2}{|c|}{ TOTAL } \\
\hline & prod. & com. & finan. & seg. & proc. & $\mathrm{n}^{\mathrm{o}}$ & $(\%)$ \\
\hline $\begin{array}{c}\text { Valor corrigido do } \\
\text { financiamento, cujo beneficiário } \\
\text { é o financiador }\end{array}$ & 2 & 2 & - & 1 & - & 5 & 16,7 \\
\hline $\begin{array}{c}\text { Quantidade contratada, com a } \\
\text { indenização em espécie para o } \\
\text { financiador }\end{array}$ & 4 & 4 & 4 & 7 & 3 & 22 & 73,3 \\
\hline Risco moral & - & - & 2 & - & 1 & 3 & 10,0 \\
\hline
\end{tabular}

Fonte: Dados da pesquisa

* Setores de prod. = produção; com. = comercialização; finan. = financeiro; seg. = seguros; proc. $=$ processamento.

As sugestões apresentadas indicam que a utilização de um seguro poderia diminuir o custo decorrente do risco da operação, que se igualaria ao custo do seguro, 
tornando os custos totais da operação mais baixos (a questão 13 aborda especificamente esse assunto).

Ainda nessa questão, foi sugerido que a cobertura contra o risco moral poderia ser realizada desde que fosse feito outro contrato específico. Foi citado que a cobertura conjunta contra riscos morais e de produção elevaria demasiadamente as taxas de prêmio, inviabilizando o seguro.

Com relação ao risco moral, deve-se lembrar que os contratos Anec, de venda antecipada e troca insumo por produto, não possuíam sistemas de controle do volume de produto comprometido individualmente pelos produtores. A CPR aprimorou essa questão, prevendo que a operação fosse registrada pela Cetip (Central de Custódia e de Liqüidação Financeira de Títulos Privados) que através do CPF do emitente, controla a porcentagem de comprometimento do produtor, Mas esse controle apenas diminui a possibilidade de ocorrências do risco moral.

Na segunda questão, foi perguntado o nível de cobertura, ou garantia, que o seguro rural deve utilizar. Houve indivíduos que não responderam e outros que optaram por mais de uma cobertura. Pode-se notar na Tabela 17 que, em $90 \%$ dos casos, a cobertura deve garantir entre 80 e 100\% em relação ao objeto do seguro. Quatro pesquisados sugeriram cobertura gradativa de 70 a $100 \%$, com prêmios diferentes e de acordo com a escolha do produtor. 
Tabela 17. Porcentagens de Cobertura

\begin{tabular}{ccccccccc}
\hline & \multicolumn{4}{c}{ SETORES * } & \multicolumn{2}{c}{ TOTAL } \\
\cline { 2 - 7 } & prod. & com. & finan. & seg. & proc. & no $^{*}$ & $(\%)$ \\
\hline 100 & 4 & 3 & 5 & 2 & 2 & 16 & 53,3 \\
90 & 1 & - & - & - & - & 1 & 3,3 \\
80 & 2 & 3 & 1 & 2 & 2 & 10 & 33,3 \\
70 & 1 & - & 1 & - & - & 2 & 6,7 \\
Outros & - & - & - & 1 & - & 1 & 3,3 \\
\hline
\end{tabular}

Fonte: Dados da pesquisa

* Setores de prod. = produção; com. = comercialização; finan. = financeiro; seg. = seguros; proc. $=$ processamento .

A porcentagem da cobertura pode variar de acordo com o risco de cada região e cultura, sendo difícil generalizar uma única faixa satisfatória para o mercado segurador e para o produtor.

Quanto à porcentagem da taxa de prêmio em relação ao valor segurado, considerada aceitável para os produtores rurais, $24,1 \%$ responderam que os prêmios devem ser variáveis, visto que estão relacionados ao zoneamento agrícola, tipo de cultura, nível de tecnologia etc. (Tabela 18). Entretanto, $41,3 \%$ acreditam que níveis de prêmio em torno de 4 a $5 \%$ seriam aceitáveis. Dois entrevistados ligados ao setor de produção e um ao setor de seguros observaram que produtores poderiam arcar com prêmios de até 2 ou $3 \%$ e que, caso os cálculos atuariais apresentassem valores mais elevados, seria necessária uma linha de subsídios do governo federal. Houve também sugestão de aplicar uma franquia dedutível para diminuir a taxa de prêmio. 
Tabela 18. Porcentagens de Prêmios

\begin{tabular}{cccccccc}
\hline & \multicolumn{4}{c}{ SETORES * } & \multicolumn{2}{c}{ TOTAL } \\
\cline { 2 - 6 } & prod. & com. & finan. & seg. & proc. & no & $(\%)$ \\
\hline $2 \%$ & 3 & 1 & - & 1 & - & 5 & 17,2 \\
$3 \%$ & 1 & - & 1 & - & - & 2 & 6,9 \\
$4 \%$ & 2 & - & 2 & - & - & 3 & 10,3 \\
$5 \%$ & 2 & 3 & 1 & 1 & 2 & 9 & 31,0 \\
$6 \%$ & - & - & - & - & 1 & 1 & 3,4 \\
Acima de 6\% & - & 1 & - & 1 & - & 2 & 6,9 \\
Variável & & & & & & 7 & 24,1 \\
\hline
\end{tabular}

Fonte: Dados da pesquisa

* Setores de prod. = produção; com. = comercialização; finan. = financeiro; seg. = seguros; proc. $=$ processamento.

Os principais tipos de sinistros que o seguro rural deveria cobrir também foram perguntados na questão 4 . Segundo $89,2 \%$ das respostas, todos os eventos causadores de perdas e pragas e doenças sem controles conhecidos deveriam ser cobertos (Tabela 19). Dois indivíduos pesquisados observaram que a definição dos sinistros a serem cobertos depende de estudos sobre a ocorrência dos mesmos, o que se aproxima do conceito de zoneamento climático. O setor de seguros afirmou que é mais fácil administrar seguros rurais mais abrangentes, que cubram a maioria dos eventos causadores de perdas. 


\begin{tabular}{|c|c|c|c|c|c|c|c|}
\hline & \multicolumn{5}{|c|}{ SETORES * } & \multicolumn{2}{|c|}{ TOTAL } \\
\hline & prod. & com. & finan. & seg. & proc. & $\mathrm{n}^{\mathbf{o}}$ & (\%) \\
\hline $\begin{array}{l}\text { Intempéries climáticas em geral } \\
\text { (chuva, granizo, geada, seca, } \\
\text { vendaval, tromba d'água, enchente) }\end{array}$ & 6 & 6 & 6 & 5 & 4 & 27 & 73,0 \\
\hline $\begin{array}{l}\text { Doenças/pragas sem controle } \\
\text { definido }\end{array}$ & 4 & 2 & - & - & - & 6 & 16,2 \\
\hline Incêndio & 2 & - & - & - & - & 2 & 5,4 \\
\hline Queda de preços & - & - & 2 & - & - & 2 & 5,4 \\
\hline
\end{tabular}

Fonte: Dados da pesquisa

* Setores de prod. = produção; com. = comercialização; finan. = financeiro; seg. = seguros; proc. $=$ processamento .

Ainda nessa questão, dois entrevistados do setor financeiro acham que as companhias de seguros poderiam incluir em suas apólices a cobertura contra o risco de quedas de preços, garantindo assim a renda do produtor. Nota-se a importância dada por alguns indivíduos às oscilações de preços.

Quando perguntados se o seguro rural deve utilizar zoneamento agrícola (questão 5), a opinião dos pesquisados foi unânime, admitindo ser este um instrumento técnico muito importante, devido às extensas fronteiras de produção do país, que deve ser aprimorado para regiões mais restritas. Observaram que os prêmios devem ser diferenciados, com forte incentivo para as determinações do zoneamento. Entretanto, alguns insistem que as pesquisas devem estar intimamente ligadas às áreas técnicas de instituições de pesquisas e de cooperativas. Lembrou-se também que, há menos de uma década, as áreas do cerrado, na região Centro-Oeste, eram impróprias para o cultivo, mas que atualmente, o cerrado do Mato Grosso possui produtividades até mais altas que as do norte do Paraná.

A discussão dessa questão leva à conclusão de que o Proagro deu um importante passo na reestruturação do programa, porque instituiu o zoneamento com épocas de plantio rigorosas e está operando com taxas diferenciadas para os 
produtores que utilizam-no corretamente. Deve-se considerar também que, de acordo com levantamentos da pesquisa, a Cosesp já vem atuando no Estado de São Paulo com zoneamento há alguns anos.

No que diz respeito à opinião sobre o papel que devem desempenhar o Proagro e as seguradoras privadas no Brasil (questão 6), as respostas apresentaram opiniões bastante diversas. Algumas delas abordaram somente os problemas do Proagro e não especificaram se as sugestões relacionavam-se ao programa ou às seguradoras. A Tabela 20 procura sintetizar algumas sugestões.

Tabela 20. Papel do Proagro e das Seguradoras

\begin{tabular}{|c|c|c|c|c|c|c|c|c|}
\hline & & \multicolumn{5}{|c|}{ SETORES * } & \multicolumn{2}{|c|}{ TOTAL } \\
\hline & & prod. & com. & finan. & seg. & proc. & $\mathrm{n}^{\circ}$ & $(\%)$ \\
\hline \multirow{3}{*}{$\begin{array}{c}\text { Proagro } \\
e \\
\text { Seguradoras }\end{array}$} & $\begin{array}{c}\text { Amparo à atividade } \\
\text { agrícola }\end{array}$ & 3 & 1 & - & $\overrightarrow{-}$ & 2 & 6 & 21,4 \\
\hline & $\begin{array}{c}\text { Aumentar e aprimorar } \\
\text { a atuação }\end{array}$ & 1 & - & 3 & 1 & 1 & 6 & 21,4 \\
\hline & Remodelar o Proagro & 4 & 3 & 1 & 1 & 1 & 10 & 35,7 \\
\hline \multirow[t]{2}{*}{ Proagro } & $\begin{array}{c}\text { Atuar em regiões e } \\
\text { para produtores } \\
\text { desamparados }\end{array}$ & 1 & - & - & 3 & - & 4 & 14,3 \\
\hline & Extinguir o Proagro & - & 1 & 1 & - & - & 2 & 7,1 \\
\hline
\end{tabular}

Fonte: Dados da pesquisa

* Setores de prod. = produção; com. = comercialização; finan. = financeiro; seg. = seguros; proc. $=$ processamento.

Com relação ao papel do Proagro e das companhias seguradoras, $21,4 \%$ consideraram que deve estar relacionado ao amparo da atividade agropecuária, por serem eles instrumentos de estabilização da renda rural; outros $21,4 \%$ acharam que o setor de seguros rurais deve ser aprimorado, intensificando-se sua atuação. 
Para a sobrevivência do Proagro, 35,7\% levantaram que deve ele reconquistar sua credibilidade, saldando os compromissos pendentes e aprimorando as operações, através de treinamento de inspetores, maior rigor na documentação exigida e apuração de fraudes. Deve passar a ser um seguro para o produtor e não para o banco, garantindo a receita (não foi especificada se histórica ou esperada) e colocando o banco como beneficiário apenas do saldo devedor. Nesse caso, antes de efetuar o financiamento, produtor, banco e Proagro ou seguradora necessitam analisar os preços futuros, o custo de produção e o valor do financiamento, e, somente se as margens permitirem, se efetua o negócio.

O Proagro também deve limitar-se a pequenos produtores, como os clientes do $\operatorname{Pronaf}^{43}$, e a áreas que não possuam companhias seguradoras, reservando-se às seguradoras privadas o atendimento a produtores com maior tecnologia, através de produtos mais sofisticados, de acordo com $14,3 \%$ dos pesquisados.

Foi proposta a criação da obrigatoriedade de todas as companhias de seguros operarem determinado volume de seguros rurais; caso se recusassem, seria necessário efetuarem depósito de determinado valor para o fundo de estabilidade rural. Seria a mesma exigência que o Bacen faz aos bancos comerciais em relação a operações em crédito rural.

Talvez essas sugestões possam iniciar as discussões para estabelecer-se um direcionamento político para o setor de seguros, uma vez que procuram dividir as responsabilidades entre governo e iniciativa privada.

${ }^{43}$ O Programa Nacional de Apoio à Agricultura Familiar (Pronaf) é um programa governamental que oferece crédito subsidiado a pequenos produtores. Foi criado pelo Governo Fernando Henrique Cardoso e, em 1997, contemplou produtores com renda bruta anual de até $\mathrm{R} \$$ $27.000,00$, através do financiamento de até $\mathrm{R} \$ 5.000,00$, a taxas de juros de $6,5 \%$ ao ano, para o cultivo de qualquer produto. 
$\mathrm{Na}$ sétima questão, perguntou-se sobre o grau de comprometimento e as responsabilidades das resseguradoras, tanto públicas como privadas, nacionais e internacionais, no Brasil. Todos entendem serem de grande importância para a estabilidade do mercado segurador, sendo que $47,6 \%$ das respostas compiladas (Tabela 21) consideram que as resseguradoras devem fornecer garantia total às seguradoras, acima de certo limite não-especificado nas mesmas.

Tabela 21. Responsabilidades das Resseguradoras

\begin{tabular}{ccccccccc}
\hline & \multicolumn{4}{c}{ SETORES * } & \multicolumn{2}{c}{ TOTAL } \\
\cline { 2 - 6 } & prod. & com. & finan. & seg. & proc. & no & $(\%)$ \\
\hline $\begin{array}{c}\text { Garantia total das operações acima } \\
\text { de determinado limite }\end{array}$ & 2 & 4 & 1 & 1 & 2 & 10 & 47,6 \\
$\quad \begin{array}{c}\text { Livremente negociadas entre } \\
\text { seguradoras e resseguradoras }\end{array}$ & - & 1 & 2 & 1 & - & 4 & 19,0 \\
$\begin{array}{c}\text { Em torno de 50\% com a atuação do } \\
\text { governo no caso de catástrofes }\end{array}$ & - & - & 2 & 5 & - & 7 & 33,3 \\
\hline
\end{tabular}

Fonte: Dados da pesquisa

* Setores de prod. = produção; com. = comercialização; finan. = financeiro; seg. = seguros; proc. $=$ processamento.

Foi observado em $19 \%$ das respostas que o IRB, é legalmente obrigado a ressegurar todos os tipos de seguros rurais e que, com a abertura do mercado, serão negociadas taxas e responsabilidades entre companhias de seguros e resseguradoras privadas. Mas há necessidade de se regular rigorosamente este mercado para evitar abusos.

Outros $33 \%$ das respostas consideraram que as responsabilidades devem ser em torno de $50 \%$ da resseguradora e $50 \%$ da seguradora, sendo que, em casos de catástrofes, seria necessária a atuação de um lastro governamental.

Sugeriu-se que fosse criado um pool de seguradoras distribuindo cotas de responsabilidades entre elas, que poderiam atuar da mesma forma que uma resseguradora, mas com a denominação de co-seguradoras. 
A oitava questão, sobre as medidas necessárias para inibir as fraudes, foi a que resultou maior participação dos pesquisados no que se refere a idéias e sugestões. De acordo com as respostas compiladas na Tabela 22 , observa-se que quase $85 \%$ consideram a fiscalização e uma gabaritada equipe de técnicos, fatores necessários para inibir fraudes. Outros 15,4\% sugeriram a implantação de um cadastro dos fraudadores com a impossibilidade de operar quaisquer seguro rural e linha de financiamento formal ou de participar de benefícios e subvenções aplicados ao setor rural, além de serem enquadrados como estelionatários na justiça comum.

Tabela 22. Medidas para Inibir Fraudes

\begin{tabular}{ccccccccc}
\hline & \multicolumn{4}{c}{ SETORES * } & \multicolumn{2}{c}{ TOTAL } \\
\cline { 2 - 7 } & prod. & com. & finan. & seg. & proc. & $\mathrm{n}^{\circ}$ & $(\%)$ \\
\hline Fiscalização & 6 & 5 & 4 & 3 & 1 & 19 & 48,7 \\
$\begin{array}{c}\text { Cadastro dos fraudadores e } \\
\text { aplicação de penas rigorosas }\end{array}$ & - & 1 & 3 & - & 2 & 6 & 15,4 \\
Equipe de técnicos gabaritados & 3 & 2 & 4 & 3 & 2 & 14 & 35,9 \\
\hline
\end{tabular}

Fonte: Dados da pesquisa

* Setores de prod. = produção; com. = comercialização; finan. = financeiro; seg. = seguros; proc. $=$ processamento.

Várias sugestões foram apresentadas, como: mudança no processo de fiscalização da propriedade atingida, através de profissionais que não possuam vínculo com a região, e que, por sua vez, seriam inspecionados por profissionais regionais empregados da seguradora; levantamento de informações via satélite; fiscalização rigorosa nas distribuidoras de insumos e nos armazéns gerais; no caso de operações de vendas antecipadas (CPR), as empresas financiadoras contribuiriam com sua estrutura de campo no processo de fiscalização; criação de um banco de dados sobre produtividades médias regionais e emprego de tecnologia pelos produtores.

Outras sugestões interessantes foram: a criação de uma bonificação dada ao técnico fiscalizador (engenheiro agrônomo) e ao produtor pelo resultado positivo do empreendimento, visando-se gerar um maior compromisso na fiscalização e na condução da atividade; criação de uma apólice coletiva de no mínimo cinco segurados, com taxas de prêmios mais atraentes, gerando um compromisso de responsabilidade 
mútua entre eles. Também foi levantada a necessidade de se investir em um programa educativo de longo prazo, com o objetivo de formar as gerações futuras.

A questão seguinte levanta a viabilidade da implementação de sociedades de seguros mútuos ou cooperativas como alternativa para solucionar a escassez de seguros rurais. Os que consideraram viável o desenvolvimento dos seguros mútuos somaram 65\%, como mostrado na Tabela 23. Como detalhado na seção 6.1, existem algumas cooperativas no Brasil que desempenham o papel de seguradoras, principalmente através do rateio das perdas entre os cooperados. Essas mútuas dividem as responsabilidades entre produtores, 0 que facilita $\circ$ processo de fiscalização, além de a taxa de administração e a distribuição de dividendos praticamente não existirem. Em outros países, como EUA e Japão, existe uma quantidade muito grande de associações e cooperativas de seguros mútuos. 
Tabela 23. Implementação de Sociedades de Seguros Mútuos ou Cooperativas

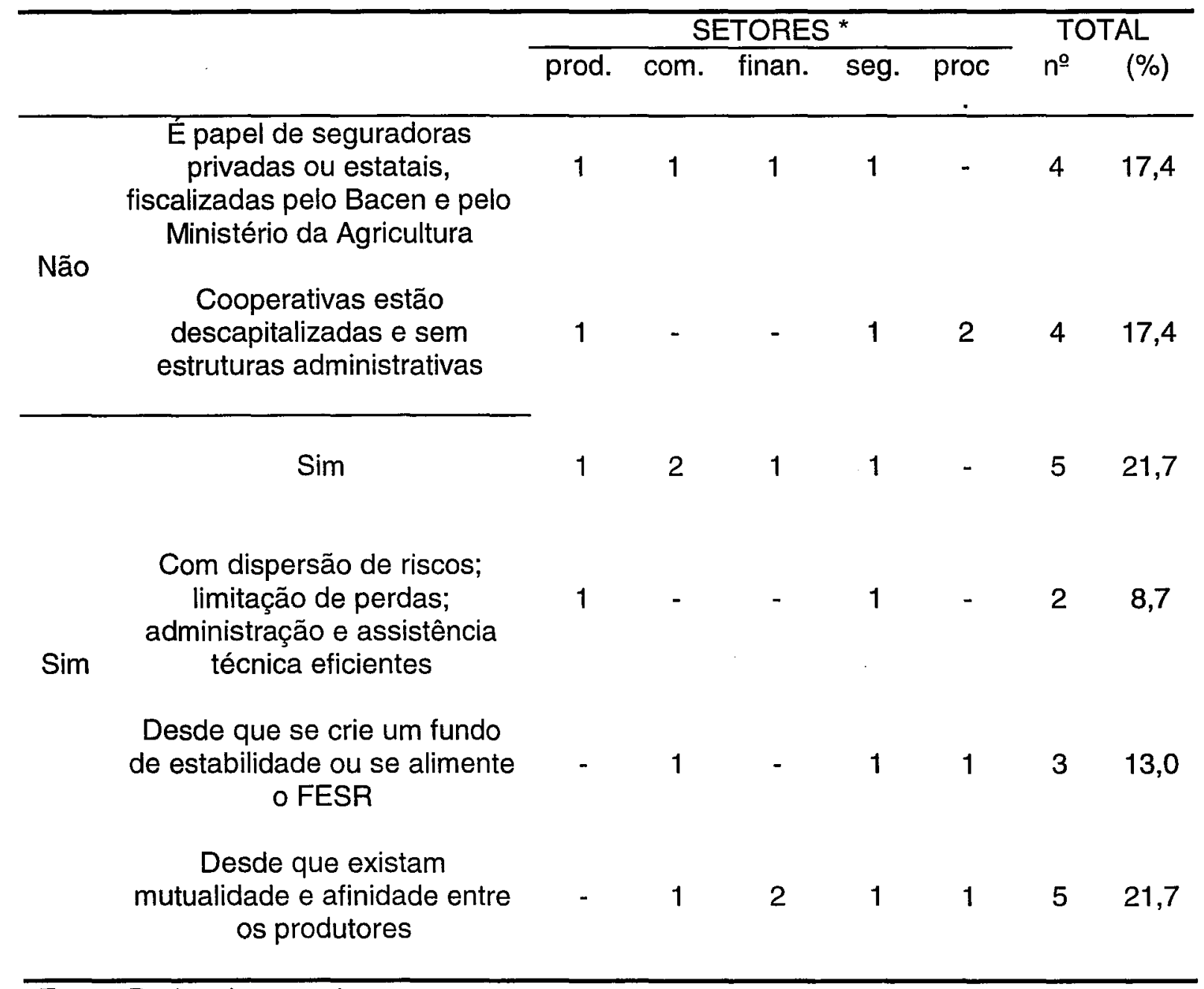

Fonte: Dados da pesquisa

* Setores de prod. = produção; com. = comercialização; finan. = financeiro; seg. = seguros; proc. $=$ processamento.

Os que apoiam apresentaram algumas ressalvas: (a) legislação adequada e fiscalização dos órgãos competentes; (b) criação de um fundo de autoproteção para o caso de catástrofes; (c) fidelidade e comprometimento de todos; (d) estabelecimento de um máximo de risco individual, através de um limite máximo de comprometimento; (e) adequada administração de fundos; (f) assistência técnica de alto nível.

As opiniões desfavoráveis chamam a atenção para a concentração de risco em uma única região, o que pode ser muito perigoso, e levantam a difícil situação administrativa atual da maioria das cooperativas do Brasil. Para as cooperativas e 
associações mútuas poderem operar a contento, necessitariam desenvolver uma estrutura organizacional com profissionais tecnicamente treinados.

Em seguida, perguntou-se se sobre a necessidade de se constituir um fundo de estabilidade sólido para garantir as operações de seguro rural e quais deveriam ser as fontes de recursos.

Com relação à constituição de um fundo de estabilidade para garantia da atividade de seguros, $82 \%$ responderam afirmativamente (Tabela 24 ), desde que fosse utilizado apenas para catástrofes, não fosse administrado pelo governo, tivesse fiscalização do Bacen e não possuísse orientação comercial. Atualmente, o fundo é utilizado de duas maneiras: na ocorrência de catástrofe, quando a companhia de seguros recupera as indenizações pagas nessas ocasiões, e quando a companhia apresenta déficit operacional durante o exercício anual.

Tabela 24. Constituição de um Fundo de Estabilidade

\begin{tabular}{|c|c|c|c|c|c|c|c|c|}
\hline & & \multicolumn{5}{|c|}{ SETORES * } & \multicolumn{2}{|c|}{ TOTAL } \\
\hline & & prod. & com & finan. & seg. & proc & $n^{\circ}$ & $(\%)$ \\
\hline \multicolumn{2}{|r|}{ Não } & 1 & 2 & 2 & - & - & 5 & 17,9 \\
\hline & Sim & 2 & 3 & 1 & 4 & 3 & 13 & 46,4 \\
\hline Sim & $\begin{array}{l}\text { \% do prêmio, União, Estado, } \\
\% \text { dos tributos pagos pelo } \\
\text { setor, \% ITR, produtor, IOF, } \\
\text { recursos do Proagro, \% de } \\
\text { comissões }\end{array}$ & 2 & 1 & 2 & 4 & 1 & 10 & 35,7 \\
\hline \multicolumn{9}{|c|}{$\begin{array}{l}\text { Fonte: Dados da pesquisa } \\
\text { * Setores de prod. = produção; com. = comercialização; finan. = financeiro; seg. = } \\
\text { seguros; proc. = processamento. } \\
\quad \text { As sugestões de fontes de recursos para alimentação do fundo foram as }\end{array}$} \\
\hline
\end{tabular}

(a) Utilização de parte do COFINS e do PIS que o produtor recolhe por ocasião da venda de seu produto, atualmente $2,65 \%$; percentual de alguns dos 
impostos pagos pela agricultura, como ITR; percentual do IOF recolhido em cada apólice de seguro contratada atualmente;

(b) Primeiramente, criar-se-ia a obrigatoriedade de todas as companhias seguradoras privadas operarem em suas carteiras com seguros rurais; caso não houvesse interesse, precisariam depositar certa quantia de recursos para alimentar o fundo;

(c) Redirecionamento de parte dos recursos do Proagro para o fundo.

A questão onze perguntou se os mercados futuros e de opções podem diminuir o risco de seguradoras e resseguradoras. Notou-se que $62,5 \%$ das respostas acreditam que podem ser instrumentos complementares para o mercado segurador; outros já acham que as seguradoras não devem garantir preços (Tabela 25).

Tabela 25. Diminuição de Riscos Utilizando Mercado Futuros e de Opções

\begin{tabular}{|c|c|c|c|c|c|c|c|c|}
\hline & & \multicolumn{5}{|c|}{ SETORES * } & \multicolumn{2}{|c|}{ TOTAL } \\
\hline & & prod. & com. & finan. & seg. & proc & $n^{0}$ & $(\%)$ \\
\hline & Não & - & 2 & - & 1 & - & 3 & 12,5 \\
\hline Não & $\begin{array}{l}\text { Devem assumir apenas riscos } \\
\text { de produção }\end{array}$ & 2 & 1 & - & 2 & 1 & 6 & 25,0 \\
\hline & Sim & 3 & 2 & - & 2 & 2 & 9 & 37,5 \\
\hline Sim & $\begin{array}{l}\text { Utilizando contratos de } \\
\text { produtividade, futuros e de } \\
\text { opções }\end{array}$ & - & - & 5 & - & 1 & 6 & 25,0 \\
\hline
\end{tabular}

Como pode ser visto no capítulo 5 , referente aos seguros norte-americanos, e na seção 6.3, referente aos modelos baseados nos mercados futuros e de opções, a 
tendência de desenvolvimento de instrumentos de proteção via expectativas futuras vem crescendo de importância, o que deverá gerar novos produtos para o mercado segurador.

Esse tema é muito controverso e talvez um dos mais importantes para discussões posteriores, uma vez que preços e quantidades produzidas guardam fortes relações econômicas.

Quanto à indagação sobre a necessidade de intervenção governamental, por meio de subvenções, nos seguros agricolas (questão 12), 65,5\% das respostas indicaram não haver tal necessidade, conforme mostrado na Tabela 26. Aqueles favoráveis a intervenção do governo ressaltaram que seria necessária apenas indiretamente, através de apoio financeiro a um fundo contra catástrofes ou por meio de subsídios de parte do valor do prêmio. Sugeriu-se que o governo deve restringir-se à fiscalização e à regulação do mercado segurador.

Dentro dessa ótica de participação mínima do governo nos mercados de seguros, cresce a necessidade da utilização de instrumentos privados de diminuição de riscos, voltando mais uma vez a se considerar o desenvolvimento de mercados alternativos, como os futuros e de opções.

Tabela 26. Necessidade de Intervenção Governamental

\begin{tabular}{|c|c|c|c|c|c|c|c|c|}
\hline & & \multicolumn{5}{|c|}{ SETORES * } & \multicolumn{2}{|c|}{ TOTAL } \\
\hline & & prod. & com. & finan. & seg. & proc. & $\mathrm{n}^{\circ}$ & $(\%)$ \\
\hline & Não & 3 & 5 & 4 & 3 & 4 & 19 & 65,5 \\
\hline & Sim & 2 & - & - & - & - & 2 & 6,9 \\
\hline Sim & $\begin{array}{l}\text { Indiretamente, apoiando um } \\
\text { fundo contra catástrofes ou } \\
\text { subsidiando parte do prêmio }\end{array}$ & 1 & 1 & 2 & 4 & - & 8 & 27,6 \\
\hline
\end{tabular}


A décima terceira questão levanta se um seguro rural acoplado à CRP poderia diminuir ou substituir a taxa de aval do banco e, conseqüentemente, o custo de emissão do título. Com a intensificação das emissões de títulos de venda antecipada como a CPR, tem crescido o risco do banco avalista na ocorrência de eventos generalizados, uma vez que, se o produtor não entregar a produção, o banco necessariamente liqüidará a posição devedora em espécie, junto ao comprador.

Quase a totalidade das respostas, $96,2 \%$, considerou que um seguro rural na CPR poderia diminuir a taxa de aval cobrada pelo banco (Tabela 27), aumentando o volume de emissão e, conseqüentemente, a liqüidez do mercado, mas com riscos reduzidos.

Tabela 27. Seguro Acoplado à CPR

\begin{tabular}{ccccccccc}
\hline & \multicolumn{4}{c}{ SETORES * $^{*}$} & \multicolumn{3}{c}{ TOTAL } \\
\cline { 2 - 9 } & prod. & com. & finan. & seg. & proc. & $\mathrm{n}^{\mathrm{o}}$ & $(\%)$ \\
\hline Não & - & 1 & - & - & - & 1 & 3,7 \\
Sim & 5 & 5 & 4 & 8 & 4 & 26 & 96,2 \\
\hline
\end{tabular}

Fonte: Dados da pesquisa

* Setores de prod. = produção; com. = comercialização; finan. = financeiro; seg. = seguros; proc. $=$ processamento.

Deve-se salientar que qualquer instituição, seguradora ou não, que assuma o risco de entregar produto para a empresa que detém a CPR, necessita proteger-se contra oscilações contrárias que o produto poderia sofrer em um cenário de escassez.

Nas duas últimas questões (14 e 15) procurou-se buscar o desenvolvimento livre de idéias referentes ao insucesso dos seguros rurais no Brasil e o que seria necessário para desenvolvê-los. Várias foram as causas apontadas para o fraco desempenho (Tabela 28), sendo elas:

(a) Fraudes: citadas em $26,7 \%$ das respostas. Muitos atribuíram-nas à falta de consciência do produtor em relação ao benefício propiciado por um seguro e à idéia de que, com a fraude, o produtor não prejudicaria ninguém, apenas o governo; 
(b) Prêmios elevados: foram citados em $16,7 \%$ das respostas. Pode-se inferir que o elevado valor de prêmio, conjuntamente com a possibilidade de o Proagro atrasar o pagamento da indenização, retirou do sistema produtores com menores riscos, justamente o segmento mais importante em um sistema de pulverização de riscos;

(c) Tecnologia: a diversidade da tecnologia empregada também dificulta o processo de análise de risco da cobertura, favorecendo o desvio de produção. Ainda dentro da discussão sobre tecnologia, apontou-se a falta de zoneamento agrícola;

(d) Gestão inadequada: foi levantada como desfavorável ao desempenho dos seguros rurais. Podem-se observar, nas subseções 4.2.1 e 4.2.2, algumas evidências de gestões inadequadas nas administrações passadas da Cosesp e do Proagro. Além do mais, o seguro rural foi quase sempre operado por seguradoras estaduais, muitas vezes utilizando critérios mais políticos e sociais do que comerciais.

Tabela 28. Desempenho Não-Satisfatório dos Seguros Rurais

\begin{tabular}{ccc}
\hline & \multicolumn{2}{c}{ SETORES } \\
\hline Fraudes & 8 & $26,7 \%$ \\
Elevados custos dos prêmios & 5 & $16,7 \%$ \\
Baixo desenvolvimento tecnológico & 3 & $10,0 \%$ \\
Gestão inadequada & 3 & $10,0 \%$ \\
Seriedade na fiscalização & 2 & $6,7 \%$ \\
Falta de credibilidade & 2 & $6,7 \%$ \\
Outros & 7 & $23,3 \%$ \\
\hline
\end{tabular}

Fonte: Dados da pesquisa

Também foram identificados alguns pontos gerais como:

- fiscalizações e vistorias falhas, muitas vezes com a conivência da rede de peritos que serviam ao programa; 
- falta de pagamento do Proagro aos segurados, devido aos déficits do programa e à situação de insolvência que o governo federal atravessou no início dos anos 90;

- mercado fechado para operadoras internacionais;

- falta de critérios administrativos na gestão do FESR.

Pelo resumo das opiniões apresentadas nos questionários, estes são os principais fatores do fraco desempenho do mercado de seguros rurais no país. Para o desenvolvimento ou a recuperação desse mercado também foram citadas diversas sugestões, resumidas na Tabela 28.

Tabela 29. O que Seria Necessário para o Desenvolvimento do Mercado Segurador

\begin{tabular}{ccc}
\hline & \multicolumn{2}{c}{ SETORES } \\
\hline Aprimorar a fiscalização & 8 & $33,3 \%$ \\
Programa de educação & 5 & $20,8 \%$ \\
Efetuar mudanças contratuais & 3 & $12,5 \%$ \\
Realizar estudos atuariais & 3 & $12,5 \%$ \\
Outros & 5 & $20,8 \%$ \\
\hline
\end{tabular}

Fonte: Dados da pesquisa

(a) Fiscalização séria e intensiva: sugestão citada por 33,3\% das respostas (Tabela 29). Nota-se que a fiscalização está intimamente relacionada ao processo de fraudes, levantado como desestabilizador em $26,7 \%$ das respostas (Tabela 28);

(b) Educação: o desenvolvimento de trabalhos educativos direcionados aos produtores obteve $20,8 \%$ das respostas;

Outras contribuições:

- levantou-se a necessidade de se aprimorarem as relações contratuais entre os agentes envolvidos; 
- necessidade de estudos estatísticos, incluindo também pesquisas de zoneamento;

- necessidade da criação de um pool de seguradoras associadas às resseguradoras internacionais;

- estabelecimento da moralização do seguro rural, mediante criação de leis mais rigorosas, tanto no caso de fraudes de produtores como em relação à fiscalização;

- as fontes de recursos para operacionalizar o sistema de seguros rurais devem vir da própria fonte produtiva, com todos os riscos que isso implica;

- deve-se criar um linha de subvenção de parte da taxa de prêmio cobrada pela seguradora.

Finalmente, esse questionário conseguiu levantar diversas opiniōes e sugestões dos setores consultados, referentes aos principais pontos que envolvem os seguros rurais brasileiros.

Deve-se salientar a extrema cordialidade com que os pesquisados se dispuseram a respondê-lo, mesmo sabendo que exigiria certo grau de dedicação, devido às características da pesquisa. 


\section{CONCLUSÕES}

Diante da constatação de que os produtores rurais brasileiros vêm diminuindo significativamente a contratação de seguros rurais, conclui-se que podem ser desenvolvidos modelos alternativos e instrumentos potenciais eficientes para elevar a atratividade dos seguros rurais.

Essa conclusão geral baseia-se no estudo dos modelos de cobertura de receitas e de opcões de produtividade utilizados nos EUA e nos dados fornecidos pela pesquisa dirigida.

Por apresentar questões específicas aos agentes de diversos setores, a pesquisa dirigida forneceu dados importantes relacionados a coberturas sobre receitas, rumos do seguro nacional, viabilidade de modelos alternativos, bem como idéias e opiniões para o desenvolvimento do mercado de seguros rurais no país.

A seguir, serão apresentadas as conclusões específicas, procurando-se sempre atender ao problema central.

1) Através da pesquisa, observa-se que coberturas de receitas podem representar uma importante mudança no conceito de seguros rurais, ou seja, a possibilidade de as companhias de seguros poderem efetuar suas coberturas baseadas na receita esperada do produtor rural, embora a minoria dos entrevistados tenha apoiado essa idéia. Através do estudo dos modelos norte-americanos, nota-se também uma clara preocupação em se garantir, por intermédio dos seguros rurais, a receita dos produtores daquele país. Pode-se considerar que esse movimento representa uma forte tendência que deverá materializar-se nos próximos anos. 
Atualmente, tanto o Proagro quanto a Cosesp cobrem valores relacionados ao custo de produção. Evidentemente, quanto maior o risco da seguradora, maior 0 prêmio cobrado.

Se a seguradora assumir a responsabilidade de cobrir receitas, a taxa de prêmio se elevará, devido aos riscos da operação. Entretanto, a um custo mais baixo, a seguradora poderia oferecer um produto intermediário, baseado na cobertura tradicional sobre o custo de produção e na compra de contratos de opção de compra nos mercados de opções. No caso de indenização, se o preço caísse abaixo do custo de produção, o segurado receberia a cobertura referente ao custo de produção, mas, caso o preço subisse, receberia um acréscimo correspondente à elevação do preço, somado à indenização. Isso porque, quando a seguradora compra contratos de opções de compra, ela tem o direito de comprar a mercadoria ao preço contratado, mesmo que seu valor esteja mais alto, repassando assim a diferença.

Em uma primeira análise, pode-se imaginar que 0 valor do prêmio inviabilizaria a operação, porque, na CBOT, uma opção de compra de soja a um preço de vencimento pouco acima do preço futuro custaria em torno de $2,7 \%$ do valor do preço da opção. Acrescidos aos $5 \%$ cobrados em um seguro de produção tradicional, poderia ser um montante extremamente alto. Mas esse raciocínio não está correto, porque as indenizações aconteceriam em média, somente em relação ao risco que a companhia assumiu e não ao valor global.

Isso posto, a seguradora compraria contratos de opção de compra apenas relacionados aos riscos que assumiu e, desse modo, garantiria uma indenização no intervalo entre o custo de produção (valor mínimo, se o mercado cedesse) e pouco abaixo do preço de mercado (se o mercado subisse). Numericamente, a seguradora pagaria prêmios de $2,7 \%$ do valor da opção apenas sobre seu risco assumido, $5 \%$ sobre o custo de produção, o que equivaleria a um prêmio total de $5,135 \%$ ao segurado. 
Seguindo este raciocínio, e aprimorando as estratégias, pode-se imaginar que, se os mercados futuros e de opções se desenvolverem no Brasil, esse tipo de seguro poderia atrair muitos produtores, contribuindo para alterar o perfil do seguro rural no país. Deve-se salientar que esses mercados não negociam todo tipo de mercadorias, sendo que, no Brasil, apenas as opções de café possuem liqüidez que permite negociações.

2) A pesquisa levantou também a possibilidade de, ao associar um seguro agrícola acoplado a uma CPR, tendo como beneficiário a instituição financiadora, a companhia de seguros deveria efetuar a indenização em espécie. Entretanto, a companhia passaria a assumir também o risco de elevação de preços na época da safra, caso tivesse de proceder à indenização. Esse é o risco que o banco avalista corre hoje em dia.

Essa operação de seguro é factível desde que a companhia se posicione no mercado de opções. Ou seja, quando a seguradora estabelece o prêmio a cobrar da empresa compradora da CPR, leva em consideração um determinado preço da mercadoria, no caso de indenização. Para proteger-se contra a elevação desse preço, a seguradora deve comprar contratos de opção de compra.

Desse modo, se, na época da colheita, devido à ocorrência de uma seca generalizada, o preço da mercadoria elevar-se e diversos produtores não entregarem a produção acordada, a companhia exercerá o contrato de opção e, teoricamente, poderá adquirir o produto que vale mais a um preço mais barato, ganhando a diferença.

A diferença recebida na operação em bolsa, acrescida ao valor definido no início da operação através do prêmio arrecadado, constituirá um valor igual ao preço do produto no mercado.

Utilizando um exemplo numérico, considere que uma exportadora de soja tenha adquirido uma CPR de um produtor por $R \$ 14,00 / \mathrm{sc}$ para entrega de 10.000 
sacas de soja em julho, na praça de Ponta Grossa (PR) ${ }^{44}$. Suponha-se que o mercado de opções na Bolsa de Mercadorias e Futuros (BM\&F) tenha liqüidez e que a opção de compra esteja cotada a US\$ $0,378 / \mathrm{sc}$, para uma soja de julho a US $\$ 14,00 / \mathrm{sc}$. Ao mesmo tempo em que a exportadora adquire a CPR, a seguradora compra opções de compra, mas não na mesma quantidade, apenas proporcionalmente a seu risco, uma vez que, em caso de sinistro, estatisticamente, apenas certa porcentagem de perdas ocorrerá (salvo em casos de catástrofes). Se o risco calculado pela seguradora são de $3 \%$, ou seja, 300 sacas ao preço de US\$14,00/sc em julho, ela deve comprar contratos de opções de compra apenas sobre esses 300 sacos, com gastos de US\$ 113,4 .

No caso de indenização, a seguradora repassaria à exportadora recursos suficientes para adquirir os produtos no mercado.

Com essa alternativa, pode-se imaginar que o risco do banco fornecedor do aval diminui consideravelmente, mas ainda existe, principalmente o da não-entrega da mercadoria produzida. Esse risco pode ser dividido com o banco. Imagina-se até uma contribuição mútua entre banco e seguradora em relação a controles e fiscalizações, sendo que cada um poderia dispor de sua estrutura de inspeção, juntando forças e inibindo fraudes.

Mais uma vez, pode-se perceber que os mercados futuros e de opções apresentam alternativas que poderão ser exploradas assim que se desenvolverem.

\footnotetext{
${ }^{44}$ Para calcular este valor, a exportadora trouxe a cotação futura da soja na BM\&F (julho) para o seu valor presente e subtraindo todos os seus custos.
} 
3) As conclusões relacionadas ao Proagro passam primeiramente por uma análise das conseqüências que levaram à situação atual de baixa demanda por seguros rurais. Em meados da década de oitenta, a severa crise financeira que o governo vinha atravessando começou a refletir-se em diversos setores estatais. $O$ crédito rural perdeu o subsídio e os prêmios arrecadados pelo Proagro não retornavam a tempo para o pagamento das indenizações. Esses dois fatores, aliados à ingerência e a problemas técnicos, elevaram o número de fraudes do sistema, ano após ano. Como uma maneira de se proteger, o Proagro elevou suas taxas de prêmios. $O$ processo de não-pagamento, somado à elevação de taxas, expeliu produtores que, ao apresentarem riscos pequenos, não viam vantagem em desembolsar altas taxas e correr o risco de não receber no caso de sinistros. Provavelmente, com a diminuição das operações do Proagro, produtores desenvolveram métodos de administração de riscos mais eficientes (seção 2.3), o que se refletiu na pequena demanda por seguros agrícolas atualmente.

Para reestruturar O Proagro, pode-se oferecer uma cobertura de receita e estabelecer 0 banco como beneficiário até 0 valor financiado. A operacionalização segue a mesma linha adotada nos tópicos (1) e (2).

Mas esse atrativo para aumentar 0 interesse pelo Proagro pode não gerar resultados positivos se não forem tomadas medidas complementares para inibir as fraudes. Talvez uma parte do prêmio deva ser direcionada à estruturação da Receita Federal para coibir fraudes no setor de vendas de insumos e armazenagem. Pode-se propor que parte da taxa destinada pelo banco à assistência técnica privada seja liberada apenas após a colheita, e em caso de sinistro, após a comprovação assinada por um perito. Assim também a criação de uma bonificação dada ao perito, ao engenheiro agrônomo e ao produtor, caso o resultado do empreendimento seja positivo, criando maior compromisso na fiscalização e na condução da cultura. Finalmente, poderia ser criada de uma apólice coletiva de cinco segurados no mínimo, com taxas de prêmios mais atraentes, criando um compromisso de responsabilidade mútua entre eles. 
Todas essas idéias precisam ser apoiadas por um amplo sistema educacional, que envolveria, acima de tudo, a criação do conceito de empresa rural e a administração de riscos.

4) As associações e cooperativas de fundos mútuos poderiam ser uma alternativa para se elevar a utilização de seguros rurais, pela proximidade com 0 produtor. Uma mútua possui um princípio que a diferencia das demais organizações: a ênfase dada ao elemento pessoal, ou seja, sua posição pessoal, seu caráter e sua opinião, representando fatores muito importantes relacionados aos riscos assumidos e pagamentos de perdas rateadas.

O funcionamento de uma cooperativa de seguro mútuo deve, inicialmente obedecer a um padrão de administração independente da cooperativa de produção, possuindo um nível elevado de técnicos em seguros e agrônomos.

Pelo fato de operar em áreas restritas, eleva-se o risco de ocorrência de eventos generalizados. Existem pelo menos quatro maneiras de se administrar esse problema:

- Limitação de riscos cobertos, procurando garantir apenas os empreendimentos contra a ocorrência de eventos que possuam como característica a independência, como por exemplo uma chuva de granizo. Essa limitação fica evidente nos exemplos das curvas de distribuição de freqüência apresentados na subseção 3.2, mostrando que a probabilidade de ocorrência de perdas generalizadas é relativamente pequena;

- Estabelecer um limite da porcentagem máxima de responsabilidade para cada cooperado;

- Procurar efetuar um resseguro no IRB; 
- Procurar diminuir o risco através da atuação em conjunto com uma companhia de seguros.

Se o sistema cooperativista de seguros mútuos crescer, pode-se criar um fundo de estabilidade, entre as cooperativas participantes, para eventos catastróficos.

5) O Fundo de Estabilidade de Seguros Rurais precisa existir e deverá ser rigorosamente fiscalizado. As fontes de recursos precisam ser urgentemente definidas, podendo ser: porcentagem das comissões de corretagem dos seguros de bens públicos; parte do IOF cobrado em cada apólice de seguro; percentual de recolhimento de algum tributo pago pelo setor rural etc.

6) Outra importante conclusão refere-se ao programa de opções de produtividade norte-americano. $O$ programa, embora em fase piloto, possui algumas características desejáveis para o seguro agrícola, visto que não carrega os dois mais importantes riscos rurais, o risco moral e a seleção adversa. Também não tem necessidade de um grande aparato de controle e fiscalização. Deve ser testado no Brasil, com adaptações.

7) Finalmente, este trabalho possibilita algumas conclusões gerais, como:

(a) Em meados de 1997, o Conselho Monetário Nacional autorizou a prorrogação dos débitos da primeira parcela da securitização de alguns produtores atingidos por problemas climatológicos. Caso houvesse um seguro rural que cobrisse a receita desses produtores, talvez a primeira parcela da securitização não tivesse sido prorrogada, mas sim, saldada.

(b) O mercado segurador rural deverá profissionalizar-se nos próximos anos, devido a algumas privatizações ocorridas e em curso, como as da Seguradora União 
do Rio Grande do Sul, comprada pelo Banco Bradesco; da Bemge Seguradora, que está em processo de negociação; do IRB, que também deverá ser privatizado. Embora - Bradesco não opere a área rural da União, diz-se no mercado que está apenas esperando a oportunidade para iniciar os trabalhos. Com relação ao IRB, também poderão ocorrer surpresas positivas, pois será uma resseguradora que, além de possuir técnicos de primeira linha, já tem afinidade com o mercado brasileiro. Mas há a necessidade de se regular rigorosamente esse mercado para evitar abusos.

(c) Notou-se, durante toda a investigação do trabalho, que seguros rurais não fazem parte dos grandes temas de discussão dos vários setores do agribusiness, no qual crédito rural e política de preços possivelmente chamem mais atenção, talvez porque não tenha havido uma grande catástrofe nacional.

8) Como último tópico, deve-se levantar alguns pontos que deixaram de ser abordados e algumas sugestões para futuros trabalhos:

- Aprofundamento das técnicas atuariais modernas;

- Realizar estudos sobre administração de riscos, levantando:

. diversificação das propriedades rurais brasileiras;

. expansão de parte de famílias para zonas de fronteira;

. porcentagem da renda obtida fora da atividade rural.

- Testar a validade de se utilizarem mercados de opções nos seguros de CPR;

- Testar a validade dos modelos de seguro de receita esperada com mercados de opções; 
REFERÊNCIAS BIBLIOGRÁFICAS 


\section{REFERÊNCIAS BIBLIOGRÁFICAS}

ADACHI, V. Senado aprova a queda do monopólio de resseguro. Gazeta Mercantil. São Paulo, 20 de jun. de 1996.

AGRIANUAL - 1997, p. 149-163, 1997.

ASSOCIAÇÃO DOS FUMICULTORES DO BRASIL. Surgimento da AFUBRA. http://www.afubra.com.br (1998).

AZEVEDO, R.R. Proposta de seguro de soja. São Paulo: Gerenseg, 1996. 24 p.

AZEVEDO, R.R. Cadernos de seguros rurais. São Paulo: Gerenseg, 1997. 19 p.

AZEVEDO, R.R.; DOMINGUES, P. Seguro global do agribusiness. São Paulo: Gerenseg, 1995. $56 \mathrm{p}$.

AZEVEDO-FILHO, A.J.B.V. Análise e administração de riscos. Preços Agrícolas, v. 11, n. 34, p. 31, dez. 1997. 
AZEVEDO-FILHO, A.J.B.V.; MARTINES-FILHO, J.G.; ARAÚJO, P.F.C. Alternativas de Mercado para programas governamentais de seguro agrícola e de garantia de preços mínimos. Piracicaba: Esalq, Desr, 1996. 11 p. (Esalq. Desr. Série Estudos, 32).

9. BANCO CENTRAL DO BRASIL Manual de crédito rural. Brasília: Bacen, Cap. 7, seção 8, 1992; seção 1,3,6, 1994; seção 2, 4, 5, 7, 9, 10, 1995.

BARROS, G.A.C. Economia da comercialização agrícola. Piracicaba: Fealq, 1987. $306 \mathrm{p}$.

BRASIL. Ministério da Agricultura, do Abastecimento e da Reforma Agrária. Zoneamento Agrícola: Redução dos Riscos Climáticos na Agricultura. Brasília, 1996.

CAFFAGNI, L.C. Financiamentos formais, alternativos e potenciais para agropecuária. In: CURSO DE COMERCIALIZAÇÃO DE COMMODITIES AGROPECUÁRIAS, $6^{\circ}$, Piracicaba, 1995. Piracicaba: Fealq/Cepea, 1995. p. 23-44.

CHICAGO BOARD OF TRADE Manual de commodities. São Paulo: Promerc, 1985. $390 \mathrm{p}$.

CHICAGO BOARD OF TRADE Crop yield insurance futures and options. Chicago: CBOY Publ. Department, 1995. $8 \mathrm{p}$. 
COBLE, K.H.; KNIGHT, T.O.; POPE, R.D.; WILLIAMS, J.R. An expected - indemnity approach to the measurement of moral hazard in crop insurance. Washington: USDA, 1996. $26 \mathrm{p}$.

COELHO, C.N. O novo seguro agrícola dos Estados Unidos. Revista de Política Agrícola, v. 6, n. 2, p. 10-14, abr./jun. 1997.

COMPANHIA DE SEGUROS DO ESTADO DE SÃO PAULO. Legislação básica. São Paulo, 1995a. 130 p.

COMPANHIA DE SEGUROS DO ESTADO DE SÃO PAULO Relatório anual de 1995. São Paulo, 1995b. $18 \mathrm{p}$.

COOPERATIVA AGROPECUÁRIA BATAVO LTDA. Regulamento do fundo mútuo agrícola. Carambei: Batavo, 1992. $6 \mathrm{p}$.

COOPERATIVA AGROPECUÁRIA BATAVO LTDA. Cálculo e indenização fundo mútuo: soja - 96/97 e participação. Carambeí: Batavo, 1997. 5p

FORTUNA; E. Mercado financeiro. Rio de Janeiro: Qualitymark, 1993. 320 p.

FRIEDMAN, J.P. Dictionary of business terms. New York: Barron's, 1987. $650 \mathrm{p}$. 
GÖPFERT, H.; ROSSETI, L.A.; SOUZA, J. Eventos generalizados e securidade agrícola. Brasília: IPEA, 1993. $91 \mathrm{p}$.

HARWOOD, J.; MIRANDA, M.; MOREHART, M.; DISMUKES, R.; COBLE, K. Federal crop insurance reform: How Does It Work? Agricultural outlook. Washington: USDA, march, 1995. p. 24-30

HOFFMANN, R.; SERRANO, O.; NEVES, E.M.; THAME, A.C.M.; ENGLER, J.J.C. Administração da empresa agrícola. São Paulo: Pioneira, 1976. 323 p.

HULL;, J. Introdução aos mercados futuros e de opções. São Paulo: Bolsa de Mercadorias \& Futuros/Cultura Editores Associados, 1996. 448 p.

INDICADORES DA AGROPECUÁRIA, v. 6, n. 11, p. 13, nov. 1997.

JARMAN, J. Crop insurance handbook. http://www.indy.net/ cropins/types.html (1996).

KMENTA, J. Elementos de econometria. São Paulo: Atlas, 1988. 696 p.

MACHADO, R.R.B. Cédula de Produto Rural - CPR. In: SEMINÁRIO DE NOVAS ESTRATÉGIAS OPERACIONAIS PARA O MERCADO DE AÇÚCAR, Piracicaba, 1995. Piracicaba: Fealq/Cepea, 1995. p. 57-66 
MARQUES, P.V.; MELLO, P.C. Mercados futuros de commodities agropecuárias. Piracicaba: Esalq, Desr, 1997. 176 p. (Esalq. Desr. Séries Didáticas, 114)

MARTINI, S. O seguro do custeio agrícola. São Paulo: Secretaria da Agricultura/COSESP, 1978. $96 \mathrm{p}$.

- MARTINS, S.S. Risco e seguro das atividades agrícolas. São Paulo: IEA, 1985. $72 \mathrm{p}$.

MARTINS, S.S. A extinção do seguro obrigatório da lavoura de algodão no Estado de São Paulo. Informações Econômicas, v. 21, n. 11, p.15-18, nov. 1991.

MENDES, J.T.G. Economia agrícola: princípios básicos e aplicações Curitiba: Scientia et Labor/Editora da UFPR, 1989. 399 p.

MENEGUeTTE, Á. Produzindo sem surpresas. Agroanalysis. v. 17, n. 10, p. 13 , out. 1997.

MIRANDA, M.J.; CLAUBER, J.W. Uninsurable systemic risk and the failure of crop insurance markets: a case for area-yield options. Washington: USDA, 1995. $26 \mathrm{p}$.

ORICOLLI, S. O seguro mútuo como alternativa. Gazeta Mercantil. São Paulo, 18 de novembro de 1996. 
PEREIRA, F.H. Mercado futuro e de opções. In: SEMINÁRIO DE ESTRATÉGIAS OPERACIONAIS PARA OS MERCADOS DE BOI E CAFÉ, São Paulo, 1996, São Paulo: Bolsa de Mercadorias \& Futuros, 1996. p. $76-87$

PINHEIRO, A. Auditoria apura déficit de US $\$ 700$ milhões no Proagro em cinco anos. Gazeta Mercantil São Paulo. 30 de mar. De 1995.

PROGNÓSTICO. São Paulo: Secretaria de Agricultura e Abastecimento/IEA, diversos anos.

*) PROGRAMA DE GARANTIA DA ATIVIDADE AGROPECUÁRIA. Relatório de atividades. Brasília: Comissão Especial de Recursos, 1995. 95 p.

RAY, P.K. Agricultural insurance. Oxford: Pergamon Press, 1981. 411 p.

ROCHA, J. Governo vai quitar dívida atrasada do Proagro. Gazeta Mercantil São Paulo. 19 de junho de 1997.

ROCHA JR., W.F. Suco de laranja concentrado congelado (SLCC) em concessionárias de refeições coletivas (um estudo exploratório). Piracicaba, 1994. 106p. Dissertação (Mestrado) - Escola Superior de Agricultura "Luiz de Queiroz", Universidade de São Paulo.

SANDRONI, P. Dicionário de economia. São Paulo: Editora Best Seller, 1989. 
SÃO PAULO (Estado). Secretaria da Agricultura. Comissão de Produção Agropecuária. Aspectos do seguro agrícola em São Paulo. São Paulo, 1971. $120 \mathrm{p}$.

? SEGURO AGRÍCOLA COSESP Condições gerais, particulares e tarifas. São Paulo: 1996 - 1997.

SELDON, A.; PENNANCE, F.G. Dicionário de economia. Rio de Janeiro: Bloch Editores, 1968.

SKEES, J.R. Market: Based solutions for catastrophic risk in agriculture. University of Kentucky, Department of Farm Management, 1997. $30 \mathrm{p}$.

SOUSA, E.L.L. Estudo do potencial de desenvolvimento de um mercado futuro de milho no Brasil. Piracicaba, 1994. 106 p. Dissertação (Mestrado) - Escola Superior de Agricultura "Luiz de Queiroz", Universidade de São Paulo.

v TARTAROTTI, H.H. Estudo sobre o Programa de Garantia da Atividade Agropecuária - PROAGRO. Brasília: Consultoria Legislativa do Senado Federal, 1995. 10 p. (PROAGRO. Estudo, 51).

VIEIRA, J.L.T.M.; GATTI, E.U. Lei agrícola brasileira: necessidade de reformulação. Informações Econômicas, v. 21, n. 3, p.21-28, mar. 1991.

YOUNG, C.E.; WESTCOTT, P.C. The 1996 U.S. farm act increases market orientation. Washington: USDA, 1996. 24 p. 
APÊNDICE 
Prezado Senhor,

O questionário a seguir faz parte da dissertação de mestrado SEGURO RURAL NO BRASIL: EVOLUÇÃO, ALTERNATIVAS E SUGESTÕES, realizada junto ao Departamento de Economia e Sociologia Rural da Escola Superior de Agricultura "Luiz de Queiroz"/Universidade de São Paulo. Pretendem-se analisar sugestões dos diversos agentes ligados à produção, à comercialização, ao processamento e ao setor de seguros agrícolas, com $\circ$ objetivo de formular propostas para o setor agroindustrial brasileiro.

Após o preenchimento, favor enviar via fax para o número (019) 434-7217. Deve-se salientar que todos os questionários serão tratados com total sigilo e seus resultados divulgados apenas de maneira agregada.

No caso de as respostas ultrapassarem o espaço destinado, utilizar o final do questionário. Caso haja necessidade de as respostas serem complementadas com algum paper ou apostila, favor enviar para o seguinte endereço:

Centro de Estudos Avançados em Economia Aplicada / Fealq A/C Luiz Cláudio Caffagni

Av. Carlos Botelho, 987

13416-145

Piracicaba, SP

Tel.: (019) 433-4499 


\section{DISSERTAÇÃO DE MESTRADO - Esalq/USP}

Seguro Rural: Evolução, Propostas Recentes e Sugestões para o Brasil As Folhas de respostas deverão ser enviadas para o fax (019) 4347217 a/c - Luiz Cláudio Caffagni

Nome:

1. O seguro rural deverá efetuar a cobertura referente:

$\Rightarrow$ No caso de o produtor utilizar recursos próprios no empreendimento

( ) à receita esperada (produtividade estimada ou histórica $x$ preço futuro);

( ) à receita histórica (produtividade estimada ou histórica x preço histórico);

( ) ao valor do custo de produção estimado.

Comentários:

$\Rightarrow$ No caso de utilização de recursos de crédito rural

( ) à receita esperada, custodiada no banco credor;

( ) à receita histórica, custodiada no banco credor;

( ) ao valor do custo de produção estimado, custodiado no banco;

( ) ao valor do saldo devedor, cujo beneficiário seria o banco.

Comentários:

$\Rightarrow$ No caso de o produtor realizar um contrato a termo com adiantamento de recursos, por exemplo: CPR, soja verde, troca insumo por produto etc.

( ) ao valor corrigido do financiamento, cujo beneficiário é o financiador;

( ) à quantidade de produto contratado com pagamento em espécie ao financiador;

( ) ao risco moral (não-entrega da mercadoria, propositadamente).

Comentários:

2. Quais a(s) porcentagem(ns) de cobertura que o seguro rural deve utilizar?

( ) ..\%

Comentários:

3. Para haver aceitação por parte dos produtores rurais, o seguro rural deve possuir um prêmio de até $\%$ do valor segurado.

4. Quais os principais tipos de sinistros que o seguro rural deveria cobrir?

5. O seguro rural deve utilizar zoneamento agrícola?

6. Na sua opinião, qual o papel que deve desempenhar o PROAGRO e as seguradoras privadas no Brasil? 
7. Qual deveria ser o grau de comprometimento e das responsabilidades das resseguradoras, tanto públicas como privadas, nacionais e internacionais, no Brasil?

8. Do seu ponto de vista, quais as medidas necessárias para inibir a fraude no seguro rural?

9. É viável a implementação de sociedades de seguros mútuos ou cooperativas como alternativa para solucionar a escassez de seguros rurais no Brasil? Porque?

10. Há necessidade de se constituir um fundo de estabilidade sólido para garantir as operações de seguro rural no Brasil? Quais deveriam ser as fontes de recursos?

11. Os mercados futuros e de opções podem diminuir o risco de seguradoras e resseguradoras? Como?

12. Há necessidade de intervenção governamental, por meio de subvenções, nos seguros agrícolas no Brasil? Se afirmativo, de que maneira?

13. Um seguro rural acoplado à CRP poderia diminuir ou substituir a taxa de aval do banco e, conseqüentemente, o custo de emissão do título?

14. Na sua opinião, por que os seguros rurais no Brasil não apresentam desempenho satisfatório? $\mathrm{E}$ o que seria necessário no que se refere a fontes de recursos, garantias, salvaguardas, desenho de contratos, educação, fiscalização etc.?

15. Comentários Adicionais: 